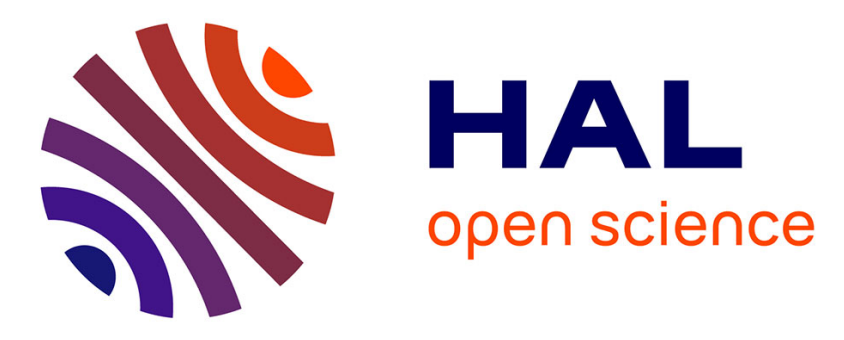

\title{
LGP2 binds to PACT to regulate RIG-I- and MDA5-mediated antiviral responses
}

Raul Sanchez David, Chantal Combredet, Valérie Najburg, Gaël Millot, Guillaume Beauclair, Benno Schwikowski, Thibaut Léger, Jean-Michel Camadro, Yves Jacob, Jacques Bellalou, et al.

\section{To cite this version:}

Raul Sanchez David, Chantal Combredet, Valérie Najburg, Gaël Millot, Guillaume Beauclair, et al.. LGP2 binds to PACT to regulate RIG-I- and MDA5-mediated antiviral responses. Science Signaling, 2019, 12 (601), pp.eaar3993. 10.1126/scisignal.aar3993 . hal-03100138

\section{HAL Id: hal-03100138 \\ https://cnrs.hal.science/hal-03100138}

Submitted on 6 Jan 2021

HAL is a multi-disciplinary open access archive for the deposit and dissemination of scientific research documents, whether they are published or not. The documents may come from teaching and research institutions in France or abroad, or from public or private research centers.
L'archive ouverte pluridisciplinaire HAL, est destinée au dépôt et à la diffusion de documents scientifiques de niveau recherche, publiés ou non, émanant des établissements d'enseignement et de recherche français ou étrangers, des laboratoires publics ou privés. 


\section{LGP2 binds to PACT to regulate RIG-I- and MDA5-mediated antiviral responses}

\author{
Raul Y. Sanchez David ${ }^{1,2 *}{ }^{\dagger}$, Chantal Combredet ${ }^{1 *}$, Valérie Najburg ${ }^{1}$, Gael A. Millot ${ }^{3}$, \\ Guillaume Beauclair ${ }^{1}$, Benno Schwikowski ${ }^{4}$, Thibaut Léger ${ }^{5}$, Jean-Michel Camadro ${ }^{5,6}$, \\ Yves Jacob ${ }^{7}$, Jacques Bellalou ${ }^{8}$, Nolwenn Jouvenet ${ }^{1}$, Frédéric Tangy ${ }^{1 \ddagger}$, Anastassia V. Komarova ${ }^{1 \neq}$
}

\begin{abstract}
The retinoic acid-inducible gene I (RIG-I)-like receptors (RLRs) RIG-I, MDA5, and LGP2 stimulate inflammatory and antiviral responses by sensing nonself RNA molecules produced during viral replication. Here, we investigated how LGP2 regulates the RIG-I- and MDA5-dependent induction of type I interferon (IFN) signaling and showed that LGP2 interacted with different components of the RNA-silencing machinery. We identified a direct proteinprotein interaction between LGP2 and the IFN-inducible, double-stranded RNA binding protein PACT. The LGP2PACT interaction was mediated by the regulatory C-terminal domain of LGP2 and was necessary for inhibiting RIG-I-dependent responses and for amplifying MDA5-dependent responses. We described a point mutation within LGP2 that disrupted the LGP2-PACT interaction and led to the loss of LGP2-mediated regulation of RIG-I and MDA5 signaling. These results suggest a model in which the LGP2-PACT interaction regulates the inflammatory responses mediated by RIG-I and MDA5 and enables the cellular RNA-silencing machinery to coordinate with the innate immune response.
\end{abstract}

\section{INTRODUCTION}

Progress in our understanding of the cellular pathways that control viral replication suggests that modulating host cell functions early upon viral infection could inhibit a large panel of RNA viruses (1-5). The retinoic acid-inducible gene I (RIG-I)-like receptors (RLRs) appear to be located at the frontline of the evolutionary race between viruses and the host immune system (6). This family of pattern recognition receptors is a group of cytosolic RNA helicases that can identify viral RNA as nonself through binding to pathogenassociated molecular patterns. To date, three RLRs have been identified: RIG-I, MDA5 (melanoma differentiation-associated gene 5), and LGP2 (laboratory of genetics and physiology 2) (7, 8). RIG-I and MDA5 share a number of structural similarities, including their organization into three distinct domains: (i) a N-terminal caspase activation and recruitment domain (CARD), (ii) a central $\mathrm{DExD} / \mathrm{H}$ box RNA helicase domain, and (iii) a C-terminal regulatory domain. Upon ligand binding, MDA5 and RIG-I stimulate a signaling cascade through mitochondrial antiviral-signaling protein (MAVS) on mitochondria. MAVS activation leads to the translocation of the transcription factors interferon regulator factor 3 (IRF3) and IRF7 and nuclear factor $\kappa \mathrm{B}(\mathrm{NF}-\kappa \mathrm{B})$ to the nucleus to coordinate the expression of genes encoding the type I interferons (IFNs) and proinflammatory cytokines, which results in the activation of hundreds

\footnotetext{
${ }^{1}$ Unité de Génomique Virale et Vaccination, Institut Pasteur, CNRS UMR-3569, Paris, France. ${ }^{2}$ Ecole doctorale B3MI/Paris7, Paris, France. ${ }^{3} \mathrm{Hub}$ de Bioinformatique et Biostatistique-C3BI, Institut Pasteur, USR 3756 CNRS, Paris, France. ${ }^{4}$ Systems Biology Laboratory and USR 3756, Institut Pasteur and CNRS, Paris, France. ${ }^{5}$ Mass Spectrometry Laboratory, Institut Jacques Monod, UMR 7592, Univ Paris Diderot, CNRS, Sorbonne Paris Cité, F-75205 Paris, France. ${ }^{6}$ Mitochondria, Metals, and Oxidative Stress Group, Institut Jacques Monod, UMR 7592, Université Paris Diderot, CNRS, Sorbonne Paris Cité, F-75205 Paris, France. ${ }^{7}$ Unité de Génétique Moléculaire des Virus à ARN, Institut Pasteur, Paris, France. ${ }^{8}$ Platform of Recombinant Proteins in Prokaryotic Cells, Institut Pasteur, 75015, CNRS UMR 3528, Paris, France. *These authors contributed equally to this work.

tPresent address: Section of Virology, Department of Medicine, Imperial College London, London, UK.

‡Corresponding author. Email: frederic.tangy@pasteur.fr (F.T.); stasy@pasteur.fr (A.V.K.)
}

of IFN-stimulated genes (ISGs) (7). The RLR response is required to initiate an antiviral state and to orchestrate the inflammatory response in the infected tissue.

Unlike RIG-I and MDA5, LGP2 lacks a CARD domain. It is involved in regulating the activities of MDA5 and RIG-I (9). LGP2 synergizes with MDA5 to increase the specific antiviral response, possibly through increasing the ability of MDA5 to form stable filaments on short double-stranded RNA (dsRNA), thus amplifying its signaling activity (10). In picornavirus and paramyxovirus infections, MDA5-specific RNA ligands have been shown to interact with LGP2 $(11,12)$. In addition, LGP2 knockout cells have a reduced type I IFN response to picornaviruses ex vivo and in vivo (13).

Ex vivo studies have shown that ectopic expression of LGP2 or of the LGP2 C-terminal domain (CTD) alone leads to loss of the RIG-I-mediated type I IFN response $(14,15)$. It was first suggested that because LGP2 has a higher affinity for dsRNA than that of RIG-I, it could sequester viral dsRNA, thus preventing RIG-I from recognizing its ligand (16). However, a mutated LGP2 deficient in RNA binding can still inhibit RIG-I signaling (17). Furthermore, it was described that the LGP2 CTD could bind to the RIG-I CTD to inhibit recognition of the viral ligand (15), although this interaction has not been observed by others $(18,19)$. A third model was proposed in which the interaction between LGP2 and MAVS could be responsible for inhibiting the activation of the signaling cascade (9). However, this hypothesis is contradictory with the fact that LGP2 amplifies the MDA5 response, which shares a common signaling cascade with RIG-I.

In vivo studies have increased the controversy about the mechanism by which LGP2 inhibits the RIG-I response. Consistent with ex vivo models, LGP2 knockout mice developed by Venkataraman et al. (13) exhibit an increased inflammatory response to viruses recognized by RIG-I . However, other in vivo studies with LGP2 knockout mice reported the opposite effect $(20,21)$. Last, mouse models that overexpressed human LGP2 demonstrated a reduction of the type I IFN response while presenting reduced viral fitness $(22,23)$. To better understand the mechanism of regulation of the RLR-mediated 
antiviral response by LGP2, we investigated the LGP2 protein network through a previously validated high-throughput proteomic approach (24). Among the LGP2-binding partners that we identified, we focused on RNA-silencing machinery components, particularly on the IFN-inducible dsRNA-dependent protein kinase activator A (PACT) and its effect on the regulation of RIG-I- and MDA5dependent antiviral responses by LGP2.

\section{RESULTS \\ LGP2 overexpression enhances MDA5- and blocks RIG-I-mediated IFN- $\beta$ promoter signaling}

We previously generated a human embryonic kidney-293 (HEK293) cell line stably expressing One-STrEP-tagged LGP2 (hereafter referred to as ST-LGP2; Fig. 1A) and validated the ability of the N-terminally tagged LGP2 to interact with LGP2-specific viral RNA ligands (12). This cell line had 10,000-fold more LGP2 mRNA copies than did standard HEK293 cells (12). First, we analyzed the functional profile of ST-LGP2 cells transfected with synthetic agonists of RIG-I and MDA5. Luciferase (Luc) reporter assays were used to evaluate the IFNB1 (which encodes IFN- $\beta$ ) and $N F-\kappa B$ promoter activities in cells transfected with in vitro-transcribed $5^{\prime}$-triphosphate RNA (5'3P-RNA) and low-molecular weight (LMW) poly(I:C), which are commonly used to stimulate a RIG-I response $(25,26)$, or with highmolecular weight (HMW) poly(I:C), which specifically triggers MDA5 signaling (26). We observed that, compared to transfection of the parental HEK293 cells, transfection of ST-LGP2 cells with 5'3P-RNA resulted in a statistically significantly reduced IFNB1 promoter activity, whereas transfection with synthetic HMW poly(I:C) statistically significantly increased IFNB1 promoter activity (Fig. 1B). Unexpectedly, transfection of the ST-LGP2 cells with LMW (which is typically a RIG-I agonist) also statistically significantly increased IFNB1 promoter activity (Fig. 1B). This could be explained by the ability of MDA5 to form stable filaments on short dsRNA in the presence of LGP2 (10). A similar profile was observed in ST-LGP2 cells expressing the NF- $\kappa \mathrm{B}$ promoter activation upon transfection with either 5'3P-RNA or HMW poly(I:C) (Fig. 1C). These observations confirm previous studies showing that the overexpression of LGP2 synergizes with the type I IFN response upon activation with MDA5-specific agonists, such as HMW poly(I:C) (27), but antagonizes signaling of the RIG-I-specific ligand 5'3P-RNA (14).

Similarly to synthetic ligands, viral infections directly activate RLRs and trigger a type I IFN response. Paramyxovirus infection generates RIG-I-specific RNA ligands that trigger the type I IFN response $(12,28,29)$, whereas picornavirus infection activates LGP2 and MDA5 $(11,13,20,30-32)$. Thus, we analyzed the type I IFN response to viral RNA in ST-LGP2 cells (Fig. 1D). HeLa cells were infected at a multiplicity of infection (MOI) of 1 with the negativesense RNA virus Measles virus (MV; family, Paramyxoviridae) or with the positive-sense RNA viruses Mengovirus (Mengo; family, Picornaviridae; genus, Cardiovirus) and Coxsackie virus (Cox; family, Picornaviridae; genus, Enterovirus). For the two picornaviruses, infections were performed in the presence or absence of the nucleoside analog ribavirin $(1 \mathrm{mM})$, a drug that inhibits viral RNA production (33). Total RNAs were extracted 16 hours after infection for the Mengo and Cox viruses and 24 hours after infection for MV. The purified RNA molecules were then used for the transfection of either HEK293 or ST-LGP2 cells together with a reporter plasmid expressing the luciferase gene $(l u c)$ under the control of the IFNB1 promoter sequence. Transfection of the HEK293 cells with total RNAs purified from $\mathrm{MV}$-infected cells induced a dose-dependent activation of the IFNB1 promoter, whereas transfection of the ST-LGP2 cells did not result in the same increase in IFNB1 promoter activity (Fig. 1E), similarly to what we observed in cells treated with 5'3P-RNA (Fig. 1B). Transfection of the ST-LGP2 cells with total RNAs extracted from Mengo- or Cox-infected cells induced statistically significantly greater IFNB1 promoter activity than that observed in transfected HEK293 cells (Fig. 1E). However, increasing amounts of RNAs purified from Mengo-infected cells attenuated the IFNB1 promoter activity in transfected ST-LGP2 cells. Furthermore, when Mengo or Cox infections were performed in the presence of ribavirin, no IFNB1 reporter activity was observed upon transfection of HEK293 cells with the resulting total RNAs (Fig. 1E). However, transfection of ST-LGP2 cells with the total RNA from Mengo-infected cells induced IFNB1 promoter activation, suggesting that $1 \mathrm{mM}$ ribavirin was not sufficient to inhibit Mengo replication in HeLa cells. Last, ultraviolet (UV) inactivation of Mengo and MV (which renders the viruses unable to replicate) before infection of HeLa cells led to the complete elimination of the immunostimulatory activities of the corresponding extracted total RNAs (Fig. 1F). Together, these results confirm that overexpressing ST-LGP2 increases cellular sensitivity to MDA5 ligands and reduces the response to RIG-I agonists.

\section{Identification of LGP2-specific protein partners}

Because LGP2 mutants lacking RNA binding activity are still capable of suppressing the RIG-I response (17), we searched for LGP2specific protein partners that could explain the LGP2-dependent control of RLR signaling. To identify LGP2-specific cellular protein partners, we applied a high-throughput proteomic approach that we previously developed and validated (24). ST-LGP2/protein cocomplexes were purified from ST-LGP2 cells by One-STrEP-tag affinity chromatography (12). A stable cell line expressing the OneSTrEP-Cherry protein (hereafter referred to as ST-CH) instead of tagged LGP2 was used as a negative control to enable subtraction of nonspecific binding. Data were obtained from three independent experiments and compared to the negative control $\mathrm{CH}$ /protein samples. LGP2- and CH-interacting proteins were resolved by SDS-polyacrylamide gel electrophoresis (SDS-PAGE) and visualized by silver staining, showing that more proteins copurified with LGP2 than with the negative control $\mathrm{CH}$ protein (fig. S1A). LGP2- and $\mathrm{CH}$-protein samples were further analyzed by liquid chromatographytandem mass spectrometry (LC-MS/MS) using our developed pipeline (Fig. 2A and fig. S1B). Spectra were analyzed using Mascot version 2.3 for the peptide and protein identification steps. A query was performed against a nonredundant database of 20,248 human protein sequences from Swiss-Prot to which corresponding decoy entries were automatically added.

LGP2-specific protein partners were determined by applying three filtering criteria. First, to be considered as a positive hit, the protein score had to be $>60$ in at least two of the replicates and not $<40$ for the third replicate. Second, if a protein was identified at least once in any of the $\mathrm{CH}$-protein triplicates with a score of $>20$, it was discarded. This filtering protocol limited false positives and enabled the generation of a list of highly specific LGP2 partners (table S2). This list includes well-known partners of LGP2, such as endoribonuclease Dicer (DICER1), interferon-induced, double-stranded RNA-activated protein kinase (PKR), NF- $\kappa \mathrm{B}-$ repressing factor 
A

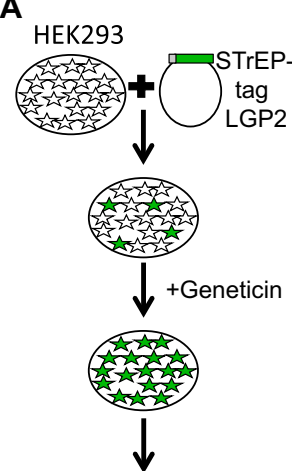

Single clone selection

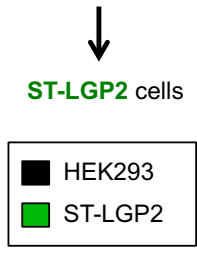

B

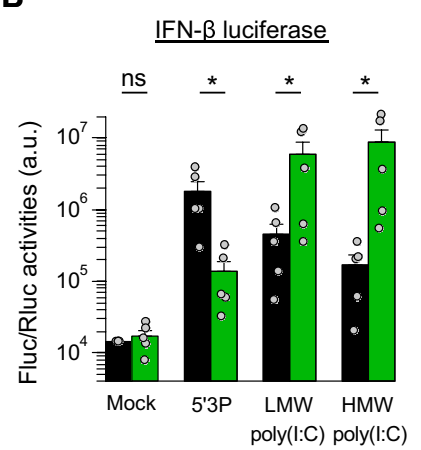

D

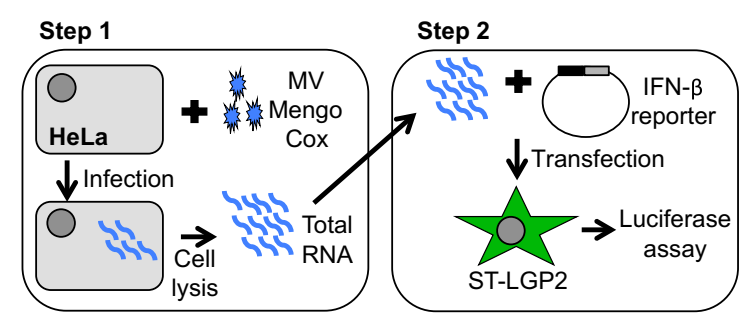

C
E

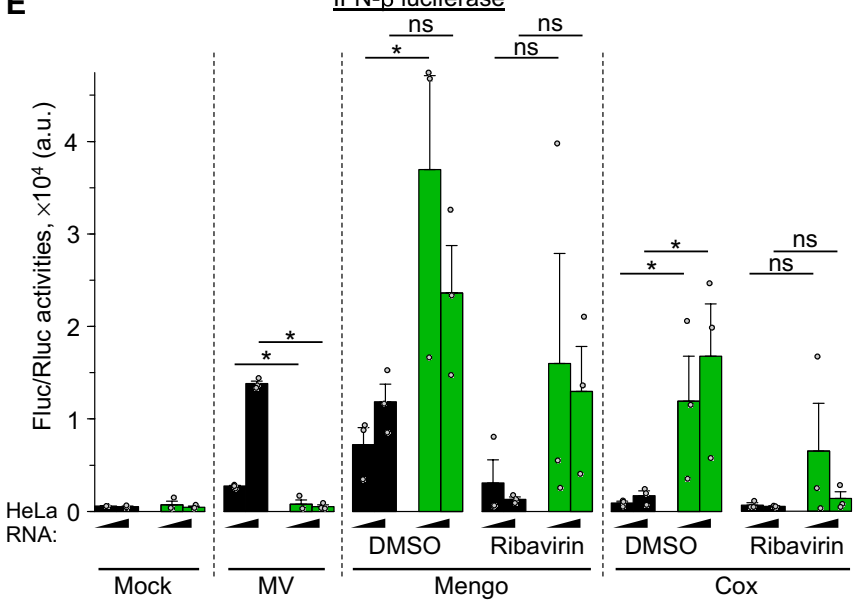

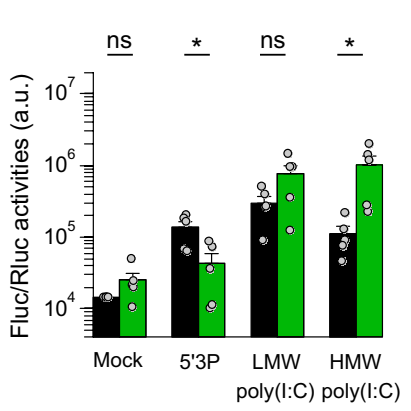

F $\quad \underline{\text { IFN- } \beta \text { luciferase }}$

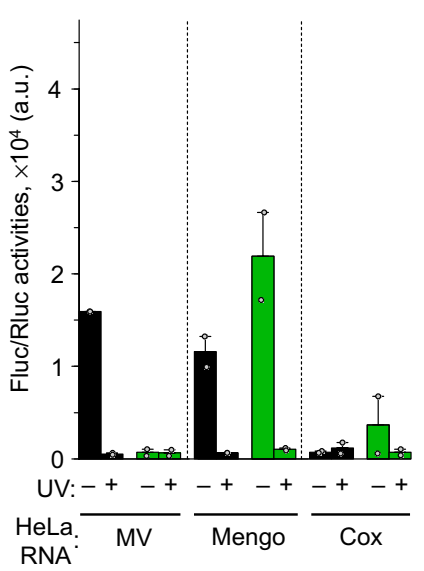

Fig. 1. ST-LGP2 cells exhibit inhibition of the type I IFN response to RIG-I-specific ligands but amplify the response to MDA5-specific ligands. (A) Workflow for generating the ST-LGP2 cell line. (B and C) Measurement of the IFN- $\beta$ (B) and NF-KB (C) promoter responses by luciferase assay in ST-LGP2 cells (green) and HEK293 cells (black) upon transfection with $100 \mathrm{ng}$ each of the indicated synthetic RLR ligands. HEK293 cells were included as a reference control. Data are means \pm SEM of five independent experiments. The asterisk indicates a significant difference. ns, no significant difference. a.u., arbitrary units. (D to F) Measurement of the responsiveness of ST-LGP2 cells to natural RLR ligands. (D) Purification protocol of RLR-specific natural ligands. HeLa cells were infected (at an MOl of 1 ) with MV, Mengo virus, or Cox virus or were left uninfected (mock). Infection with picornaviruses was performed in the presence of DMSO (as a control) or $1 \mathrm{mM}$ ribavirin (step 1). Total RNAs were then purified and used to transfect ST-LGP2 cells together with the IFN- $\beta$ reporter plasmid before being subjected to luciferase assays (step 2). (E) Comparative analysis of IFN- $\beta$ promoter responses in ST-LGP2 cells (green) and HEK293 cells (black) that were transfected with 20 or $100 \mathrm{ng}$ of total RNA isolated from cells infected with the indicated viruses. (F) Comparative analysis of IFN- $\beta$ promoter responses in the indicated cells after transfection with $100 \mathrm{ng}$ of total RNA isolated from cells infected with the indicated UV-inactivated viruses. Luciferase assays were preformed, and data were analyzed as described for (B). Data are means \pm SEM of three (E) and two (F) independent experiments. See table S1 for all details on statistical analysis.

(NKRF), double-stranded RNA-binding protein Staufen homolog (STAU1), DEAH box protein 30 (DHX30), and 5'-3' exoribonuclease 2 (XRN2) (table S2, gray entries) (18), confirming the sensitivity of our proteomics approach.

We then analyzed LGP2 partner proteins for Gene Ontology (GO) enrichment using the DAVID database $(34,35)$. GO term enrichments with $P$ values of $<0.05$ from three GO hierarchies (biological process, cellular compartment, and molecular function) were represented using the Cytoscape network analysis tool (36). Proteins from the GO terms "RNA splicing," "ncRNA metabolic process," "translation," "mitochondrion," and "posttranscriptional gene silencing" were found to be particularly enriched (Fig. 2B). Because of the direct involvement of LGP2 in type I IFN signaling, we also included the GO term "response to stimulus." We then generated a table with the corresponding $\mathrm{GO}$ term references, the number of proteins for each of the GO terms, and the respective $P$ values (Fig. 2B). Our data suggest that LGP2 has the capacity to interact directly and indirectly with numerous proteins that are the components of different cellular functional modules. One or several of these LGP2-specific protein partners could be involved in controlling RLR signaling.

\section{Validation of the interaction between LGP2 and components of the RNA-silencing machinery} Among the GO terms identified by our LC-MS/MS analysis, we focused on proteins of the RNA-silencing machinery because their involvement in the antiviral response in mammals is controversial (37) and because only five of these proteins were sufficient to contribute to a statistically significant $P$ value: DICER1, MOV10, SRRT, RBM4, and PACT (Fig. 2B, light blue).

We first confirmed the specific interaction of LGP2 with DICER1, PKR, and PACT by Western blotting analysis (Fig. 3A). These interactions appeared to be independent of viral infection because binding was observed both in mock- and MV-infected cells. As before, ST-CH protein was used to control for nonspecific protein binding. Transactivation-responsive RNA binding protein (TRBP) was previously found by a yeast two-hybrid assay to interact specifically with LGP2 and to be important for the cardiovirus-dependent IFN response (38). We were unable to confirm the specific binding of TRBP to LGP2 (Fig. 3A). We then focused on the LGP2-PACT interaction 
Fig. 2. Proteomic analysis of LGP2-specific host protein partners. (A) Workflow used to purify LGP2-associated cellular proteins. ST-LGP2 was copurified with interacting cellular partners using STrEP-Tactin beads. Protein complexes were released from the beads and analyzed by direct nano-LCMS/MS. Nonspecific binding was accounted for by using MS results for ST-CH protein (negative control) and our filtered protocol (fig. S1B). Three biological replicates were obtained and analyzed. (B) LGP2specific protein cocomplex. Proteins are represented according to their gene symbol and colors depict the corresponding GO term. For the corresponding gene name and protein score for each experimental replicate (see table S2). The $P$ value was obtained with the Fisher exact test, whereas the corrected $P$ value was determined with the Bonferroni test. ncRNA, noncoding RNA.
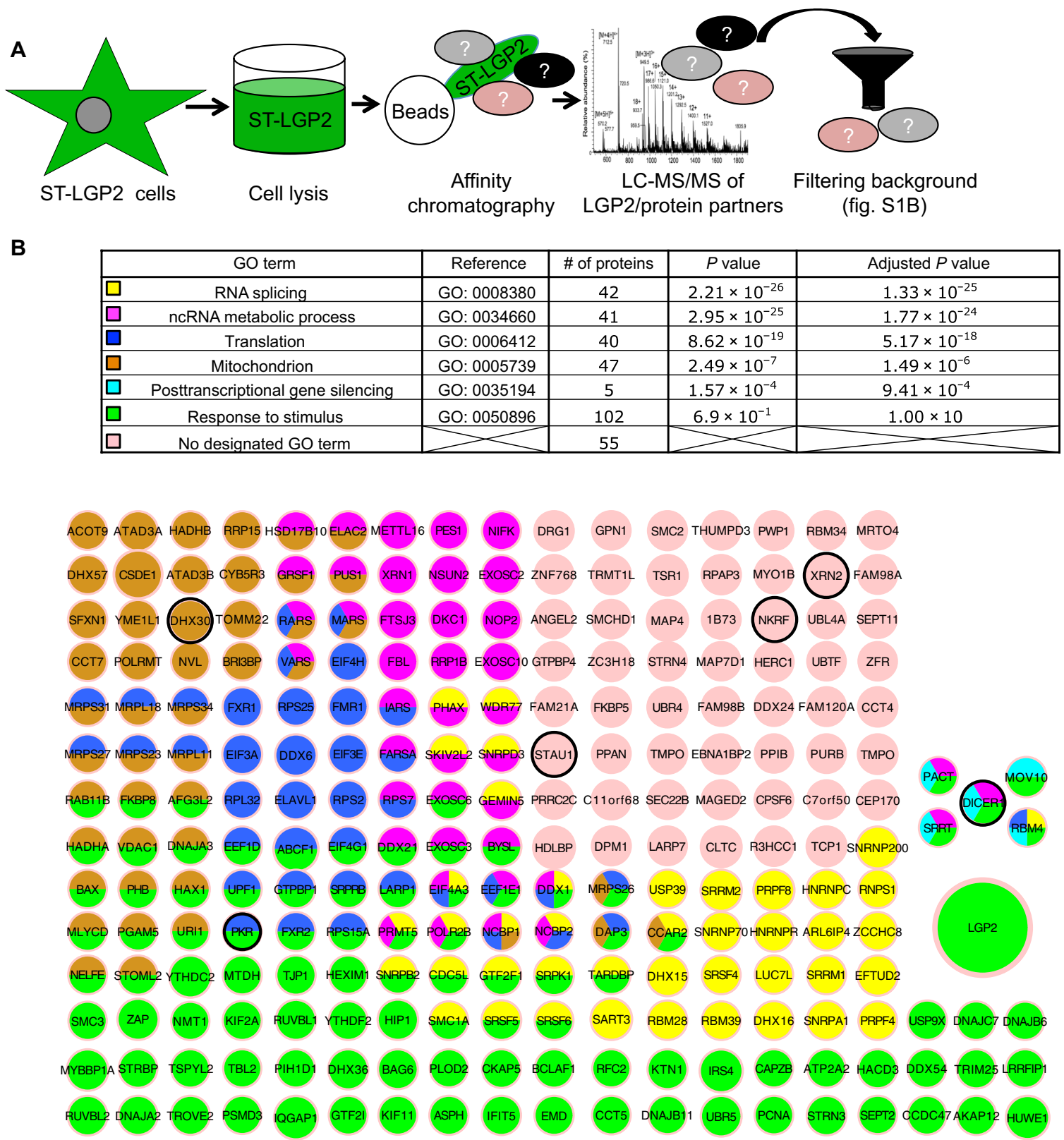

because PACT was previously shown to directly interact with the RIG-I CTD and to amplify RIG-I-dependent immunostimulatory activity (39). In addition, other studies have shown that different viruses, including Ebola virus, Middle East respiratory syndrome coronavirus (MERS-CoV), and severe acute respiratory syndrome coronavirus (SARS-CoV), target PACT to subvert the RIG-I-mediated response (40-42).

We first examined whether the interaction between LGP2 and PACT was RNA dependent. To this end, either the ribonuclease A (RNaseA), which specifically hydrolyzes RNA at C and $\mathrm{U}$ sites, or the dsRNA-specific RNaseIII were included in our One-STrEP-tag affinity chromatography protocol for the purification of LGP2protein cocomplexes. Both mock-infected and MV-infected conditions were examined. In both settings, the LGP2-PACT interaction was maintained in the presence of either RNaseA or RNaseIII (Fig. 3B).
In parallel, RNA integrity was controlled by RNA purification from each experimental condition (fig. S2A). We performed an additional control to validate the ability of RNaseIII to digest in vitro-transcribed dsRNA under the same conditions (fig. S2B). These results suggest that the LGP2-PACT interaction is mediated by protein-protein binding because it was unaffected by the presence of either RNaseA or RNaseIII.

\section{Validation of the direct protein-protein interaction between LGP2 and PACT}

To validate a direct protein-protein interaction between PACT and LGP2 and to examine PACT binding to other RLRs, we used a protein complementation assay (PCA) in which an interaction between prey and bait reconstitutes the luciferase activity (Fig. 4A) (43). RIG-I, MDA5, and LGP2 full-length proteins, as well as RIG-I and 


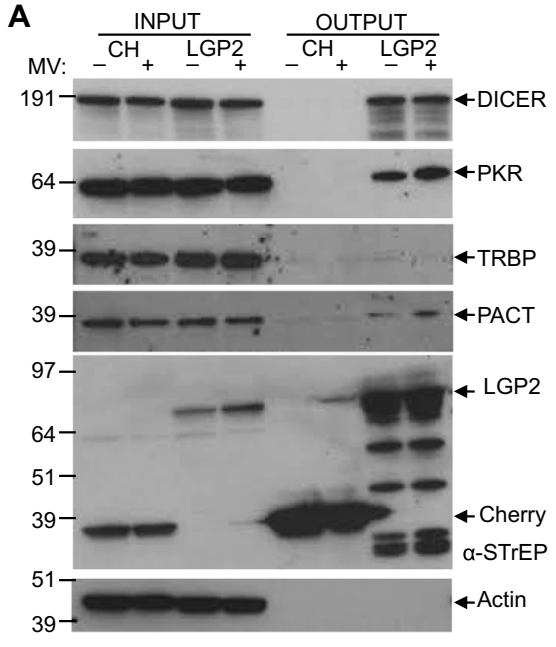

B

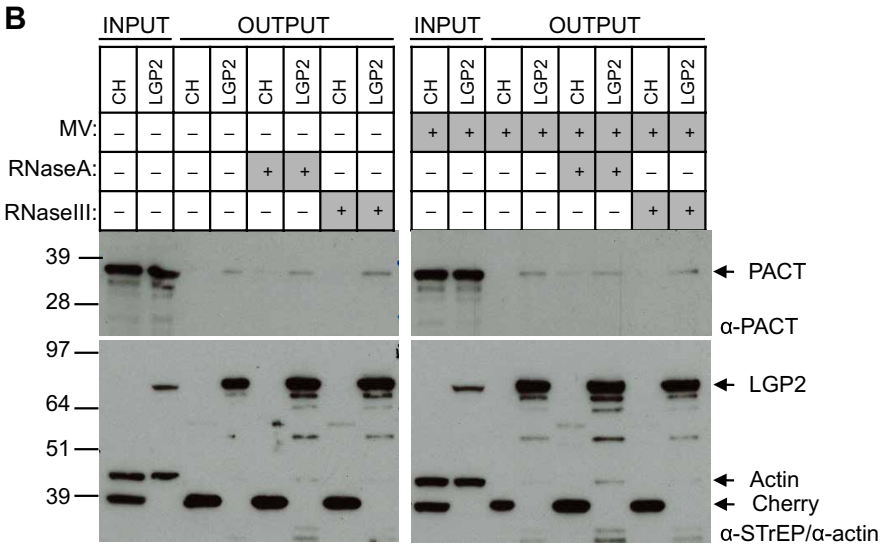

Fig. 3. Validation of the protein-protein interaction between LGP2 and PACT. (A) LGP2-specific binding to DICER1, PKR, and PACT. ST-LGP2 cells and ST-CH cells were infected with $\mathrm{MV}$ at an $\mathrm{MOI}$ of $1(+)$ or were left uninfected (-). Twenty-four hours after infection, total cell lysates (INPUT) were subjected to affinity purification with STrEP-Tactin beads (OUTPUT). Both sets of samples were then analyzed by Western blotting with specific antibodies against indicated proteins. Three biological replicates were analyzed. Blots from one representative experiment are shown. (B) The LGP2-specific interaction with PACT persists in the presence of RNase. ST-LGP2 cells and ST-CH cells were infected with MV at an MOI of 1 (+) or were left uninfected (-). Twenty-four hours later, total cell lysates (INPUT) were subjected to affinity purification with STrEP-Tactin beads in the absence or presence of either RNaseA or RNaselll (OUTPUT). Samples were then analyzed by Western blotting with antibodies against PACT, the STrEP tag, and actin. Two biological replicates were analyzed. Blots from one representative experiment are shown.

LGP2 CTDs, were tested in the PCA to assess their binding with each other and with full-length PACT (Fig. 4B). We validated the interaction between RIG-I CTD and PACT (Fig. 4C), which is consistent with a previous report (39). We found a higher luciferase score for LGP2-PACT than for RIG-I-PACT, and the regulatory CTD of LGP2 was sufficient to reconstitute the LGP2-PACT interaction (Fig. 4C). Our PCA and proteomic approaches failed to identify a direct interaction between RIG-I and LGP2 and between their corresponding CTDs. We also validated the previously reported interaction between MDA5 and LGP2 (44) and the binding of PACT to MDA5 (45) (Fig. 4C). In addition, the PCA confirmed the efficient homo-oligomerization of PACT (46), MDA5 $(47,48)$, and LGP2 (10).
Our results also highlight the property of LGP2 CTD to form quaternary structures independently from the helicase domain.

We further confirmed the LGP2-PACT interaction with an enzyme-linked immunosorbent assay (ELISA) with purified PACT and LGP2 proteins. More specifically, all three RLRs were compared for their ability to bind to PACT. Double dilutions of each affinity chromatography purified RLR were incubated with platebound recombinant PACT protein expressed in Escherichia coli. Affinity-purified $\mathrm{CH}$ protein was used as a negative control. To achieve a similar starting concentration for each RLR, the concentration of the affinity-purified proteins was controlled by Western blotting analysis before each experiment (Fig. 4D). We observed that all three RLRs interacted with PACT with similar efficiencies, whereas, as expected, the negative control $\mathrm{CH}$ protein failed to bind to PACT (Fig. 4D).

We then performed an additional PCA to test whether LGP2 affected the PACT-RIG-I and PACT-MDA5 interactions. The PACT-RIG-I and PACT-MDA5 pairs were evaluated in the presence of LGP2 protein. PCA scores demonstrated that the PACTRIG-I interaction was not affected by the addition of LGP2, whereas the addition of LGP2 to the PACT-MDA5 pair decreased the associated PCA scores (fig. S3, A and B). Together, these results validate that LGP2 interacts with PACT and that this interaction is mediated by the regulatory CTD of LGP2. The data also confirm the previously published interactions of RIG-I and MDA5 with PACT $(39,45)$.

\section{The LGP2-PACT interaction is involved in the regulation of the RIG-I signaling pathway and a single C615A mutation in LGP2 abolishes this interaction}

To assess the relevance of the LGP2-PACT interaction, we searched for point mutations in LGP2 that resulted in a lack of regulatory activity. Pippig et al. (19) previously observed that a single mutation (C615A) in the zinc-binding motif of LGP2 abolished the LGP2 regulatory activity over RIG-I and MDA5 (Fig. 5A). We thus analyzed by PCA the capacity of this mutant LGP2 to interact with PACT. In cell cotransfected with plasmids encoding PACT and with mutated LGP2 or its mutated CTD, the luciferase activity was statistically significantly reduced compared to that in cells expressing wild-type (WT) LGP2 (Fig. 5B). However, the mutated LGP2 CTD was still able to homo-oligomerize, indicating that it can still form quaternary structures and properly fold. To exclude the effect of the C615A single point mutation on the biochemical and, as a result, on the binding properties of the protein, we used PCA to assess the interactions between LGP2 and LGP2-C615A with five other LGP2 protein partners, either previously known or else identified here, such as MAVS, radical $S$-adenosyl methionine domain-containing protein 2 (RSAD2), 2'-5'-oligoadenylate synthase 2 (OAS2), RNA-binding protein 4 (RBM4), and serrate RNA effector molecule homolog (SRRT) (fig. S4A). Of these, only PACT protein showed lower binding scores with LGP2-C615A that with WT LGP2. By contrast, interactions between LGP2 and MAVS, RSAD2, OAS2, RBM4, or SRRT were not affected by the single point mutation in LGP2.

We also addressed the RNA binding activities of LGP2-C615A. We previously demonstrated that defective interfering (DI) genomes of MV are specific RNA ligands for LGP2 and that this RNA-protein interaction is not dependent on RIG-I (49). Using affinity purification approaches, we compared the ability of either LGP2 or LGP2-C615A to bind to DI genomes. Both LGP2 and LGP2-C615A cell lines were infected with a recombinant MV strain 


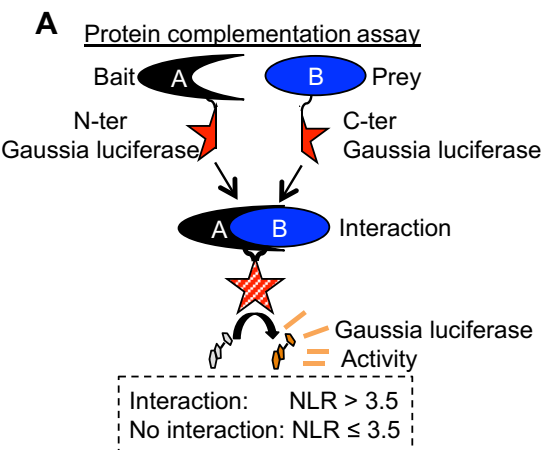

B

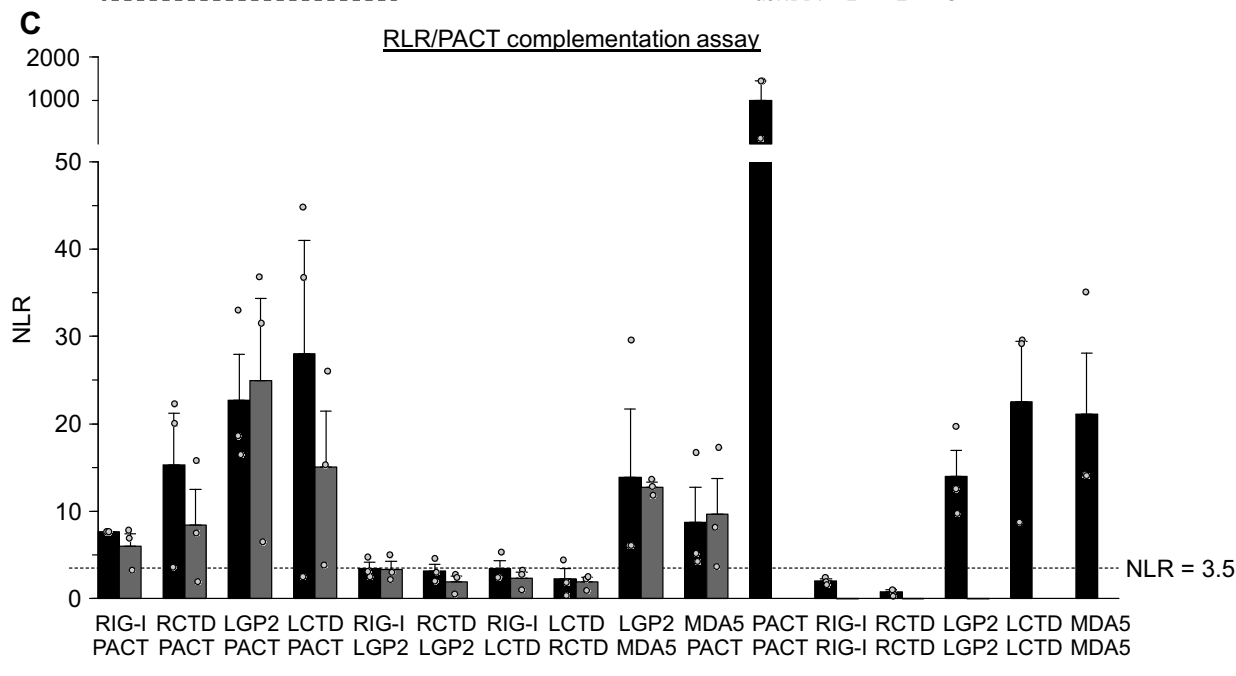

D
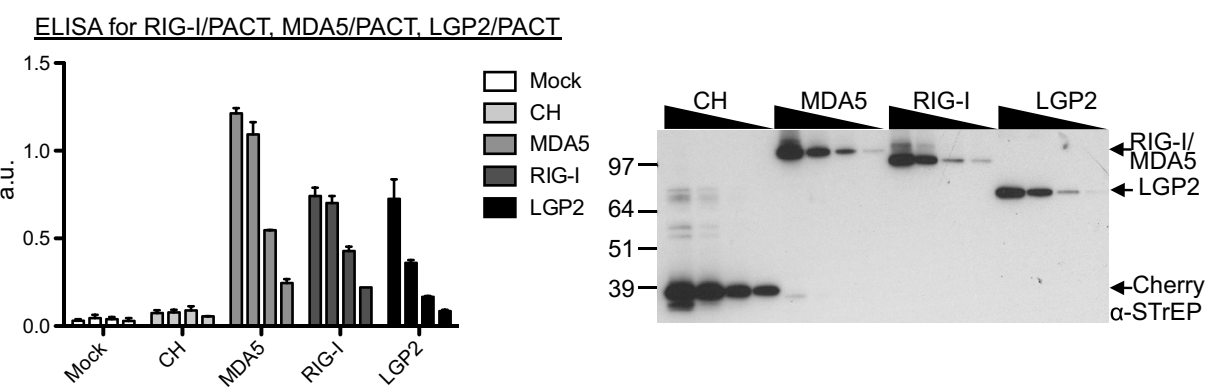

Fig. 4. Additional validation of the LGP2-PACT interaction. (A) Schematic representation of the PCA. Protein A (prey) is fused to the $\mathrm{N}$ terminus of the Gaussia luciferase (GL1). Protein B (bait) is fused to the $\mathrm{C}$ terminus of the Gaussia luciferase $(G L 2)$. If protein $A$ interacts with protein $B$, the luciferase activity is rescued and the normalized luciferase ratio (NLR) is >3.5. (B) Schematic representation of the organization of the RIG-I, RIG-I CTD (RCTD), LGP2, LGP2 CTD (LCTD), and PACT proteins that were used for the PCA. (C) PACT interacts with the CTD of RIG-I and LGP2. HEK293T cells were cotransfected with the plasmids GL1 and GL2 expressing the indicated proteins, and PCA was performed and luciferase measurements were made. Black columns indicate where protein $A$ was fused to GL1 and protein $B$ was fused to $G L 2$, whereas gray columns indicate where protein $A$ was fused to $G L 2$ and protein $B$ was fused to GL1. Data are means \pm SEM of three independent experiments. (D) Binding of PACT protein to RLRs. Left: ELISA plates were coated with PACT and incubated with similar concentrations of MDA5, RIG-I, and LGP2. Cherry (CH) was used as a negative control. Bound RLRs were detected with an antibody against the Strep tag. One representative experiment from a series of four is shown. Nonspecific binding of RLRs to the plates was subtracted. Data are means \pm SD of technical duplicates. Right: The indicated samples were analyzed by Western blotting with antibody against the STrEP tag to normalize the amounts of RLRs used for the ELISAs. dsRBD, dsRNA binding domain.

known to express a DI genome of 504 nucleotides (nt) in length. The ST-CH stable cell line was used as a negative control to exclude nonspecific binding to RNA. We observed that the LGP2-C615A mutant retained the ability of bind to the 504-nt-long DI genomes produced during MV replication (fig. S4B), albeit with less affinity than did WT LGP2. These data suggest that LGP2-C615A is still capable of binding to RNA. We then generated a stable cell line overexpressing ST-LGP2-C615A in a similar fashion as the ST-LGP2 cell line. The amounts of LGP2 transcripts and protein were similar in the two cell lines (Fig. 5, C and D). When copurifying LGP2-C615A with its cellular partners from ST-LGP2-C615A cells using our pull-down protocol, PACT no longer coimmunoprecipitated with the mutant LGP protein (Fig. 5D).

To better demonstrate the functional role of the LGP2-PACT interaction for the regulation of the RIG-I-mediated type I IFN response, ST-LGP2 and STLGP2-C615A cells were transfected with increasing amounts of 5'3P RNA or with total RNA from MV-infected HeLa cells together with the IFN- $\beta$ reporter plasmid. We found that the inhibitory effect of LGP2 overexpression on IFN- $\beta$ promoter activity was lost in the STLGP2-C615A cells stimulated either by $5^{\prime} 3 \mathrm{P}$ or RNAs purified from MVinfected HeLa cells (Fig. 5, E and F). In addition, type I IFN signaling was analyzed by evaluating the mRNA abundances of IFN- $\beta$ and IFIT1 (an ISG) in total RNA purified from MV-infected cells. These experiments showed that the STLGP2-C615A cells lacked an inhibitory effect on the induction of type I IFN signaling, whereas the ST-LGP2 cells failed to exhibit stimulation of the IFN- $\beta$ signaling cascade when they were infected (Fig. 5, G and H), findings that are consistent with the results from our earlier IFN- $\beta$ reporter assays (Fig. 5, E and F). Together, these results confirm that the regulatory CTD of LGP2 mediates the LGP2-PACT interaction and that a single mutation in this domain is sufficient to abolish this interaction. These data also suggest that the LGP2-PACT interaction may play a central role in regulating RIG-I signaling.

\section{The LGP2-PACT interaction is required for the ability of LGP2 to synergize with MDA5}

To better understand the effect of the LGP2-C615A mutation on MDA5 signaling, we first analyzed by PCA whether the LGP2MDA5 interaction was abrogated with the C615A mutation. We 
Fig. 5. The LGP2-PACT interaction is required for modulating $R L R$ signaling activity. (A) Structure of the human LGP2 CTD (Protein Data Bank: 2w4r). The domain is colored in yellow. The residues $\mathrm{C556}$, C559, and $\mathrm{C} 612$ from the zinc finger domain are colored in blue; C615 is colored in red; the loop between $\mathrm{C} 612$ and $\mathrm{C} 615$ is colored in cyan; and the zinc atom is in gray. (B) The LGP2-C615A mutant fails to interact with PACT. HEK293T cells were cotransfected with the plasmids GL1 and GL2 expressing the indicated proteins, and PCA was performed and luciferase measurements were made. Black columns indicate where protein A was fused to $G L 1$ and protein $B$ was fused to $G L 2$, whereas gray columns indicate where protein $A$ was fused to GL2 and protein B was fused to GL1. Data are means \pm SEM of two independent experiments. (C and D) Characterization of the ST-LGP2-C615A cell line. (C) Analysis of the amounts of $L G P 2$ mRNA relative to that of GAPDH mRNA in the indicated cells. Data are from three biological replicates. (D) Analysis of the binding of LGP2-C615A to PACT. Lysates of the indicated cells (INPUT) were subjected to affinity purification with STrEP-Tactin beads (OUTPUT). The samples were then analyzed by Western blotting with antibodies against STrEP tag, PACT, and $\beta$-actin. One representative experiment of three biological replicates is shown. ( $E$ and $\mathbf{F}$ ) Comparative analysis of IFN- $\beta$ promoter responses to RIG-I ligands. The indicated cells were transfected with 20, 100, and $200 \mathrm{ng}$ of 5'3P-RNA (E) or with RNA isolated from MVinfected HeLa cells (F) before being analyzed by luciferase assay. Data are means \pm SEM of three independent experiments. ( $\mathbf{G}$ and $\mathbf{H}$ ) Comparative analysis of the relative abundances of IFN- $\beta$ (G) and IFIT1 (H) mRNAs upon infection of the indicated cell lines with MV. Data are means \pm SEM of four independent experiments. See table S1 for all details on statistical analysis. Asterisks indicate statistical significance. ns, not significant.
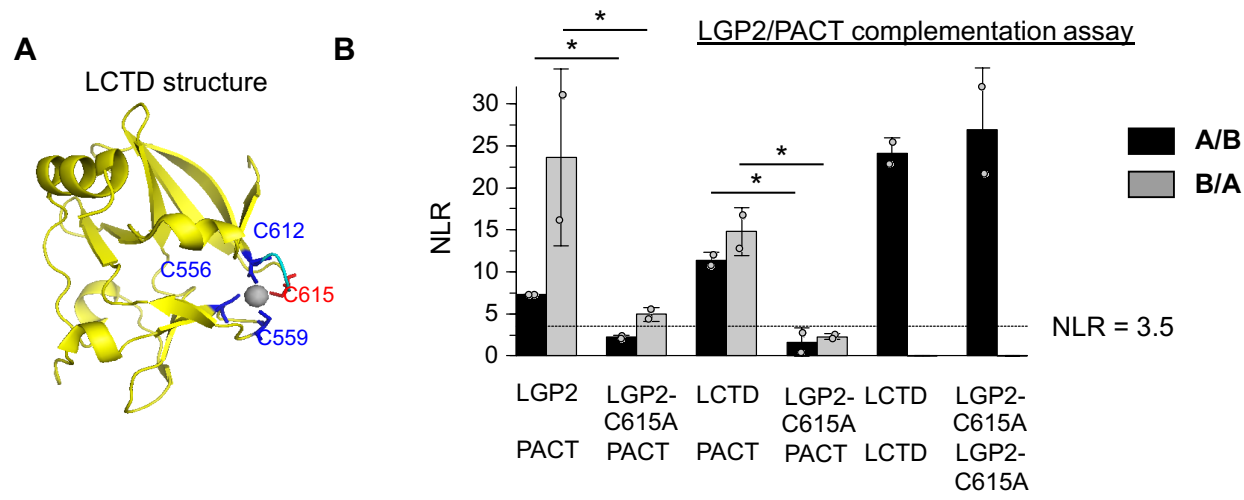

C

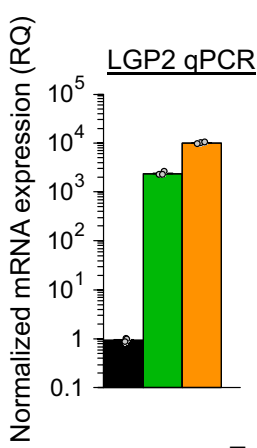

D

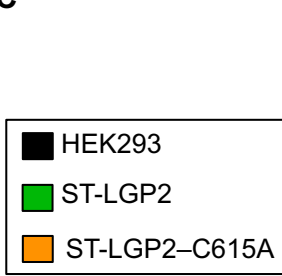

E

$\underline{5 \cdot 3 \mathrm{P}}$

$\mathbf{F}$
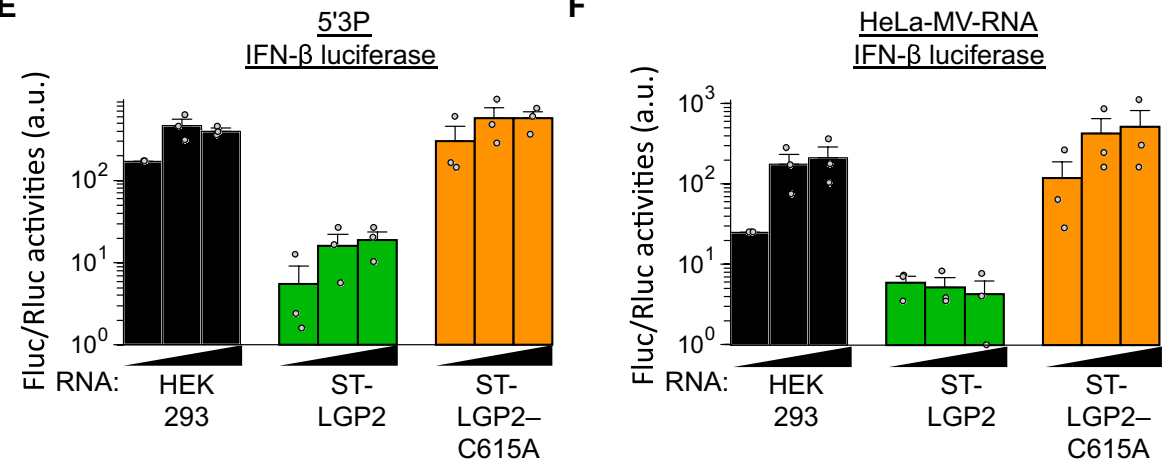

G

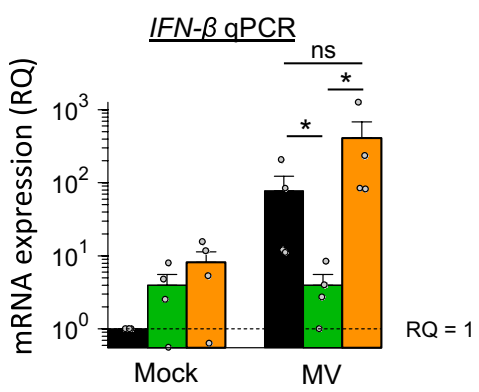

H

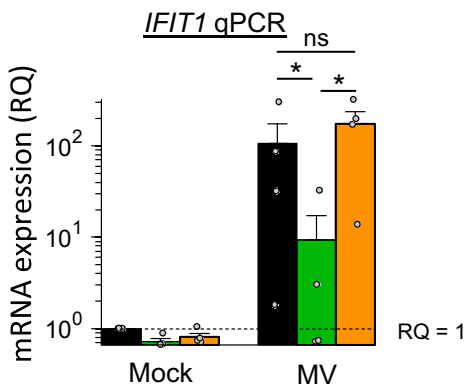

observed similar normalized luminescence ratio (NLR) scores with MDA5 in cells expressing either WT LGP2 or LGP2-C615A (Fig. 6A). Thus, that mutation does not appear to interfere with the MDA5LGP2 interaction. We then analyzed the role of the LGP2-PACT interaction in the synergy between LGP2 and MDA5 to stimulate type I IFN signaling. We transfected ST-LGP2 cells with increasing amounts of a PACT-expressing plasmid together with MDA5-specific synthetic or natural ligands (Fig. 6B). We observed an increased IFN- $\beta$ promoter activity that correlated with increasing amounts of PACT-expressing plasmid, suggesting a role for PACT in the ability of LGP2 to enhance MDA5 responses. Overexpression of PACT in standard HEK293 cells had little or no effect on the immunostimulatory activity of MDA5-specific ligands. Furthermore, transfection with HMW poly(I:C) did not amplify IFN- $\beta$ promoter activity in ST-LGP2-C615A cells compared to that in STLGP2 cells (Fig. 6C). 
A
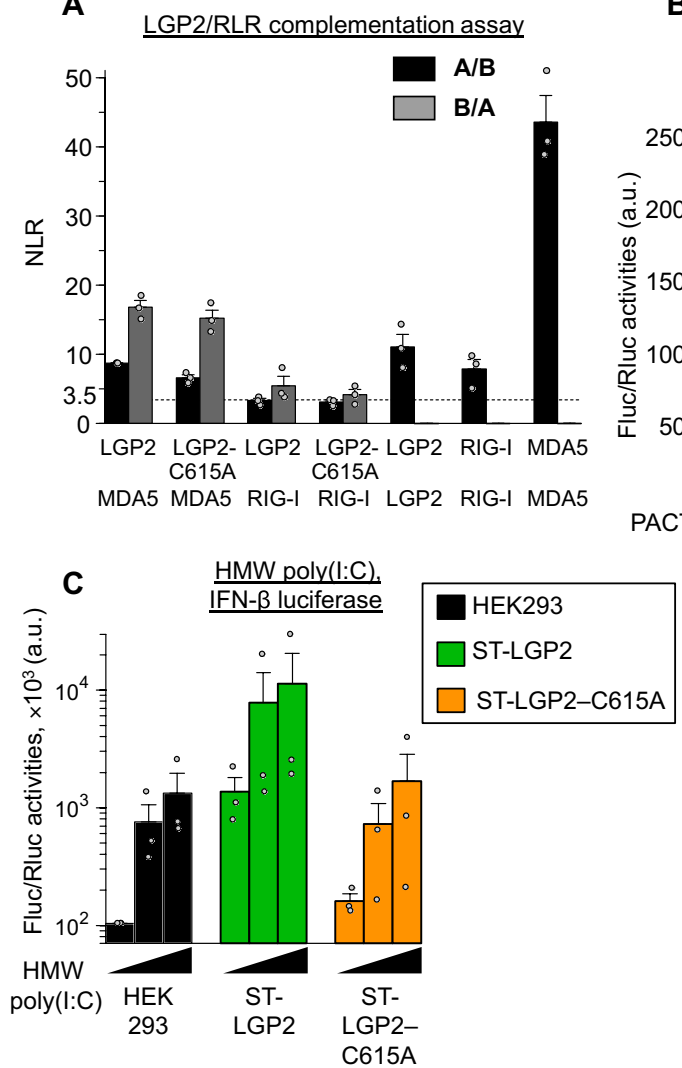

B

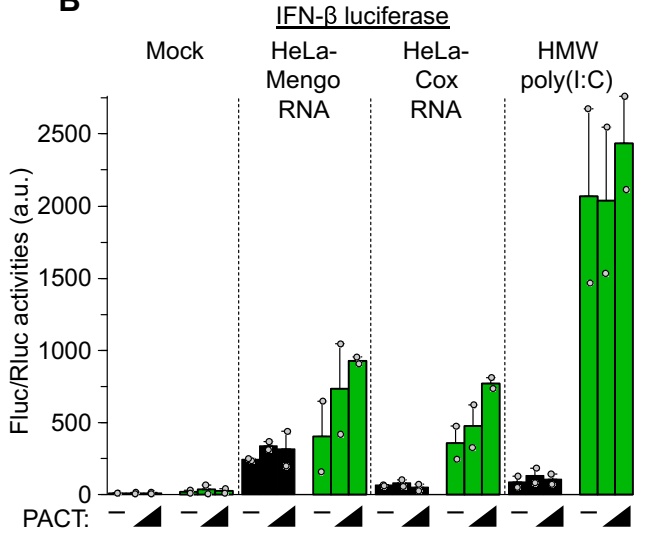

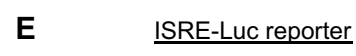

E

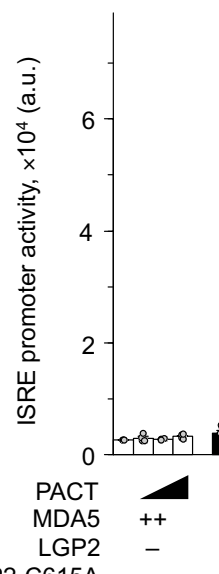

LGP2-C615A

Fig. 6. The LGP2-PACT interaction drives the synergy between LGP2 and MDA5. (A) Both WT LGP2 and the LGP2-C615A mutant interact with MDA5. HEK293T cells were cotransfected with the plasmids GL1 and GL2 expressing the indicated proteins, and PCA was performed and luciferase measurements were made. Black columns indicate where protein A was fused to $G L 1$ and protein $B$ was fused to $G L 2$, whereas gray columns indicate where protein $A$ was fused to $G L 2$ and protein $B$ was fused to GL1. Data are means \pm SEM of three independent experiments. Samples were analyzed in triplicate. (B) ST-LGP2 cells were transfected with 0,40 , or $100 \mathrm{ng}$ of $\mathrm{pCl}$-neo encoding PACT and $100 \mathrm{ng}$ of total RNA from Mengo- or Cox-infected HeLa cells or $100 \mathrm{ng}$ of HMW poly(l:C) before being analyzed by luciferase assay. Data are means $\pm \mathrm{SEM}$ of two independent experiments. (C) Comparative analysis of IFN- $\beta$ promoter responses to MDA5 ligands. The indicated cells were transfected with 20,100 , or 200 ng of HMW poly $(l: C)$ and then analyzed by luciferase assay. Data are means $\pm S E M$ of three independent experiments. (D) An ISRE reporter cell line was transfected with pCl-neo plasmids encoding LGP2 (20 ng), RIG-I (20 ng), or MDA5 $(20 \mathrm{ng})$, alone or in the indicated combinations, before promoter activities were measured. Data are means \pm SEM of three independent experiments. (E) An ISRE reporter cell line was cotransfected with pCl-neo plasmids encoding MDA5 ( $25 \mathrm{ng}$ ), either WT LGP2 or the LGP2-C615A mutant $(0,5,25,50$, or $100 \mathrm{ng})$, and PACT $(0,5,50$, or $100 \mathrm{ng})$ before promoter activities were measured. Data are means \pm SEM of four independent experiments. See table S1 for all details on statistical analysis. Asterisks indicate statistical significance. ns, not significant.

To further characterize the involvement of PACT in the synergy between LGP2 and MDA5, we measured type I IFN stimulatory activity upon transfection of STING-37 cells that stably express the luc gene under the control of a promoter sequence containing five IFNstimulated response elements (ISREs) with plasmids encoding RIG-I, MDA5, and LGP2 (Fig. 6D) (4). No stimulation with MDA5-specific ligands was required to activate ISRE promoter activity when the cells coexpressed MDA5 and LGP2, thus validating an experimental model for analyzing cooperativity between MDA5 and LGP2 for endogenous dsRNA (Fig. 6D) (10). Last, we observed that the MDA5 signaling activity triggered by the coexpression of MDA5 and LGP2 was additionally amplified in a PACT-dependent manner (Fig. 6E). However, the synergy between MDA5 and LGP2 was lost when the cells expressed the LGP2-C615A mutant, which removed any dependence on PACT for this response. These experiments highlight the importance of the direct protein-protein interaction between LGP2 and PACT for the enhancement of MDA5-mediated immune responses to self and nonself RNAs.

\section{DISCUSSION}

The RLR family of innate immune receptors is responsible for triggering the signaling cascade involving the IRF and NF- $\mathrm{BB}$ pathways upon viral infection. In contrast to RIG-I and MDA5, LGP2 is unable to bind to the downstream adaptor MAVS through CARD homotypic interactions. LGP2 acts as an inhibitor of RIG-I signaling cascade and an activator of MDA5 signaling $(10-12,14,15,17)$. To further understand the mechanism underlying the modulation of these two RLRs by LGP2, we used a cell line overexpressing LGP2 fused to a N-terminal STrEP-tag (Fig. 1A) (12). We observed that transfection of MDA5-specific ligands resulted in an increased activity in ST-LGP2 cells, whereas RIG-I-specific ligands lost their immunostimulatory activity (Fig. 1, $\mathrm{B}$ to E). Although LMW poly(I:C) specifically triggers RIG-I, but not MDA5 (26), when it was used to transfect STLGP2 cells, the result was an increased immunostimulatory activity. We speculate that upon transfection of LMW 
poly(I:C) in our cellular model, LGP2 enhanced signaling through MDA 5 by increasing its affinity for shorter dsRNA structures (10).

We then identified a set of LGP2 protein partners by affinity chromatography purification of LGP2 in association with specific macromolecular complexes from ST-LGP2 cells, which was followed by LC-MS/MS analysis (Fig. 2A). Upon proteomic data analysis, we focused our efforts on members of the RNA silencing machinery that coimmunoprecipitated with ST-LGP2. Our choice was motivated by several arguments: (i) that the RLR helicase domain is a direct paralog of the DICER helicase domain (50), (ii) that RLR orthologs in nematodes sense viral dsRNA to initiate the antiviral small interfering RNA (siRNA) response $(51,52)$, and (iii) that the involvement of the RNA-silencing machinery in the mammalian RLR response remains unclear (37).

PACT is the direct paralog of TRBP. Both proteins contain two dsRNA binding domains and serve as cofactors for DICER in the processing and biogenesis of microRNAs (53). The LGP2-TRBP interaction enhances viral RNA sensing by LGP2-MDA5 upon infection with the picornavirus cardiovirus (38). Note that in our study, TRBP-LGP2 binding had no negative effect on RIG-I signaling. Only trace amounts of TRBP were detected by our MS approach, and the protein failed to pass our MS data filtering criteria. Moreover, Western blotting analysis failed to validate an LGP2specific interaction with TRBP (Fig. 3A). It would be interesting in future studies to compare the relative strengths of the LGP2-PACT and LGP2-TRBP interactions and to understand whether LGP2 can selectively bind to PACT, TRBP, or both to modulate the RLR response.

Increasing evidence links PACT to the host antiviral response. First, overexpression of PACT leads to PKR activation (54). Second, PACT interacts with the CTD of RIG-I and activates its immunostimulatory activity (39). Third, PACT facilitates the RNA-induced formation of MDA5 oligomers (45). Last, different viral proteins have been described to antagonize PACT to subvert the RLR signaling cascade (40-42). Therefore, PACT appears as an interesting candidate to be involved in the regulatory effect of LGP2 on the RLR response. Two independent studies have described the LGP2PACT interaction $(55,56)$. To validate the protein-binding nature of the LGP2-PACT interaction, we performed affinity purification of LGP2-specific protein complexes in the presence of the ribonucleases RNaseA and RNaseIII (Fig. 3B). The efficiency of RNA cleavage was controlled in a parallel experiment by RNA extraction from the corresponding samples (fig. S2). We observed that the LGP2-PACT interaction was resistant to RNAses. These data are consistent with the findings reported by van der Veen et al. (55).

We used PCA as a second approach to validate the LGP2-PACT protein-protein interaction (43). This method enabled us to determine that PACT interacts with LGP2 through the LGP2 CTD (Fig. 4C). We also confirmed that PACT interacts with the RIG-I CTD (39). We observed high PCA scores for the LGP2-PACT and LGP2 CTD-PACT pairs, suggesting that there is an efficient interaction between LGP2 and PACT. The binding of PACT to LGP2 was further validated by ELISA (Fig. 4D). In the same assay, we observed that all three RLRs bound to PACT with similar efficiencies. Additional PCA experiments showed that LGP2 was unable to perturb the PACT-RIG-I interaction (fig. S3A), whereas the MDA5-PACT interaction was less stable in the presence of LGP2 (fig. S3B). Furthermore, we found that a single mutation (C615A) disrupted LGP2-specific binding to PACT without modifying its ability to bind to MDA5 (Fig. 6A) and only slightly decreased the scores of binding with five other cellular protein partners of LGP2: MAVS, RASD2, OAS2, RBM4, and SRRT (fig. S4A). We also observed that the LGP2-C615A mutant maintained (albeit a decreased) specific RNA-protein interaction with MV DI genomes (fig. S4B). The LGP2-C615A mutant was studied through a panel of approaches to understand the extent of the regulatory activity that the LGP2-PACT interaction exerts over the type I IFN signaling cascade. We next showed that disrupting the LGP2-PACT interaction disrupted the regulatory effect that LGP2 has over RIG-I and MDA5 signaling (Figs. 5 and 6).

We failed to detect an interaction between LGP2 and RIG-I by LC-MS/MS (Fig. 2B) or PCA (Fig. 4C), in contrast with previous reports $(9,15)$ but in accordance with others $(18,19)$. Thus, the previously hypothesized mechanism of RIG-I regulation by LGP2 through direct protein-protein interaction is questioned. We propose a model in which the LGP2-PACT complex regulates RIG-I through a PACT-RIG-I interaction. More studies should be performed to uncover the detailed molecular mechanism by which RIG-I is regulated by the LGP2-PACT complex.

Different genetic studies have identified a connection between MDA5 and different autoimmune disorders (57). There is a direct link between MDA5 filament formation on short dsRNA and the MDA5 genotypes linked to these diseases (58). Previous studies showed that cotransfection of cells with plasmid encoding MDA5 and low amounts of LGP2-encoding plasmid can trigger MDA5 signaling activity by increasing its affinity for short dsRNA $(10,27)$. We observed the same phenotype when we cotransfected the ISRE reporter cell line STING-37 with plasmids encoding MDA5 and LGP2 (Fig. 6D). Note that the presence of increasing amounts of PACT exacerbated this phenomenon only when WT LGP2 was overexpressed and not when we overexpressed the LGP2-C615A mutant, which is unable to interact with PACT (Fig. 6E). Hence, these data suggest that the ability of LGP2 to synergize with the MDA5-specific immune response requires PACT. Our work also suggests the possible involvement of PACT in the sensing of selfRNAs through MDA5.

Whether mammals are capable of eliciting a proper siRNAmediated antiviral response is a matter of controversy (59). In the nematode Caenorhabditis elegans, RLR orthologs are directly involved in the antiviral siRNA response by recognizing viral dsRNA $(51,52)$. A previous study described antiviral siRNA in mammals when MAVS signaling is inactive (60). Furthermore, another study suggested that the inefficiency of the RNA interference (RNAi) machinery in antiviral defense in mammalian somatic cells could be, in part, attributed to the inhibition of DICER by LGP2. The exact role of the LGP2-PACT interaction in inhibiting the RNAi machinery remains to be addressed. Rabies virus and influenza $A$ virus infections of transgenic mice overexpressing human LGP2 leads to a reduced inflammatory response while keeping virus replication lower than that in control mice $(22,23)$. All of these data suggest that LGP2 has an additional role in the antiviral response in mammals independently of IFN signaling. An RLR effector-like function independent of MAVS signaling has also been previously described (61). Given that the RLR helicase domain is a direct paralog of the DICER helicase domain (50) and that there is an interaction between LGP2 and the RNAi machinery, it would be interesting to address whether the effector-like function of RLRs could be orchestrated by an antiviral siRNA response. In conclusion, our study 
suggests that the LGP2-PACT interaction is fundamental for the regulation of RLR signaling and provides a previously uncharacterized connection between the cellular RNA-silencing machinery and the innate immune response. Our findings reveal the involvement of PACT in the recognition of self-RNAs and thus contribute to the increasing knowledge on the mechanisms leading to autoimmune disorders.

\section{MATERIALS AND METHODS Cells, plasmids, and recombinant viruses}

HEK293 [American Type Culture Collection (ATCC), CRL-1573)], HeLa (human cervix adenocarcinoma epithelial; ATCC, CCL-2), and Vero (fibroblast-like kidney cell from African green monkey; ATCC, CCL-81) cells were maintained in Dulbecco's modified Eagle medium (DMEM; \#61965-026, Gibco) supplemented with $10 \%$ heat-inactivated fetal calf serum (FCS) ((\#A15-101, GE Healthcare $)$ and penicillin $(100 \mathrm{U} / \mathrm{ml} /)$ and streptomycin $(100 \mu \mathrm{g} / \mathrm{ml})$ (\#15140122, Life Technologies). The absence of mycoplasma was regularly checked (\#30-1012K, ATCC) in all cell lines. To establish the ST-LGP2-C615A clonal stable cell line, we used a modified pEXPR-IBA105 plasmid carrying a Gateway (GW) cassette (pEXPRIBA105GW) as previously described (Fig. 1A) (12). The STING-37 cell line corresponded to HEK293 cells stably transfected with an ISRE-luc reporter gene (4). The ST-LGP2 and ST-CH cell lines have been previously described (12). The STING-37, ST-LGP2, ST-CH, and ST-LGP2-C615A cell lines were maintained in DMEM GlutaMAX, supplemented with $10 \%$ heat-inactivated FCS, penicillin (100 U/ml), streptomycin $(100 \mu \mathrm{g} / \mathrm{ml})$, and G418 (400 $\mu \mathrm{g} / \mathrm{ml}$; \#8168, Sigma). The sequences encoding LGP2, LCTD, RIG-I, RCTD, MDA5, and PACT were amplified by standard polymerase chain reaction (PCR) from a splenic complementary DNA library (Invitrogen) using specific primers with AttB1 and AttB2 sequences included (table S3). The corresponding DNA fragments were cloned by in vitro recombination into the pDONR207 entry vector (BP reaction, Gateway, Invitrogen). The pDON207 and pDON223 entry vectors encompassing the sequences encoding MAVS, RSAD2, OAS2, RBM4, SRRT, and MX1 originated from the Center for Cancer Systems Biology (CCSB) Human ORFeome Collection Dana-Farber Cancer Institute (DFCI). The attenuated MV Schwarz vaccine strain (MV) has been previously described (62). Recombinant MV-CHIKV (Chikungunya virus), expressing the CHIKV structural proteins $(\mathrm{E} 1, \mathrm{E} 2, \mathrm{E} 3, \mathrm{C}$, and $6 \mathrm{~K})$ in additional transcription unit (ATU2) and known to produce a 504-nt DI genome, was used to test LGP2- and LGP2-C615A-specific RNA ligands (49, 63). Mengo [WT Mengo virus, C50UC10 as previously described (64)] and Cox virus B3 (Nancy strain) were provided by N. Escriou (Unité de Génomique Virale et Vaccination, Pasteur Institute, Paris) and G. Moratorio (Institut Pasteur Montevideo, Uruguay), respectively. Virus stocks were produced on Vero cells and titrated by TCID 50 (median tissue culture infectious dose).

\section{Directional mutagenesis}

The LGP2-C615A and LCTD-C615A mutants were generated by directional mutagenesis using the plasmids pDONR207-LGP2 or pDONR207-LCTD. The forward primer (5' - TGTCATCAGCTGCAGGAACGCGGGGGAGGTCTGGGG-3') and reverse primer (5'-CCCCAGACCTCCCCCGCGTTCCTGCAGCTGATGACA-3') were used in accordance with the QuikChange Lightning Multi Site-
Directed Mutagenesis Kit protocol (\#210518-5 StrataGene). The LGP2C615A mutant was recombined from pDONR207 to One-STrEPtag pEXPR-IBA105GW by in vitro recombination (LR reaction).

\section{Synthetic RLR ligands}

Short, 5'3P-bearing RNA molecules were obtained from the pCI-neo plasmid linearized by Xba I before transcription. T7 transcription reactions were performed with a T7 RiboMAX Express Large-Scale RNA Production System (\#P1320, Promega). Poly(I:C) ligands are LMW (\#tlrl-picw, Invivogen) and HMW (\#tlrl-pic, Invivogen).

\section{Viral RLR ligands}

HeLa cells $\left(5 \times 10^{7}\right)$ were infected at an MOI of 1 for 16 hours with Mengo or CoxB3 viruses and for 24 hours with MV. Cells were washed twice with cold phosphate-buffered saline (PBS) and lysed in $2 \mathrm{ml}$ of lysis buffer [20 mM Mops-KOH (pH 7.4), $120 \mathrm{mM} \mathrm{KCl,}$ $0.5 \%$ Igepal, $2 \mathrm{mM} \beta$-mercaptoethanol]. RNA purification was performed using TRI Reagent LS (\#T3934, Sigma). RNA was dissolved in $80 \mu \mathrm{l}$ of deoxyribonuclease-free and RNase-free ultrapure water. Extracted RNAs were analyzed using NanoVue (GE Healthcare). For picornavirus infection, cells were pretreated with $1 \mathrm{mM}$ ribavirin (\#R9644, Sigma).

\section{IFN- $\boldsymbol{\beta}$ and NF- $\boldsymbol{\kappa} B$ reporter assays}

To determine the responsiveness of ST-LGP 2 cells to synthetic ligands, the expression of IFN- $\beta$ and NF- $\kappa \mathrm{B}$ was determined by transient transfection of the reporter plasmids pIFN $\beta$-Fluc and pNFкB-Fluc containing the Fluc gene under the control of the IFN- $\beta$ promoter [IFN-b-pGL3 (65)] or the NF- $\kappa$ B promoter (StrataGene). For RNA transfection analysis, cells were plated in 24 -well plates $\left(2 \times 10^{5}\right.$ cells per well). After 24 hours, the cells were transfected with pIFN $\beta$-Fluc or pNFkB-Fluc (250 ng per well), pTK-Rluc plasmid (25 ng per well), which contains a thymidine kinase promoter just upstream of the Rluc gene (Promega), and synthetic/natural RLR RNA ligands using jetPRIME reagent (\#114-07, Polyplus). After 24 hours, the cells were lysed, and the Fluc and Rluc activities were measured in cell lysates using the Dual-luciferase Reporter Assay System (\#2920, Promega) according to the manufacturer's instructions. Reporter activity was calculated as a triplicate of the ratio of Fluc activity to the reference Rluc activity.

\section{Antibodies and Western blotting analysis}

Protein extracts were resolved by SDS-PAGE on 4 to $12 \%$ Criterion gels ((\#345-0123, Bio-Rad) with Mops running buffer, and the samples were then transferred to cellulose membranes (GE Healthcare) with the Criterion Blotter system (Bio-Rad). The following antibodies were used: anti-STrEP-tag (\#34850, Qiagen), anti-LGP2 (\#HPA019570, Sigma), anti-PACT (\#sc377103, Santa Cruz Biotechnology), antiDICER1 (\#ab14601, Abcam), anti-TRBP (\#ab42018, Abcam), and monoclonal anti- $\beta$-actin antibody (A5441, Sigma). Horseradish peroxidase (HRP)-coupled anti-mouse (\#NA9310V, GE Healthcare) or anti-rabbit (\#RPN4301, GE Healthcare) antibodies were used as secondary antibodies. Peroxidase activity was visualized with an ECL Plus Western Blotting Detection System (\#RPN2132, GE Healthcare).

\section{Affinity chromatography of ST-LGP2 and subsequent protein purification}

ST-CH, ST-LGP2, and ST-LGP2-C615A cells $\left(5 \times 10^{7}\right)$ were plated and harvested after 24 hours. The cells were washed twice with cold PBS 
and lysed in $6 \mathrm{ml}$ of lysis buffer [20 mM Mops-KOH (pH 7.4), $120 \mathrm{mM}$ $\mathrm{KCl}, 0.5 \%$ Igepal, and $2 \mathrm{mM} \beta$-mercaptoethanol] supplemented with RNasin (200 U/ml; N2515, Promega) and cOmplete Protease Inhibitor Cocktail (\#11873580001, Roche). Cell lysates were incubated on ice for $20 \mathrm{~min}$ with gentle mixing every $5 \mathrm{~min}$ and then clarified by centrifugation at $16,000 \mathrm{~g}$ for $15 \mathrm{~min}$ at $4^{\circ} \mathrm{C}$. Cell lysates were incubated for 2 hours on a spinning wheel at $4^{\circ} \mathrm{C}$ with $200 \mu \mathrm{l}$ of StrepTactin Sepharose High Performance beads (\#28-9355-99, GE Healthcare). For the RNAse treatment assay, RNaseA (\#EN0531, Thermo Fisher Scientific) and RNaseIII (\#M0245 L, NEB) were used at final concentrations of $0.1 \mathrm{mg} / \mathrm{ml}$ and $5 \mathrm{U} / \mathrm{ml}$, respectively. Beads were collected by centrifugation $\left(1600 \mathrm{~g}\right.$ for $5 \mathrm{~min}$ at $4^{\circ} \mathrm{C}$ ) and washed twice for $5 \mathrm{~min}$ on a spinning wheel with $5 \mathrm{ml}$ of washing buffer [20 mM Mops-KOH (pH 7.4), $120 \mathrm{mM} \mathrm{KCl}$, and $2 \mathrm{mM}$ $\beta$-mercaptoethanol] supplemented with cOmplete Protease Inhibitor Cocktail. Precipitates were eluted using biotin elution buffer (\#2-1019-025, IBA). For the MS analysis, protein complexes were precipitated in $12 \%$ of trichloroacetic acid (TCA) (\#T0699, Sigma) after 16 hours at $4^{\circ} \mathrm{C}$. The dsRNA control for RNaseIII digestion encompassing $425 \mathrm{nt}$ of MV genome sequence (L2) was obtained as previously described (66).

\section{LC-MS/MS analysis}

Precipitated proteins $(1 \mu \mathrm{g})$ from ST-LGP2/protein and ST-CH/ protein complexes were used in each nano-LC-MS/MS experiment. Proteins were digested overnight at $37^{\circ} \mathrm{C}$ with $20 \mu \mathrm{l}$ of a trypsin solution prepared as follows: high-performance LC (HPLC) water, trypsin-sequencing grade $(12.5 \mu \mathrm{g} / \mathrm{ml}$; \#PRV5111, Promega), $10 \%$ HPLC grade acetonitrile (ACN), and $25 \mathrm{mM}$ ammonium carbonate (\#09830, Sigma Aldrich). The resulting peptide extracts were speed-vac-dried and dissolved in $12 \mu \mathrm{l}$ of HPLC grade water and $0.1 \%$ formic acid. Samples $(5 \mu \mathrm{l})$ were then used for nano-LCMS/MS analysis using a nanochromatography system (Easy nLC, Proxeon) connected online to a LTQ Velos Orbitrap (Thermo Fisher Scientific) mass spectrometer. A 2 -cm-long and $5-\mu \mathrm{m}$ particle size C18 Easy column (Proxeon) was used for peptide trapping and desalting. A $10-\mathrm{cm}-$ long and $3-\mu \mathrm{m}$ particle size C18 Easy column (Proxeon) was used for peptide separation. The peptide elution gradient was from $100 \%$ buffer A (HPLC grade water and $0.1 \%$ formic acid) to $35 \%$ buffer B (HPLC grade ACN and $0.1 \%$ formic acid) in $60 \mathrm{~min}$ using a constant flow of $300 \mathrm{nl} / \mathrm{min}$. MS spectra were acquired on the Orbitrap analyzer at resolution $R=30,000$. After each MS spectrum, an automatic selection of the 20 most intense precursor ions was activated with a 15-s dynamic exclusion delay to acquire MS/MS spectra on the LTQ Velos analyzer using CID fragmentation mode at $35 \%$ relative resonant activation energy for $40 \mathrm{msec}$. Raw data were preprocessed using ProteomeDiscoverer version 1.4 (Thermo Fisher Scientific). Preprocessing consisted of MS/MS spectrum averaging of spectra from equal precursor molecular weight, with a 5 parts per million (ppm) mass tolerance and a 90-s time window. No threshold was applied either to MS ions intensities or to MS/MS fragment ion intensities. All spectra were analyzed using Mascot version 2.3 (Matrix Science). Queries were performed against a nonredundant database of 20,352 human protein sequences from Swiss-Prot (release 2013-02). Mascot was run in MS/MS Ion search mode with the following parameter settings: no fixed modification, variable modification [oxidation (Met), phosphorylation (Ser, Thr, and Tyr), acetylation (Lys and N-term), deamidation (Asn and Gln)], precursor mass tolerance of $7 \mathrm{ppm}$, fragment ions mass tolerance of $0.5 \mathrm{Da}$, two missed cleavages, and trypsin as the digestion enzyme. False discovery rates were calculated for each peptide by the percolator node for validation of peptide identification. To reduce the number of nonspecific hits, if the protein hit presented a score of $>20$ in any of the three ST-CH replicates, the protein was immediately excluded from the list. A second filter was added whereby the protein had to have a score of $>60$ for two of the three replicates and could have a score of $>40$ for the third replicate (fig. S1A).

\section{LGP2 interaction network visualization}

For GO term enrichment analysis of biological process, cellular compartment, and molecular function, the list was analyzed in DAVID $(34,35)$. GO terms with $P$ values of 0.01 or less were selected. Furthermore, the LGP2 interaction network was represented on Cytoscape (36).

\section{Protein complementation assay}

Open reading frame (ORF) sequences corresponding to LGP2, LCTD, RIG-I, RCTD, and PACT were recombined from the corresponding pDONR207 plasmids into pGL1 and pGL2 vectors so that they could be expressed in fusions with fragments 1 to 93 (GL1) and 94 to 169 (GL2) of Gaussia princeps luciferase as previously described (43). HEK293T cells were seeded in 24-well plates at a concentration of $2 \times 10^{5}$ cells per well. After 24 hours, cells were transfected with $100 \mathrm{ng}$ of each of the Gluc1 and Gluc2 plasmid constructs. At 24 hours after transfection, the cells were harvested with $100 \mu \mathrm{l}$ of Renilla lysis buffer (\#E2820, Promega) for $30 \mathrm{~min}$. Gaussia princeps luciferase enzymatic activity was measured using a Berthold Centro XS LB960 luminometer by injecting $50 \mu \mathrm{l}$ of Renilla luciferase assay reagent (\#E2820, Promega) into $10 \mu \mathrm{l}$ of clarified cell lysates and counting the luminescence for $10 \mathrm{~s}$. For PCA analysis in the presence of LGP2, $200 \mathrm{ng}$ corresponded to the 1:1:2 mass concentration ratio (RIG-I or MDA5:PACT:LGP2) that was used for each transfection. The pCI-neo empty vector was used as a control. Results were represented as the fold-change normalized over the sum of the controls, specified herein as the NLR. For a given protein pair A-B, the luminescence activity of cells transfected with the GL1-A and GL2-B vectors (AB) was divided by the sum of the luminescence activity for control wells transfected with GL1-A and empty vector expressing the GL2 fragment alone (CtrlA) and with empty vector expressing the GL1 fragment alone and GL2-B (CtrlB). Thus, $\mathrm{NLR}=\mathrm{AB} /(\mathrm{Ctrl} \mathrm{A}+\mathrm{CtrlB})$. For each interaction, the final result was calculated from the mean NLR of at least triplicate experiments.

\section{RT-qPCR analysis of gene expression}

The analysis was performed using Applied Biosystem's StepOnePlusTM technology. The mRNA expression profiles in ST-LGP2 cells and ST-LGP2-C615A cells were determined by quantitative reverse transcription polymerase chain reaction (RT-qPCR) analysis of total RNA isolated with the RNeasy Mini Kit (\#72012, Qiagen). Reactions were performed with $100 \mathrm{ng}$ of RNA using TaqMan RNA-to-Ct 1-Step Kit (\#4392938, Thermo Fisher Scientific) and $1 \mu$ l of custom TaqMan Gene Expression Assays (Hs00225561_m1 for LGP2 and Hs99999905_m1 for GAPDH, Life Technologies). For IFN- $\beta$ or IFIT1 gene expression assays, total RNA was purified 24 hours after infection with MV. The relative amounts of IFN- $\beta$ or IFIT1 mRNAs were quantified by analogous one-step real-time PCR using GAPDH mRNA abundance as the internal control (IFN- $\beta$ \#Hs01077958_s1 
and IFIT1 \#Hs00356631_s1, Life Technologies). All of the measurements were performed in triplicate and analyzed as generated by the StepOnePlusTM software system. Results were normalized relative to the amount of GAPDH mRNA, and the amount of RLR mRNA in HEK293 cells was set to 1 . All of the measurements were performed in triplicate and analyzed with StepOnePlusTM software.

\section{ISRE reporter cells and MDA5/LGP2 cooperativity}

To determine the immunostimulatory activity when cotransfecting cells with plasmids encoding LGP2 and MDA5, ISRE reporter cell lines (STING-37 cells) were plated 1 day before transfection in 24 -well plates $\left(2 \times 10^{5}\right.$ cells per well). Plasmids (pCI-neo) encoding LGP2, or LGP2-C615A, or MDA5, or PACT were used in transfections separately or simultaneously using jetPRIME. All experiments were performed with a total of $250 \mathrm{ng}$ of DNA. Twenty-four hours after transfection, the cells were lysed with passive lysis buffer (\#E1941, Promega), and the Fluc activity was measured with the Bright-Glo Luciferase Assay System (\#E2638, Promega).

\section{ELISA analysis of the binding of MDA5, RIG-I, and LGP2 to PACT}

BL21-CodonPlus (DE3) cells transformed with pET15b (His-PACT) were used to express and purify PACT protein as previously described (67). Purified PACT $(1 \mu \mathrm{g} / \mathrm{ml})$ protein in 1X Dulbecco's PBS buffer (DPBS, Gibco) was bound to 96-well ELISA plates (200 ng per well) at $4^{\circ} \mathrm{C}$ overnight. The wells were washed with PBS containing $0.1 \%$ Tween 20 (PBS-T) three times at room temperature. The wells were then blocked with PBS-T containing 3\% nonfat dry milk for 1 hour at room temperature and washed three times with PBS-T. Double dilutions of STrEP-tag affinity purified MDA5, RIG-I, LGP2, and the negative control CH proteins were prepared in DPBS. The quantities of purified RLRs were controlled by Western blotting analysis. Each dilution of the RLR $(50 \mu \mathrm{l})$ was bound for 1 hour at $37^{\circ} \mathrm{C}$ to the wells coated with PACT and to the control uncoated wells. The latter were used to measure the nonspecific binding of each RLR. After the wells were washed, bound RLRs were detected with mouse anti-STrEP-tag (\#34850, Qiagen), followed by HRP-conjugated goat anti-mouse IgG and (\#115-035-146, Jackson ImmunoResearch). Colorimetric HRP substrate was added, and the amounts of bound RLRs were quantified by absorbance at $450 \mathrm{~nm}$ normalized to $620 \mathrm{~nm}$.

\section{Affinity chromatography of LGP2 and LGP2-C615A ribonucleoprotein complexes, subsequent RNA purification, and RT-qPCR analysis}

A previously described and validated protocol for the infection of ST-LGP2 and ST-LGP2-C615A cells with recombinant MV-CHIKV followed by STrEP-protein purification was applied (49). RNA extraction was performed directly from RNA-protein complexes eluted upon StrepTactin Sepharose affinity purification using TRI Reagent LS. RNA was extracted with the TRI Reagent LS before or after affinity chromatography purification on StrepTactin Sepharose. The 504-nt MV DI genome probe and primers were previously described (49). The extracted RNAs were analyzed using the nanodrop and Bioanalyzer RNA nano Kit before qPCR analysis. MV DI RNA RT-qPCR analysis was performed using Applied Biosystem StepOnePlu technology. Reactions were performed with $10 \mathrm{ng}$ of RNA using a TaqMan RNA-to-Ct 1-Step Kit for one-step RT-qPCR analyses. Reactions were performed in a final volume of $20 \mu \mathrm{l}$ in the presence of $100 \mathrm{nM}$ TaqMan MV DI-RNA probe and $250 \mathrm{nM}$ DIRNA forward (and reverse) primers.

\section{Statistical analysis}

The $\mathrm{R}$ environment was used for all of the analyses (68). Triplicate or quadruplicate values in each experimental condition were averaged. The data were then adjusted such that each independent experiment presented the same mean for HEK293 Mock (Fig. 1, B and C), HEK293 Mock (20 ng of RNA) (Fig. 1E), MV UV (Fig. 1F), RIG-IPACT A/B (Fig. 4C), LGP2 A/B (Fig. 5B), HEK293 (20 ng RNA) (Fig. 5, E and F, and Fig. 6C), HEK293 Mock (Fig. 5, G and H), mCherry (Fig. 6D), PACT (0 ng), LGP2 (0 ng) (Fig. 6E), RIG-IPACT Mock A/B (fig.S3, A and B), and SRRT LGP2 WT (fig. S4A). Data were also $\log _{2}$ converted before statistical analysis was performed. Statistical significance was set at $P \leq 0.05$. In each figure, type I error was controlled for by correcting the $P$ values according to the Benjamini \& Hochberg method ["BH" option in the p.adjust() function of R]. Data were analyzed using a linear model to take into account any potential interaction effects between the covariates. Two-by-two comparisons were performed using the contrast() function of the contrast package. The results are summarized in table S1.

\section{SUPPLEMENTARY MATERIALS}

stke.sciencemag.org/cgi/content/full/12/601/eaar3993/DC1 Fig. S1. Proteomics approach to study LGP2-specific protein partners.

Fig. S2. Assessment of RNA integrity within LGP2-protein complexes upon purification in the presence of RNaseA and RNaselll.

Fig. S3. PCA analysis of the binding of RIG-I and MDA5 to PACT in the presence of LGP2. Fig. S4. PCA analysis of the binding of the LGP2-C615A mutant with a known protein and with RNA binding partners of LGP2.

Table S1. Statistical analyses.

Table S2. List of direct and indirect LGP2-specific cellular partners identified by MS. Table S3. List of primers.

\section{REFERENCES AND NOTES}

1. G. Cheng, L.-C. Wang, Z. G. Fridlender, G. S. Cheng, B. Chen, N. S. Mangalmurti, V. Saloura, Z. Yu, V. Kapoor, K. Mozdzanowska, E. Moon, J. Sun, J. L. Kreindler, N. A. Cohen, A. J. Caton, J. Erikson, S. M. Albelda, Pharmacologic activation of the innate immune system to prevent respiratory viral infections. Am. J. Respir. Cell Mol. Biol. 45, 480-488 (2011).

2. S. Es-Saad, N. Tremblay, M. Baril, D. Lamarre, Regulators of innate immunity as novel targets for panviral therapeutics. Curr. Opin. Virol. 2, 622-628 (2012).

3. F. Guo, J. Mead, N. Aliya, L. Wang, A. Cuconati, L. Wei, K. Li, T. M. Block, J. T. Guo, J. Chang, RO 90-7501 enhances TLR3 and RLR agonist induced antiviral response. PLOS ONE 7, e42583 (2012).

4. M. Lucas-Hourani, D. Dauzonne, P. Jorda, G. Cousin, A. Lupan, O. Helynck, G. Caignard, G. Janvier, G. Andre-Leroux, S. Khiar, N. Escriou, P. Despres, Y. Jacob, H. Munier-Lehmann, F. Tangy, P. O. Vidalain, Inhibition of pyrimidine biosynthesis pathway suppresses viral growth through innate immunity. PLOS Pathog. 9, e1003678 (2013).

5. K. A. Shirey, Q. M. Nhu, K. C. Yim, Z. J. Roberts, J. R. Teijaro, D. L. Farber, J. C. Blanco, S. N. Vogel, The anti-tumor agent, 5,6-dimethylxanthenone-4-acetic acid (DMXAA), induces IFN-beta-mediated antiviral activity in vitro and in vivo. J. Leukoc. Biol. 89, 351-357 (2011).

6. E. Vasseur, E. Patin, G. Laval, S. Pajon, S. Fornarino, B. Crouau-Roy, L. Quintana-Murci, The selective footprints of viral pressures at the human RIG-I-like receptor family. Hum. Mol. Genet. 20, 4462-4474 (2011).

7. E. Dixit, J. C. Kagan, Intracellular pathogen detection by RIG-I-like receptors. Adv. Immunol. 117, 99-125 (2013).

8. Y. M. Loo, M. Gale Jr., Immune signaling by RIG-I-like receptors. Immunity 34, 680-692 (2011).

9. A. Komuro, C. M. Horvath, RNA- and virus-independent inhibition of antiviral signaling by RNA helicase LGP2. J. Virol. 80, 12332-12342 (2006).

10. A. M. Bruns, G. P. Leser, R. A. Lamb, C. M. Horvath, The innate immune sensor LGP2 activates antiviral signaling by regulating MDA5-RNA interaction and filament assembly. Mol. Cell 55, 771-781 (2014). 
11. S. Deddouche, D. Goubau, J. Rehwinkel, P. Chakravarty, S. Begum, P. V. Maillard, A. Borg, N. Matthews, Q. Feng, F. J. van Kuppeveld, C. Reis e Sousa, Identification of an LGP2-associated MDA5 agonist in picornavirus-infected cells. eLife 3, e01535 (2014).

12. R. Y. Sanchez David, C. Combredet, O. Sismeiro, M. A. Dillies, B. Jagla, J. Y. Coppee, M. Mura, M. Guerbois Galla, P. Despres, F. Tangy, A. V. Komarova, Comparative analysis of viral RNA signatures on different RIG-I-like receptors. eLife 5, (2016).

13. T. Venkataraman, M. Valdes, R. Elsby, S. Kakuta, G. Caceres, S. Saijo, Y. Iwakura, G. N. Barber, Loss of DExD/H box RNA helicase LGP2 manifests disparate antiviral responses. J. Immunol. 178, 6444-6455 (2007).

14. S. Rothenfusser, N. Goutagny, G. DiPerna, M. Gong, B. G. Monks, A. Schoenemeyer, M. Yamamoto, S. Akira, K. A. Fitzgerald, The RNA helicase Lgp2 inhibits TLR-independent sensing of viral replication by retinoic acid-inducible gene-I. J. Immunol. 175, 5260-5268 (2005).

15. T. Saito, R. Hirai, Y. M. Loo, D. Owen, C. L. Johnson, S. C. Sinha, S. Akira, T. Fujita, M. Gale Jr., Regulation of innate antiviral defenses through a shared repressor domain in RIG-I and LGP2. Proc. Natl. Acad. Sci. U.S.A. 104, 582-587 (2007).

16. M. Yoneyama, M. Kikuchi, K. Matsumoto, T. Imaizumi, M. Miyagishi, K. Taira, E. Foy, Y. M. Loo, M. Gale Jr., S. Akira, S. Yonehara, A. Kato, T. Fujita, Shared and unique functions of the DExD/H-box helicases RIG-I, MDA5, and LGP2 in antiviral innate immunity. J. Immunol. 175, 2851-2858 (2005).

17. D. Bamming, C. M. Horvath, Regulation of signal transduction by enzymatically inactive antiviral RNA helicase proteins MDA5, RIG-I, and LGP2. J. Biol. Chem. 284, 9700-9712 (2009).

18. S. Li, L. Wang, M. Berman, Y. Y. Kong, M. E. Dorf, Mapping a dynamic innate immunity protein interaction network regulating type I interferon production. Immunity $\mathbf{3 5}$, 426-440 (2011).

19. D. A. Pippig, J. C. Hellmuth, S. Cui, A. Kirchhofer, K. Lammens, A. Lammens, A. Schmidt, S. Rothenfusser, K. P. Hopfner, The regulatory domain of the RIG-I family ATPase LGP2 senses double-stranded RNA. Nucleic Acids Res. 37, 2014-2025 (2009).

20. T. Satoh, H. Kato, Y. Kumagai, M. Yoneyama, S. Sato, K. Matsushita, T. Tsujimura, T. Fujita, S. Akira, O. Takeuchi, LGP2 is a positive regulator of RIG-I- and MDA5-mediated antiviral responses. Proc. Natl. Acad. Sci. U.S.A. 107, 1512-1517 (2010)

21. M. S. Suthar, H. J. Ramos, M. M. Brassil, J. Netland, C. P. Chappell, G. Blahnik, A. McMillan, M. S. Diamond, E. A. Clark, M. J. Bevan, M. Gale Jr., The RIG-I-like receptor LGP2 controls $\mathrm{CD}^{+}{ }^{\mathrm{T}}$ cell survival and fitness. Immunity 37, 235-248 (2012).

22. D. Chopy, J. Pothlichet, M. Lafage, F. Mégret, L. Fiette, M. Si-Tahar, M. Lafon, Ambivalent role of the innate immune response in rabies virus pathogenesis. J. Virol. 85, 6657-6668 (2011).

23. M. Si-Tahar, F. Blanc, L. Furio, D. Chopy, V. Balloy, M. Lafon, M. Chignard, L. Fiette, F. Langa, P. Charneau, J. Pothlichet, Protective role of LGP2 in influenza virus pathogenesis. J. Infect. Dis. 210, 214-223 (2014).

24. A. V. Komarova, C. Combredet, L. Meyniel-Schicklin, M. Chapelle, G. Caignard, J. M. Camadro, V. Lotteau, P. O. Vidalain, F. Tangy, Proteomic analysis of virus-host interactions in an infectious context using recombinant viruses. Mol. Cell. Proteomics 10, M110.007443 (2011).

25. V. Hornung, J. Ellegast, S. Kim, K. Brzózka, A. Jung, H. Kato, H. Poeck, S. Akira, K. K. Conzelmann, M. Schlee, S. Endres, G. Hartmann, 5'-triphosphate RNA is the ligand for RIG-I. Science 314, 994-997 (2006).

26. H. Kato, O. Takeuchi, E. Mikamo-Satoh, R. Hirai, T. Kawai, K. Matsushita, A. Hiiragi, T. S. Dermody, T. Fujita, S. Akira, Length-dependent recognition of double-stranded ribonucleic acids by retinoic acid-inducible gene-I and melanoma differentiationassociated gene 5. J. Exp. Med. 205, 1601-1610 (2008).

27. A. M. Bruns, D. Pollpeter, N. Hadizadeh, S. Myong, J. F. Marko, C. M. Horvath, ATP hydrolysis enhances RNA recognition and antiviral signal transduction by the innate immune sensor, laboratory of genetics and physiology 2 (LGP2). J. Biol. Chem. 288, 938-946 (2013).

28. A. Baum, R. Sachidanandam, A. García-Sastre, Preference of RIG-I for short viral RNA molecules in infected cells revealed by next-generation sequencing. Proc. Natl. Acad. Sci. U.S.A. 107, 16303-16308 (2010).

29. S. Runge, K. M. Sparrer, C. Lassig, K. Hembach, A. Baum, A. Garcia-Sastre, J. Soding, K. K. Conzelmann, K. P. Hopfner, In vivo ligands of MDA5 and RIG-I in measles virus-infected cells. PLOS Pathog. 10, e1004081 (2014).

30. Q. Feng, S. V. Hato, M. A. Langereis, J. Zoll, R. Virgen-Slane, A. Peisley, S. Hur, B. L. Semler, R. P. van Rij, F. J. van Kuppeveld, MDA5 detects the double-stranded RNA replicative form in picornavirus-infected cells. Cell Rep. 2, 1187-1196 (2012).

31. L. Gitlin, W. Barchet, S. Gilfillan, M. Cella, B. Beutler, R. A. Flavell, M. S. Diamond, M. Colonna, Essential role of mda-5 in type IIFN responses to polyriboinosinic:polyribocytidylic acid and encephalomyocarditis picornavirus. Proc. Natl. Acad. Sci. U.S.A. 103, 8459-8464 (2006).

32. H. Kato, O. Takeuchi, S. Sato, M. Yoneyama, M. Yamamoto, K. Matsui, S. Uematsu, A. Jung, T. Kawai, K. J. Ishii, O. Yamaguchi, K. Otsu, T. Tsujimura, C. S. Koh, C. Reis e Sousa, Y. Matsuura, T. Fujita, S. Akira, Differential roles of MDA5 and RIG-I helicases in the recognition of RNA viruses. Nature 441, 101-105 (2006).
33. H. Fechner, S. Pinkert, A. Geisler, W. Poller, J. Kurreck, Pharmacological and biological antiviral therapeutics for cardiac coxsackievirus infections. Molecules 16, 8475-8503 (2011).

34. G. Dennis Jr., B. T. Sherman, D. A. Hosack, J. Yang, W. Gao, H. C. Lane, R. A. Lempicki, DAVID: Database for annotation, visualization, and integrated discovery. Genome Biol. 4, P3 (2003).

35. W. Huang da, B. T. Sherman, R. A. Lempicki, Systematic and integrative analysis of large gene lists using DAVID bioinformatics resources. Nat. Protoc. 4, 44-57 (2009).

36. P. Shannon, A. Markiel, O. Ozier, N. S. Baliga, J. T. Wang, D. Ramage, N. Amin, B. Schwikowski, T. Ideker, Cytoscape: A software environment for integrated models of biomolecular interaction networks. Genome Res. 13, 2498-2504 (2003).

37. C. R. MacKay, J. P. Wang, E. A. Kurt-Jones, Dicer's role as an antiviral: Still an enigma. Curr. Opin. Immunol. 26, 49-55 (2014).

38. A. Komuro, Y. Homma, T. Negoro, G. N. Barber, C. M. Horvath, The TAR-RNA binding protein is required for immunoresponses triggered by Cardiovirus infection. Biochem. Biophys. Res. Commun. 480, 187-193 (2016).

39. K. H. Kok, P. Y. Lui, M. H. Ng, K. L. Siu, S. W. Au, D. Y. Jin, The double-stranded RNA-binding protein PACT functions as a cellular activator of RIG-I to facilitate innate antiviral response. Cell Host Microbe 9, 299-309 (2011).

40. Z. Ding, L. Fang, S. Yuan, L. Zhao, X. Wang, S. Long, M. Wang, D. Wang, M. F. Foda, S. Xiao, The nucleocapsid proteins of mouse hepatitis virus and severe acute respiratory syndrome coronavirus share the same IFN- $\beta$ antagonizing mechanism: Attenuation of PACT-mediated RIG-I/ MDA5 activation. Oncotarget 8, 49655-49670 (2017).

41. P. Luthra, P. Ramanan, C. E. Mire, C. Weisend, Y. Tsuda, B. Yen, G. Liu, D. W. Leung, T. W. Geisbert, H. Ebihara, G. K. Amarasinghe, C. F. Basler, Mutual antagonism between the Ebola virus VP35 protein and the RIG-I activator PACT determines infection outcome. Cell Host Microbe 14, 74-84 (2013).

42. K. L. Siu, M. L. Yeung, K. H. Kok, K. S. Yuen, C. Kew, P. Y. Lui, C. P. Chan, H. Tse, P. C. Woo, K. Y. Yuen, D. Y. Jin, Middle east respiratory syndrome coronavirus 4a protein is a double-stranded RNA-binding protein that suppresses PACT-induced activation of RIG-I and MDA5 in the innate antiviral response. J. Virol. 88, 4866-4876 (2014).

43. P. Cassonnet, C. Rolloy, G. Neveu, P. O. Vidalain, T. Chantier, J. Pellet, L. Jones, M. Muller, C. Demeret, G. Gaud, F. Vuillier, V. Lotteau, F. Tangy, M. Favre, Y. Jacob, Benchmarking a luciferase complementation assay for detecting protein complexes. Nat. Methods $\mathbf{8}$, 990-992 (2011).

44. L. Hei, J. Zhong, Laboratory of genetics and physiology 2 (LGP2) plays an essential role in hepatitis $C$ virus infection-induced interferon responses. Hepatology 65, 1478-1491 (2017).

45. P. Y. Lui, L. R. Wong, T. H. Ho, S. W. N. Au, C. P. Chan, K. H. Kok, D. Y. Jin, PACT facilitates RNA-induced activation of MDA5 by promoting MDA5 oligomerization. J. Immunol. 199, 1846-1855 (2017).

46. E. G. Hitti, N. B. Sallacz, V. K. Schoft, M. F. Jantsch, Oligomerization activity of a doublestranded RNA-binding domain. FEBS Lett. 574, 25-30 (2004).

47. A. Peisley, C. Lin, B. Wu, M. Orme-Johnson, M. Liu, T. Walz, S. Hur, Cooperative assembly and dynamic disassembly of MDA5 filaments for viral dsRNA recognition. Proc. Natl. Acad. Sci. U.S.A. 108, 21010-21015 (2011).

48. B. Wu, A. Peisley, C. Richards, H. Yao, X. Zeng, C. Lin, F. Chu, T. Walz, S. Hur, Structural basis for dsRNA recognition, filament formation, and antiviral signal activation by MDA5. Cell 152, 276-289 (2013).

49. M. Mura, C. Combredet, V. Najburg, R. Y. Sanchez David, F. Tangy, A. V. Komarova, Non-encapsidated 5 ' copy-back defective-interfering genomes produced by recombinant measles viruses are recognized by RIG-I and LGP2 but not MDA5. J. Virol. 91 , e00643-17 (2017).

50. D. Luo, S. C. Ding, A. Vela, A. Kohlway, B. D. Lindenbach, A. M. Pyle, Structural insights into RNA recognition by RIG-I. Cell 147, 409-422 (2011).

51. A. Ashe, T. Bélicard, J. Le Pen, P. Sarkies, L. Frezal, N. J. Lehrbach, M. A. Felix, E. A. Miska, A deletion polymorphism in the Caenorhabditis elegans RIG-I homolog disables viral RNA dicing and antiviral immunity. eLife 2, e00994 (2013).

52. X. Guo, R. Zhang, J. Wang, S. W. Ding, R. Lu, Homologous RIG-l-like helicase proteins direct RNAi-mediated antiviral immunity in C. elegans by distinct mechanisms. Proc. Natl. Acad. Sci. U.S.A. 110, 16085-16090 (2013).

53. A. Heyam, D. Lagos, M. Plevin, Dissecting the roles of TRBP and PACT in double-stranded RNA recognition and processing of noncoding RNAs. Wiley Interdiscip. Rev. RNA 6, 271-289 (2015).

54. R. C. Patel, G. C. Sen, PACT, a protein activator of the interferon-induced protein kinase, PKR. EMBO J. 17, 4379-4390 (1998).

55. A. G. van der Veen, P. V. Maillard, J. M. Schmidt, S. A. Lee, S. Deddouche-Grass, A. Borg, S. Kjaer, A. P. Snijders, E. S. C. Reis, The RIG-l-like receptor LGP2 inhibits Dicer-dependent processing of long double-stranded RNA and blocks RNA interference in mammalian cells. EMBO J. 37, e97479 (2018).

56. M. Miyamoto, A. Komuro, PACT is required for MDA5-mediated immunoresponses triggered by Cardiovirus infection via interaction with LGP2. Biochem. Biophys. Res. Commun. 494, 227-233 (2017). 
57. Y. del Toro Duany, B. Wu, S. Hur, MDA5-filament, dynamics and disease. Curr. Opin. Virol. 12, 20-25 (2015)

58. G. I. Rice, Y. del Toro Duany, E. M. Jenkinson, G. M. A. Forte, B. H. Anderson, G. Ariaudo, B. Bader-Meunier, E. M. Baildam, R. Battini, M. W. Beresford, M. Casarano, M. Chouchane, R. Cimaz, A. E. Collins, N. J. V. Cordeiro, R. C. Dale, J. E. Davidson, L. de Waele, I. Desguerre, L. Faivre, E. Fazzi, B. Isidor, L. Lagae, A. R. Latchman, P. Lebon, C. Li, J. H. Livingston, C. M. Lourenço, M. M. Mancardi, A. Masurel-Paulet, I. B. Mclnnes, M. P. Menezes, C. Mignot, J. O'Sullivan, S. Orcesi, P. P. Picco, E. Riva, R. A. Robinson, D. Rodriguez, E. Salvatici, C. Scott, M. Szybowska, J. L. Tolmie, A. Vanderver, C. Vanhulle, J. P. Vieira, K. Webb, R. N. Whitney, S. G. Williams, L. A. Wolfe, S. M. Zuberi, S. Hur, Y. J. Crow, Gain-of-function mutations in IFIH1 cause a spectrum of human disease phenotypes associated with upregulated type I interferon signaling. Nat. Genet. 46, 503-509 (2014).

59. B. R. tenOever, Questioning antiviral RNAi in mammals. Nat. Microbiol. 2, 17052 (2017).

60. P. V. Maillard, A. G. Van der Veen, S. Deddouche-Grass, N. C. Rogers, A. Merits, E. S. C. Reis, Inactivation of the type I interferon pathway reveals long double-stranded RNAmediated RNA interference in mammalian cells. EMBO J. 35, 2505-2518 (2016).

61. H. Yao, M. Dittmann, A. Peisley, H. H. Hoffmann, R. H. Gilmore, T. Schmidt, J. L. Schmid-Burgk, V. Hornung, C. M. Rice, S. Hur, ATP-dependent effector-like functions of RIG-I-like receptors. Mol. Cell 58, 541-548 (2015).

62. C. Combredet, V. Labrousse, L. Mollet, C. Lorin, F. Delebecque, B. Hurtrel, H. McClure, M. B. Feinberg, M. Brahic, F. Tangy, A molecularly cloned Schwarz strain of measles virus vaccine induces strong immune responses in macaques and transgenic mice. J. Virol. 77, 11546-11554 (2003).

63. S. Brandler, C. Ruffié, C. Combredet, J. B. Brault, V. Najburg, M. C. Prevost, A. Habel, E. Tauber, P. Despres, F. Tangy, A recombinant measles vaccine expressing chikungunya virus-like particles is strongly immunogenic and protects mice from lethal challenge with chikungunya virus. Vaccine 31, 3718-3725 (2013).

64. G. M. Duke, J. E. Osorio, A. C. Palmenberg, Attenuation of Mengo virus through genetic engineering of the 5' noncoding poly(C) tract. Nature 343, 474-476 (1990).

65. R. Lin, P. Genin, Y. Mamane, J. Hiscott, Selective DNA binding and association with the CREB binding protein coactivator contribute to differential activation of alpha/ beta interferon genes by interferon regulatory factors 3 and 7. Mol. Cell. Biol. 20, 6342-6353 (2000).

66. T. Reuter, B. Weissbrich, S. Schneider-Schaulies, J. Schneider-Schaulies, RNA interference with measles virus $N, P$, and $L$ mRNAs efficiently prevents and with matrix protein mRNA enhances viral transcription. J. Virol. 80, 5951-5957 (2006).

67. S. Dabo, P. Maillard, M. Collados Rodriguez, M. D. Hansen, S. Mazouz, D. J. Bigot, M. Tible, G. Janvier, O. Helynck, P. Cassonnet, Y. Jacob, J. Bellalou, A. Gatignol, R. C. Patel, J. Hugon, H. Munier-Lehmann, E. F. Meurs, Inhibition of the inflammatory response to stress by targeting interaction between PKR and its cellular activator PACT. Sci. Rep. 7, 16129 (2017).
68. J. A. Vizcaino, R. G. Côté, A. Csordas, J. A. Dianes, A. Fabregat, J. M. Foster, J. Griss, E. Alpi, M. Birim, J. Contell, G. O’Kelly, A. Schoenegger, D. Ovelleiro, Y. Pérez-Riverol, F. Reisinger, D. Ríos, R. Wang, H. Hermjakob, The PRoteomics IDEntifications (PRIDE) database and associated tools: status in 2013. Nucleic Acids Res. 41, D1063-D1069 (2013).

Acknowledgments: We thank A. Zhukova (Evolutionary Bioinformatics/Bioinformatics and Biostatistics Hub, C3BI, Institut Pasteur) and F. Gwinner (Systems Biology Laboratory, Institut Pasteur, Paris) for their help with bioinformatics analysis of the MS data. We thank N. Escriou (Unité de Génomique Virale et Vaccination) for the mengovirus stock, E. Meurs (Unité de Hépacivirus et immunité innée, Institut Pasteur) for the antibody against PKR, G. Moratorio (Institut Pasteur Montevideo) for the coxsackie virus stock, the CCSB DFCl for providing clones from the Human ORFeome Collection, and M. Nowakowski (Platform of Recombinant Proteins in Prokaryotic Cells, Institut Pasteur) for PACT protein purification. We thank N. Vabret for critical reading of the manuscript. We acknowledge all the members of the Unité de Génomique Virale et Vaccination at Pasteur Institute, and especially N. Escriou, for their help and useful discussions. Funding: This study was supported by the Institut Pasteur and the CNRS. R.Y.S.D. was supported by the Fondation pour la Recherche Médicale (FDT20140931129). We thank the Region lle-de-France (SESAME), the Paris-Diderot University (ARS), and CNRS for funding part of the LC-MS/MS equipment of the proteomics core facility at the Institut Jacques-Monod. Author contributions: R.Y.S.D., C.C., and A.V.K. designed the experiments. R.Y.S.D., C.C., and V.N. performed the experiments under the supervision of A.V.K. and F.T. G.A.M. performed independent statistical analysis of all the data. T.L. and J.-M.C. performed MS analysis. B.S. helped with Cytoscape and Y.J. helped with the PCA analyses. J.B. supervised the expression and purification of PACT protein. G.B. and N.J. contributed to the ELISA and PCA data analyses and discussion of the results. R.Y.S.D., F.T., and A.V.K. conceived and wrote the manuscript, whereas all authors endorse its content. Competing interests: The authors declare that they have no competing interests. Data and materials availability: The complete MS datasets are available in the PRIDE partner repository (68) under the identification no. PXD013191 as .raw files and associated pep.xml and .xlsx files. All other data needed to evaluate the conclusions in the paper are present in the paper and the Supplementary Materials.

Submitted 10 November 2017

Resubmitted 17 October 2018

Accepted 13 September 2019

Published 1 October 2019

10.1126/scisignal.aar3993

Citation: R. Y. Sanchez David, C. Combredet, V. Najburg, G. A. Millot, G. Beauclair, B. Schwikowski, T. Léger, J.-M. Camadro, Y. Jacob, J. Bellalou, N. Jouvenet, F. Tangy, A. V. Komarova, LGP2 binds to PACT to regulate RIG-I- and MDA5-mediated antiviral responses. Sci. Signal. 12, eaar3993 (2019). 


\section{ScienceSignaling}

\section{LGP2 binds to PACT to regulate RIG-I- and MDA5-mediated antiviral responses}

Raul Y. Sanchez David, Chantal Combredet, Valérie Najburg, Gael A. Millot, Guillaume Beauclair, Benno Schwikowski, Thibaut Léger, Jean-Michel Camadro, Yves Jacob, Jacques Bellalou, Nolwenn Jouvenet, Frédéric Tangy and Anastassia V. Komarova

Sci. Signal. 12 (601), eaar3993.

DOI: $10.1126 /$ scisignal.aar3993

\section{An antiviral PACT}

The RIG-I-like receptors (RLRs) RIG-I and MDA5 sense cytosolic viral RNAs during infection and activate signaling pathways that culminate in the production of type I interferons (IFNs) and proinflammatory cytokines as part of the antiviral immune response. LGP2, another member of the RLR family, inhibits RIG-I-mediated responses while enhancing MDA5 signaling. Sanchez David et al. found that this differential effect of LGP2 depended on its binding to PACT, a cofactor of DICER in the processing of microRNAs. Mutation of a residue in LGP2 required for the LGP2-PACT interaction resulted in loss of the regulatory effect of LGP2 over the other RLRs. Together, these data provide evidence of a connection between the RNA-silencing machinery and the innate immune response.

ARTICLE TOOLS

SUPPLEMENTARY MATERIALS

RELATED

CONTENT

REFERENCES

PERMISSIONS http://stke.sciencemag.org/content/12/601/eaar3993

http://stke.sciencemag.org/content/suppl/2019/09/27/12.601.eaar3993.DC1

http://stke.sciencemag.org/content/sigtrans/10/509/eaan2392.full http://stke.sciencemag.org/content/sigtrans/10/460/eaae0435.full $\mathrm{http}: / / \mathrm{stm}$.sciencemag.org/content/scitransmed/9/386/eaag2513.ful http://science.sciencemag.org/content/sci/365/6454/eaav0758.full

This article cites 67 articles, 26 of which you can access for free http://stke.sciencemag.org/content/12/601/eaar3993\#BIBL

http://www.sciencemag.org/help/reprints-and-permissions

Use of this article is subject to the Terms of Service

Science Signaling (ISSN 1937-9145) is published by the American Association for the Advancement of Science, 1200 New York Avenue NW, Washington, DC 20005. 2017 (C) The Authors, some rights reserved; exclusive licensee American Association for the Advancement of Science. No claim to original U.S. Government Works. The title Science Signaling is a registered trademark of AAAS. 


\title{
Science Signaling
}

MIAAAS

stke.sciencemag.org/cgi/content/full/12/601/eaar3993/DC1

\section{Supplementary Materials for}

\section{LGP2 binds to PACT to regulate RIG-I- and MDA5-mediated antiviral responses}

\author{
Raul Y. Sanchez David, Chantal Combredet, Valérie Najburg, Gael A. Millot, Guillaume Beauclair, Benno Schwikowski, \\ Thibaut Léger, Jean-Michel Camadro, Yves Jacob, Jacques Bellalou, Nolwenn Jouvenet, \\ Frédéric Tangy*, Anastassia V. Komarova* \\ *Corresponding author. Email: frederic.tangy@pasteur.fr (F.T.); stasy@pasteur.fr (A.V.K.) \\ Published 1 October 2019, Sci. Signal. 12, eaar3993 (2019) \\ DOI: 10.1126/scisignal.aar3993
}

\section{This PDF file includes:}

Fig. S1. Proteomics approach to study LGP2-specific protein partners.

Fig. S2. Assessment of RNA integrity within LGP2-protein complexes upon purification in the presence of RNaseA and RNaseIII.

Fig. S3. PCA analysis of the binding of RIG-I and MDA5 to PACT in the presence of LGP2.

Fig. S4. PCA analysis of the binding of the LGP2-C615A mutant with a known protein and with RNA binding partners of LGP2.

Table S1. Statistical analyses.

Table S2. List of direct and indirect LGP2-specific cellular partners identified by MS.

Table S3. List of primers. 
A

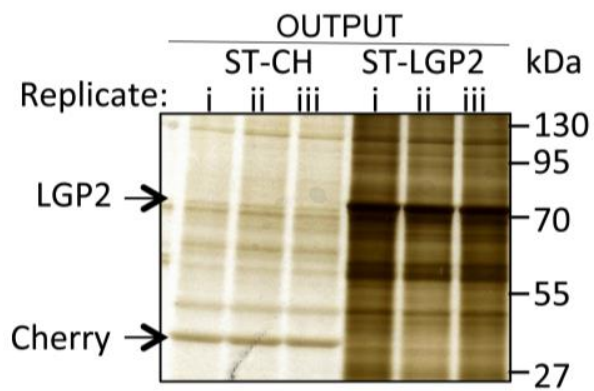

B

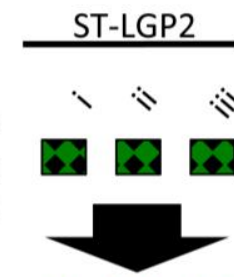

尊

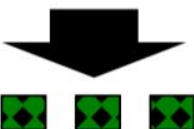

1.LC-MS/MS:
Only peptides with ion score $>30$

retained

2.Human protein analysis:

Swissprot query

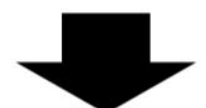

3.Filtering background: triage according to protein score

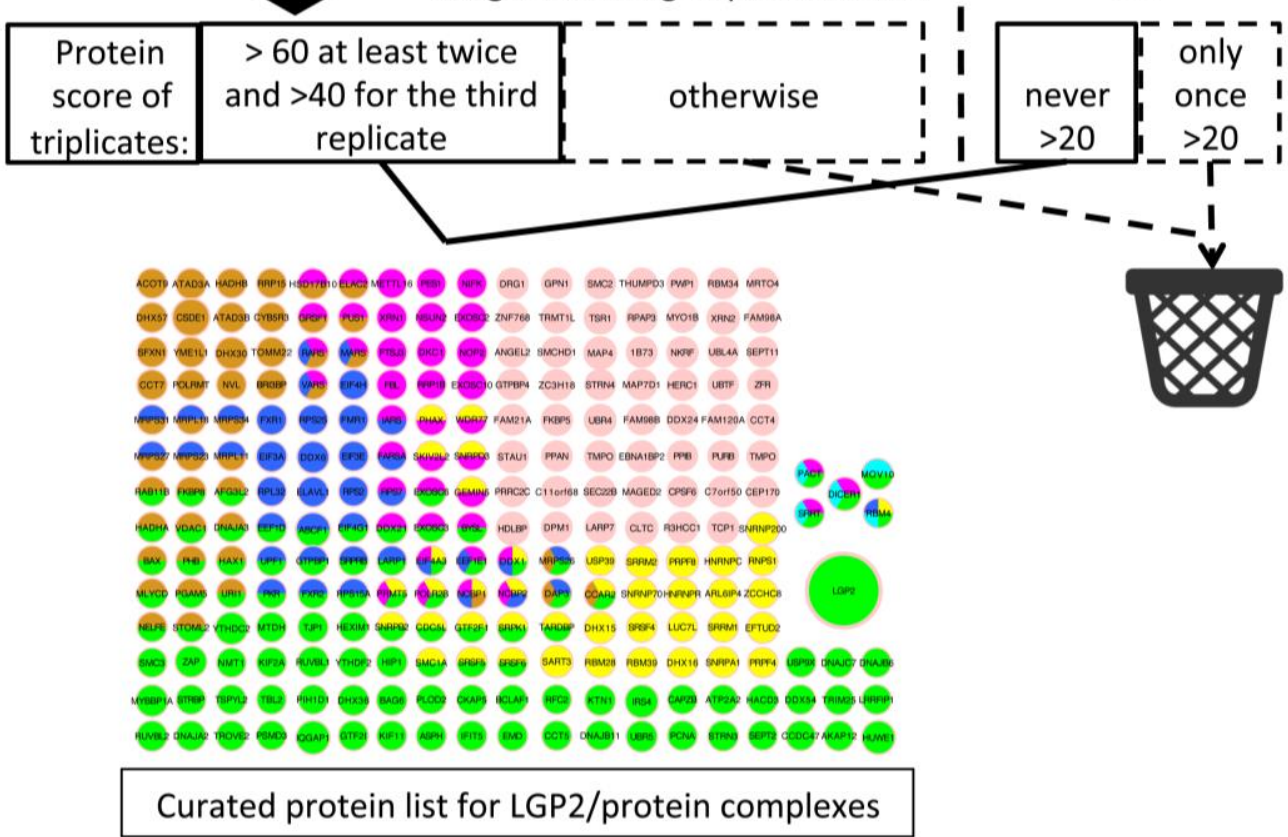

Fig. S1. Proteomics approach to study LGP2-specific protein partners. (A) Silver staining of the affinity chromatography-purified LGP2- and CH-specific proteins. LGP2- and CH-specific proteins were purified from mock-infected cells. Experiments were performed in triplicate (i, ii, and iii). (B) Schematic representation of the proteomics data-filtering steps. RLR/protein complexes were subjected to LC-MS/MS analysis, the peptides were identified were queried on the Swissprot database, and finally the background was removed by different protein score settings. 

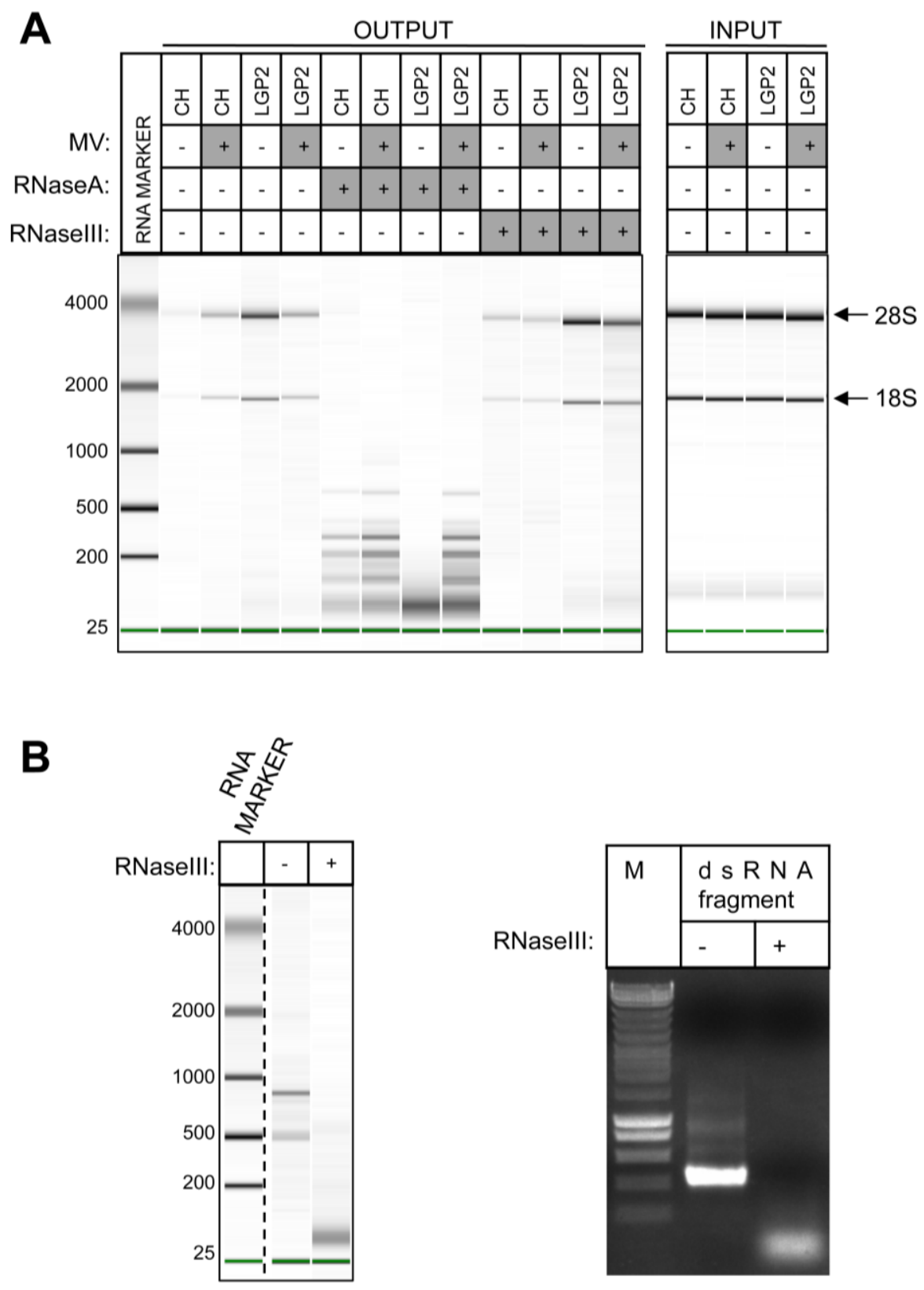

Fig. S2. Assessment of RNA integrity within LGP2-protein complexes upon purification in the presence of RNaseA and RNaseIII. (A) An aliquot of each sample presented in Fig. 3B was used for RNA extraction. Extracted RNAs were analyzed by Agilent microcapillary electrophoresis. The positions of rRNAs are shown with arrows. One representative experiment of two biological replicates is represented. (B) The RNaseIII control digestion test performed on in vitro-transcribed dsRNA under experimental conditions identical to those for Fig. 3B and visualized by Agilent microcapillary electrophoresis (left) and by electrophoresis on a $1 \%$ agarose gel (right). M, DNA marker. Dashed vertical line indicates noncontiguous lanes. 
A

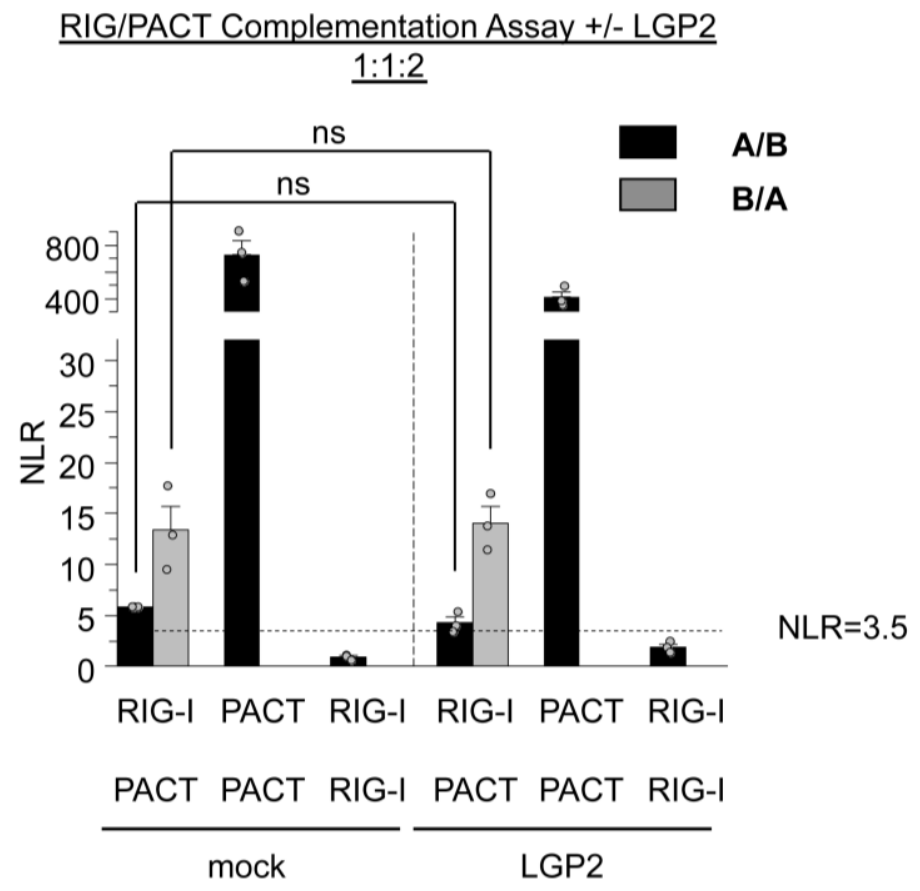

B

MDA5/PACT Complementation Assay +/- LGP2

$\underline{1: 1: 2}$

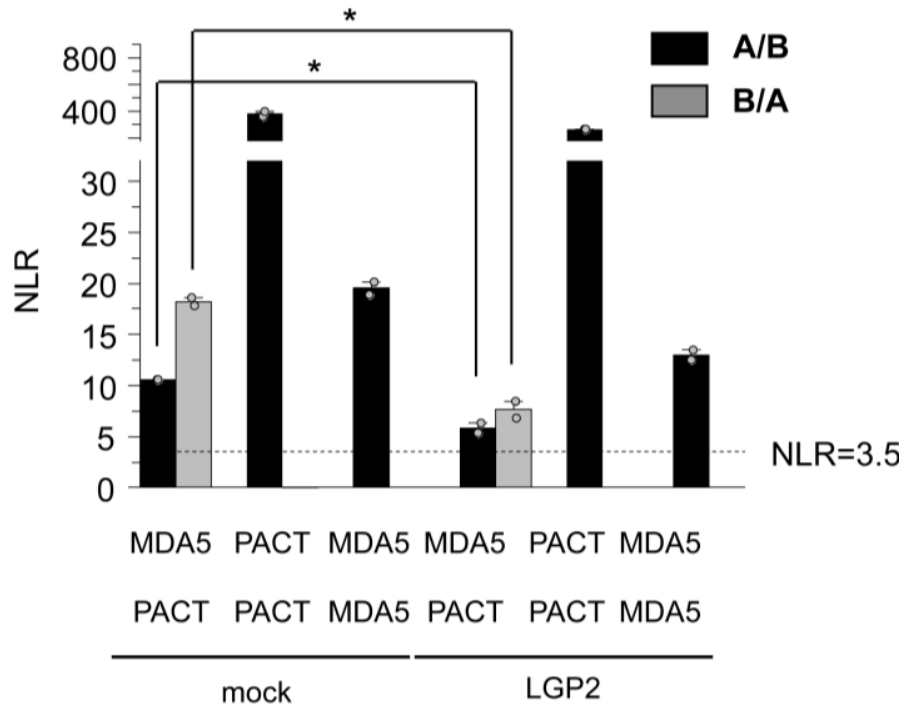

Fig. S3. PCA analysis of the binding of RIG-I and MDA5 to PACT in the presence of LGP2. (A and B) HEK293T cells were co-transfected with plasmids encoding RIG-I (A) or MDA5 (B) and with plasmid encoding PACT in the presence of WT LGP2 expressed from the third plasmid in a mass concentration ratio of 1:1:2 for RIG-I/MDA5:PACT:LGP2. Empty vector was used as a negative control (mock). Black and gray bars correspond to the same experimental set-up that was used for Fig. 4C. Data are means \pm SEM of three (A) or two (B) independent experiments. ${ }^{*} P \leq 0.05$; ns, not significant. See table $\mathrm{S} 1$ for all details on statistics. 
A
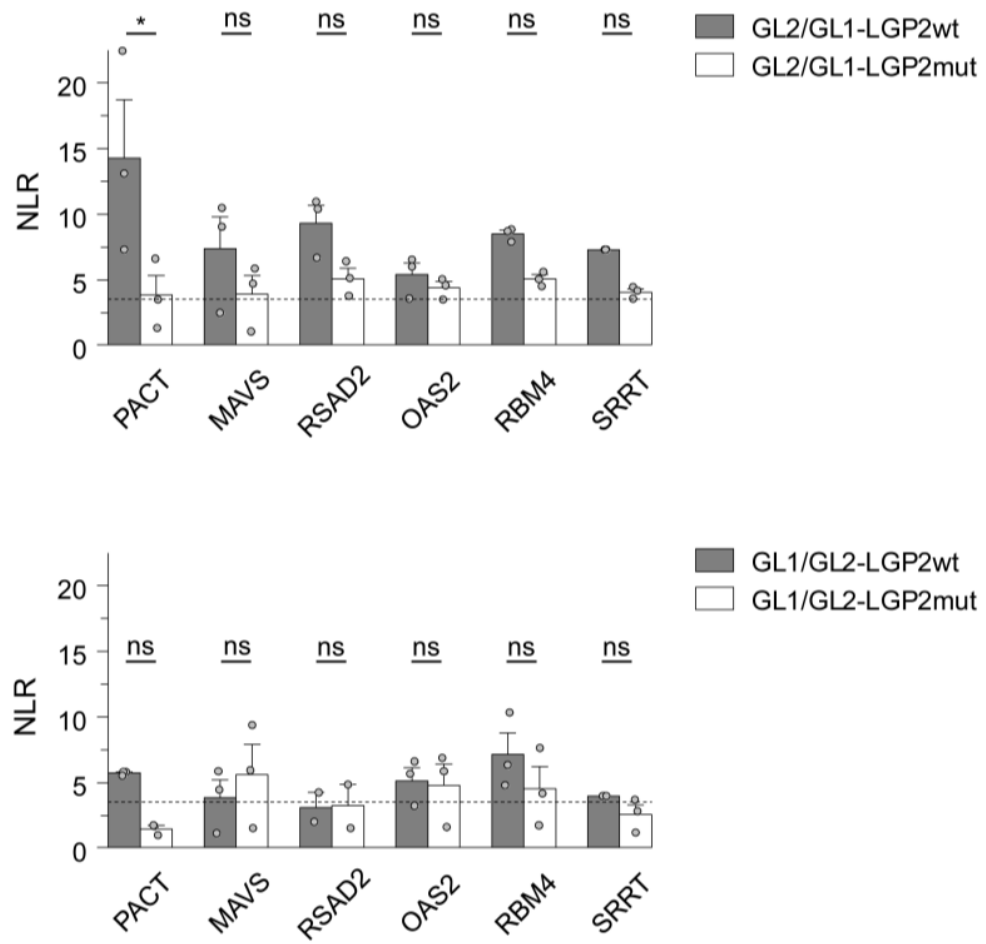

B

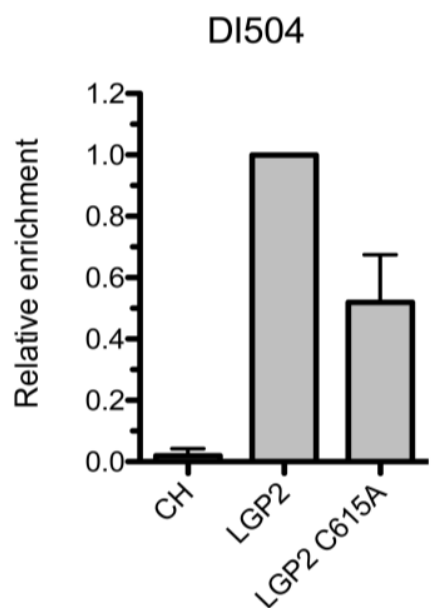

Fig. S4. PCA analysis of the binding of the LGP2-C615A mutant with a known protein and with RNA binding partners of LGP2. (A) HEK293T cells were co-transfected with plasmids encoding LGP2 WT or LGP2C615A, as well as with plasmids encoding seven known partners of LGP2. The gray and white columns correspond to NLRs where respectively LGP2 WT (gray) or LGP2-C615A (white) were fused to the GL1 (Nter-Luc) and the host protein was fused to the GL2 (Cter-Luc) or where LGP2 WT or LGP2-C615A were fused to the GL2 and the host protein was fused to the GL1. Data are means \pm SEM of three independent experiments. The asterisk indicates a statistically significant difference of effect (contrast test) in NLR; ns, no significant difference. See table S1 for all details on statistics. (B) The LGP2 C615A mutant maintains its ability to bind to DI504. Fold-enrichment of DI504 genome over the WT LGP2 sample were normalized by Beads/Total ratio and by immunoprecipitation efficiency as calculated by Western blotting using LI-COR technology. Data are means and SD of two biological replicates. 
Table S1. Statistical analyses. List of the statistical analyses performed on the data represented in Figs. 1B, $1 \mathrm{C}, 1 \mathrm{E}, 5 \mathrm{~B}, 5 \mathrm{G}, 5 \mathrm{H}, 6 \mathrm{D}$, and $6 \mathrm{E}$ and figs. S3A, S3B, and S4A. Figure number, compared samples, type of comparison, sample size (n) and degree of freedom (df) for each class tested, the type of test applied for statistical analysis, the $P$ value, and the adjusted $P$ value according to Benjamini and Hochberg are indicated.

\begin{tabular}{|c|c|c|c|c|c|c|}
\hline Figure & Comparison & $\begin{array}{l}\text { Alternative } \\
\text { hypothesis }\end{array}$ & Sample size & Test & $P$ value & $\begin{array}{l}\text { Adjusted } \\
P \text { value }\end{array}$ \\
\hline \multirow{4}{*}{ 1B } & $\begin{array}{l}\text { HEK293 and ST-LGP2 } \\
\text { in Mock }\end{array}$ & $\begin{array}{c}\text { Mean } \\
\text { difference }\end{array}$ & $\begin{array}{l}\mathrm{n}_{\text {HEK293 }}=5, \mathrm{n}_{\mathrm{ST}-} \\
\text { LGP2 }=5, \mathrm{df}=32\end{array}$ & $\begin{array}{l}\text { Contrast test in } \\
\text { linear model }\end{array}$ & 0.88 & 0.88 \\
\hline & $\begin{array}{l}\text { HEK293 and ST-LGP2 } \\
\text { in 5'3P }\end{array}$ & $\begin{array}{c}\text { Mean } \\
\text { difference }\end{array}$ & $\begin{array}{l}\mathrm{n}_{\text {HEK293 }}=5, \mathrm{n}_{\text {ST- }} \\
\text { LGP2 }=5, \mathrm{df}=32\end{array}$ & $\begin{array}{l}\text { Contrast test in } \\
\text { linear model }\end{array}$ & 0.001 & 0.002 \\
\hline & $\begin{array}{c}\text { HEK293 and ST-LGP2 } \\
\text { in LMW }\end{array}$ & $\begin{array}{c}\text { Mean } \\
\text { difference }\end{array}$ & $\begin{array}{l}\mathrm{n}_{\text {HEK } 293}=5, \mathrm{n}_{\mathrm{ST}-} \\
\text { LGP2 }=5, \mathrm{df}=32\end{array}$ & $\begin{array}{l}\text { Contrast test in } \\
\text { linear model }\end{array}$ & 0.004 & 0.005 \\
\hline & $\begin{array}{c}\text { HEK293 and ST-LGP2 } \\
\text { in HMW }\end{array}$ & $\begin{array}{c}\text { Mean } \\
\text { difference }\end{array}$ & $\begin{array}{l}\mathrm{n}_{\text {HEK293 }}=5, \mathrm{n}_{\mathrm{ST}-} \\
\text { LGP2 }=5, \mathrm{df}=32\end{array}$ & $\begin{array}{l}\text { Contrast test in } \\
\text { linear model }\end{array}$ & $3 e-5$ & $1 e-4$ \\
\hline \multirow{4}{*}{$1 \mathrm{C}$} & $\begin{array}{c}\text { HEK293 and ST-LGP2 } \\
\text { in Mock }\end{array}$ & $\begin{array}{c}\text { Mean } \\
\text { difference }\end{array}$ & $\begin{array}{l}\mathrm{n}_{\text {HEK293 }}=5, n_{\text {ST- }} \\
\text { LGP2 }=5, d f=32\end{array}$ & $\begin{array}{l}\text { Contrast test in } \\
\text { linear model }\end{array}$ & 0.36 & 0.36 \\
\hline & $\begin{array}{c}\text { HEK293 and ST-LGP2 } \\
\text { in 5'3P }\end{array}$ & $\begin{array}{c}\text { Mean } \\
\text { difference }\end{array}$ & $\begin{array}{l}\mathrm{n}_{\text {HEK } 293}=5, \mathrm{n}_{\mathrm{ST}-} \\
\text { LGP2 }=5, \mathrm{df}=32\end{array}$ & $\begin{array}{l}\text { Contrast test in } \\
\text { linear model }\end{array}$ & 0.006 & 0.012 \\
\hline & $\begin{array}{l}\text { HEK293 and ST-LGP2 } \\
\text { in LMW }\end{array}$ & $\begin{array}{c}\text { Mean } \\
\text { difference }\end{array}$ & $\begin{array}{l}\mathrm{n}_{\text {HEK293 }}=5, \mathrm{n}_{\text {ST- }} \\
\text { LGP2 }=5, \mathrm{df}=32\end{array}$ & $\begin{array}{l}\text { Contrast test in } \\
\text { linear model }\end{array}$ & 0.11 & 0.15 \\
\hline & $\begin{array}{l}\text { HEK293 and ST-LGP2 } \\
\text { in HMW }\end{array}$ & $\begin{array}{c}\text { Mean } \\
\text { difference }\end{array}$ & $\begin{array}{l}\mathrm{n}_{\text {HEK } 293}=5, \mathrm{n}_{\mathrm{ST}-} \\
\text { LGP2 }=5, \mathrm{df}=32\end{array}$ & $\begin{array}{l}\text { Contrast test in } \\
\text { linear model }\end{array}$ & $2 e-4$ & $6 e-4$ \\
\hline \multirow{10}{*}{$1 \mathrm{E}$} & $\begin{array}{c}\text { HEK293 and ST-LGP2 } \\
20 \mathrm{ng} \text { in MV }\end{array}$ & $\begin{array}{c}\text { Mean } \\
\text { difference }\end{array}$ & $\begin{array}{l}\mathrm{n}_{\text {HEK293 }}=3, \mathrm{n}_{\mathrm{ST}-} \\
\text { LGP2 }=3, \mathrm{df}=8\end{array}$ & $\begin{array}{l}\text { Contrast test in } \\
\text { linear model }\end{array}$ & 0.008 & 0.01 \\
\hline & $\begin{array}{c}\text { HEK293 and ST-LGP2 } \\
100 \mathrm{ng} \text { in MV }\end{array}$ & $\begin{array}{c}\text { Mean } \\
\text { difference }\end{array}$ & $\begin{array}{l}\mathrm{n}_{\text {HEK293 }}=3, \mathrm{n}_{\mathrm{ST}-} \\
\mathrm{LGP} 2=3, \mathrm{df}=8\end{array}$ & $\begin{array}{l}\text { Contrast test in } \\
\text { linear model }\end{array}$ & $5 e-5$ & $5 e-4$ \\
\hline & $\begin{array}{l}\text { HEK293 and ST-LGP2 } \\
20 \text { ng in DMSO Mengo }\end{array}$ & $\begin{array}{c}\text { Mean } \\
\text { difference }\end{array}$ & $\begin{array}{l}\mathrm{n}_{\text {HEK293 }}=3, \mathrm{n}_{\mathrm{ST}-} \\
\text { LGP2 }=3, \mathrm{df}=8\end{array}$ & $\begin{array}{l}\text { Contrast test in } \\
\text { linear model }\end{array}$ & 0.003 & 0,01 \\
\hline & $\begin{array}{c}\text { HEK293 and ST-LGP2 } \\
100 \mathrm{ng} \text { in DMSO } \\
\text { Mengo }\end{array}$ & $\begin{array}{c}\text { Mean } \\
\text { difference }\end{array}$ & $\begin{array}{l}\mathrm{n}_{\mathrm{HEK} 293}=3, \mathrm{n}_{\mathrm{ST}-} \\
\mathrm{LGP2}=3, \mathrm{df}=8\end{array}$ & $\begin{array}{l}\text { Contrast test in } \\
\text { linear model }\end{array}$ & 0.12 & 0,15 \\
\hline & $\begin{array}{c}\text { HEK293 and ST-LGP2 } \\
20 \text { ng in Riba Mengo }\end{array}$ & $\begin{array}{c}\text { Mean } \\
\text { difference }\end{array}$ & $\begin{array}{l}\mathrm{n}_{\text {HEK293 }}=3, \mathrm{n}_{\mathrm{ST}-} \\
\text { LGP2 }=3, \mathrm{df}=8\end{array}$ & $\begin{array}{l}\text { Contrast test in } \\
\text { linear model }\end{array}$ & 0.09 & 0.13 \\
\hline & $\begin{array}{l}\text { HEK293 and ST-LGP2 } \\
100 \text { ng in Riba Mengo }\end{array}$ & $\begin{array}{c}\text { Mean } \\
\text { difference }\end{array}$ & $\begin{array}{l}\mathrm{n}_{\text {HEK293 }}=3, \mathrm{n}_{\mathrm{ST}-} \\
\text { LGP2 }=3, \mathrm{df}=8\end{array}$ & $\begin{array}{c}\text { Contrast test in } \\
\text { linear model }\end{array}$ & 0.05 & 0.08 \\
\hline & $\begin{array}{l}\text { HEK293 and ST-LGP2 } \\
20 \text { ng in DMSO Cox }\end{array}$ & $\begin{array}{c}\text { Mean } \\
\text { difference }\end{array}$ & $\begin{array}{l}\mathrm{n}_{\text {HEK293 }}=3, \mathrm{n}_{\mathrm{ST}-} \\
\text { LGP2 }=3, \mathrm{df}=8\end{array}$ & $\begin{array}{l}\text { Contrast test in } \\
\text { linear model }\end{array}$ & 0.003 & 0,01 \\
\hline & $\begin{array}{c}\text { HEK293 and ST-LGP2 } \\
100 \text { ng in DMSO Cox }\end{array}$ & $\begin{array}{c}\text { Mean } \\
\text { difference }\end{array}$ & $\begin{array}{l}\mathrm{n}_{\text {HEK293 }}=3, \mathrm{n}_{\mathrm{ST}-} \\
\text { LGP2 }=3, \mathrm{df}=8\end{array}$ & $\begin{array}{l}\text { Contrast test in } \\
\text { linear model }\end{array}$ & 0.005 & 0,01 \\
\hline & $\begin{array}{c}\text { HEK293 and ST-LGP2 } \\
20 \text { ng in Riba Cox }\end{array}$ & $\begin{array}{c}\text { Mean } \\
\text { difference }\end{array}$ & $\begin{array}{l}\mathrm{n}_{\mathrm{HEK} 293}=3, \mathrm{n}_{\mathrm{ST}-} \\
\text { LGP2 }=3, \mathrm{df}=8\end{array}$ & $\begin{array}{l}\text { Contrast test in } \\
\text { linear model }\end{array}$ & 0.17 & 0.19 \\
\hline & $\begin{array}{c}\text { HEK293 and ST-LGP2 } \\
100 \text { ng in Riba Cox }\end{array}$ & $\begin{array}{c}\text { Mean } \\
\text { difference }\end{array}$ & $\begin{array}{l}\mathrm{n}_{\text {HEK293 }}=3, \mathrm{n}_{\mathrm{ST}-} \\
\text { LGP2 }=3, \mathrm{df}=8\end{array}$ & $\begin{array}{l}\text { Contrast test in } \\
\text { linear model }\end{array}$ & 0.46 & 0.46 \\
\hline \multirow{4}{*}{$5 B$} & $\begin{array}{l}\text { LGP2-WT and LGP2- } \\
\text { C615A in A/B }\end{array}$ & $\begin{array}{c}\text { Mean } \\
\text { difference }\end{array}$ & $\begin{array}{l}n_{\mathrm{WT}}=2, \mathrm{n}_{\mathrm{C} 615 \mathrm{~A}}= \\
2, \mathrm{df}=8\end{array}$ & $\begin{array}{l}\text { Contrast test in } \\
\text { linear model }\end{array}$ & 0.05 & 0.05 \\
\hline & $\begin{array}{c}\text { LGP2-WT and LGP2- } \\
\text { C615A in B/A }\end{array}$ & $\begin{array}{c}\text { Mean } \\
\text { difference }\end{array}$ & $\begin{array}{l}n_{W T}=2, n_{C 615 A}= \\
2, d f=8\end{array}$ & $\begin{array}{l}\text { Contrast test in } \\
\text { linear model }\end{array}$ & 0.02 & 0.03 \\
\hline & $\begin{array}{c}\text { LCTD-WT and LCTD- } \\
\text { C615A in A/B }\end{array}$ & $\begin{array}{c}\text { Mean } \\
\text { difference }\end{array}$ & $\begin{array}{l}n_{W T}=2, n_{C 615 A}= \\
2, d f=8\end{array}$ & $\begin{array}{l}\text { Contrast test in } \\
\text { linear model }\end{array}$ & 0.002 & 0.008 \\
\hline & $\begin{array}{c}\text { LCTD-WT and LCTD- } \\
\text { C615A in B/A }\end{array}$ & $\begin{array}{c}\text { Mean } \\
\text { difference }\end{array}$ & $\begin{array}{l}n_{W T}=2, n_{C 615 A}= \\
2, d f=8\end{array}$ & $\begin{array}{l}\text { Contrast test in } \\
\text { linear model }\end{array}$ & 0.006 & 0.01 \\
\hline \multirow{3}{*}{$5 G$} & $\begin{array}{c}\text { HEK293 and LGP2-WT } \\
\text { in MV }\end{array}$ & $\begin{array}{c}\text { Mean } \\
\text { difference }\end{array}$ & $\begin{array}{l}\mathrm{n}_{\text {HEK }}=3, \mathrm{n}_{\text {LGP2-WT }} \\
=3, \mathrm{df}=18\end{array}$ & $\begin{array}{l}\text { Contrast test in } \\
\text { linear model }\end{array}$ & 0.02 & 0.03 \\
\hline & $\begin{array}{l}\text { HEK293 and LGP2- } \\
\text { C615A in MV }\end{array}$ & $\begin{array}{c}\text { Mean } \\
\text { difference }\end{array}$ & $\begin{array}{l}\mathrm{n}_{\text {HEK }}=3, \mathrm{n}_{\text {LGP2- }} \\
\mathrm{C} 615 \mathrm{~A}=3, \mathrm{df}=18\end{array}$ & $\begin{array}{l}\text { Contrast test in } \\
\text { linear model }\end{array}$ & 0.10 & 0.10 \\
\hline & $\begin{array}{c}\text { LGP2-WT and LGP2- } \\
\text { C615A in MV }\end{array}$ & $\begin{array}{c}\text { Mean } \\
\text { difference }\end{array}$ & $\begin{array}{l}\mathrm{n}_{\text {LGP2-WT }}=3, \\
\mathrm{n}_{\mathrm{LGP2}-\mathrm{C} 615 \mathrm{~A}}=3, \mathrm{df}\end{array}$ & $\begin{array}{c}\text { Contrast test in } \\
\text { linear model }\end{array}$ & $4 e-4$ & 0.001 \\
\hline
\end{tabular}




\begin{tabular}{|c|c|c|c|c|c|c|}
\hline & & & $=18$ & & & \\
\hline \multirow{3}{*}{$5 \mathrm{H}$} & $\begin{array}{c}\text { HEK293 and LGP2-WT } \\
\text { in MV }\end{array}$ & $\begin{array}{c}\text { Mean } \\
\text { difference }\end{array}$ & $\begin{array}{l}n_{\text {HEK }}=3, n_{\text {LGP2-WT }} \\
=3, d f=18\end{array}$ & $\begin{array}{l}\text { Contrast test in } \\
\text { linear model }\end{array}$ & 0.01 & 0.02 \\
\hline & $\begin{array}{c}\text { HEK293 and LGP2- } \\
\text { C615A in MV } \\
\end{array}$ & $\begin{array}{c}\text { Mean } \\
\text { difference }\end{array}$ & $\begin{array}{l}\mathrm{n}_{\mathrm{HEK}}=3, \mathrm{n}_{\mathrm{LGP} 2-} \\
\mathrm{C} 615 \mathrm{~A}=3, \mathrm{df}=18\end{array}$ & $\begin{array}{l}\text { Contrast test in } \\
\text { linear model }\end{array}$ & 0.23 & 0.23 \\
\hline & $\begin{array}{l}\text { LGP2-WT and LGP2- } \\
\text { C615A in MV }\end{array}$ & $\begin{array}{c}\text { Mean } \\
\text { difference }\end{array}$ & $\begin{array}{l}n_{\text {LGP2-WT }}=3, \\
n_{\text {LGP2-C615A }}=3, d f \\
=18\end{array}$ & $\begin{array}{l}\text { Contrast test in } \\
\text { linear model }\end{array}$ & $7 e-4$ & 0.002 \\
\hline \multirow{5}{*}{$6 \mathrm{D}$} & mCherry and LGP2 & $\begin{array}{c}\text { Mean } \\
\text { difference }\end{array}$ & $\begin{array}{l}\mathrm{n}_{\mathrm{mCherry}}=3, \mathrm{n}_{\text {LGP2 }} \\
=3, \mathrm{df}=24\end{array}$ & $\begin{array}{l}\text { Contrast test in } \\
\text { linear model }\end{array}$ & 0.92 & 0.95 \\
\hline & mCherry and RIG-I & $\begin{array}{c}\text { Mean } \\
\text { difference }\end{array}$ & $\begin{array}{l}\mathrm{n}_{\text {mCherry }}=3, \mathrm{n}_{\text {RIG-I }} \\
=3, \mathrm{df}=24\end{array}$ & $\begin{array}{c}\text { Contrast test in } \\
\text { linear model }\end{array}$ & 0.21 & 0.31 \\
\hline & mCherry and MDA5 & $\begin{array}{c}\text { Mean } \\
\text { difference }\end{array}$ & $\begin{array}{l}\mathrm{n}_{\text {mCherry }}=3, \mathrm{n}_{\text {MDA5 }} \\
=3, \mathrm{df}=24\end{array}$ & $\begin{array}{l}\text { Contrast test in } \\
\text { linear model }\end{array}$ & 0.23 & 0.31 \\
\hline & $\begin{array}{l}\text { mCherry and RIG-I- } \\
\text { LGP2 }\end{array}$ & $\begin{array}{c}\text { Mean } \\
\text { difference }\end{array}$ & $\begin{array}{l}\mathrm{n}_{\mathrm{mCherry}}=3, \mathrm{n}_{\text {RIG-I- }} \\
\text { LGP2 }=3, \mathrm{df}=24\end{array}$ & $\begin{array}{l}\text { Contrast test in } \\
\text { linear model }\end{array}$ & 0.17 & 0.31 \\
\hline & $\begin{array}{l}\text { mCherry and MDA5- } \\
\text { LGP2 }\end{array}$ & $\begin{array}{c}\text { Mean } \\
\text { difference }\end{array}$ & $\begin{array}{l}\mathrm{n}_{\text {mCherry }}=3, \mathrm{n}_{\text {MDA5- }} \\
\mathrm{LGP2}=3, \mathrm{df}=24\end{array}$ & $\begin{array}{l}\text { Contrast test in } \\
\text { linear model }\end{array}$ & $3 e-4$ & $2 e-3$ \\
\hline \multirow{8}{*}{$6 \mathrm{E}$} & $\begin{array}{c}\text { LGP2-WT and LGP2- } \\
\text { C615A } 5 \text { ng in PACT } 0 \\
\text { ng }\end{array}$ & $\begin{array}{c}\text { Mean } \\
\text { difference }\end{array}$ & $\begin{array}{l}n_{W T}=4, n_{C 615 A}= \\
4, d f=108\end{array}$ & $\begin{array}{l}\text { Contrast test in } \\
\text { linear model }\end{array}$ & 0.35 & 0.35 \\
\hline & $\begin{array}{c}\text { LGP2-WT and LGP2- } \\
\text { C615A } 5 \mathrm{ng} \text { in PACT } \\
100 \mathrm{ng}\end{array}$ & $\begin{array}{c}\text { Mean } \\
\text { difference }\end{array}$ & $\begin{array}{l}n_{W T}=4, n_{C 615 A}= \\
4, d f=108\end{array}$ & $\begin{array}{l}\text { Contrast test in } \\
\text { linear model }\end{array}$ & $1 e-7$ & $2 e-7$ \\
\hline & $\begin{array}{c}\text { LGP2-WT and LGP2- } \\
\text { C615A } 25 \mathrm{ng} \text { in PACT } \\
0 \mathrm{ng}\end{array}$ & $\begin{array}{c}\text { Mean } \\
\text { difference }\end{array}$ & $\begin{array}{l}n_{W T}=4, n_{C 615 A}= \\
4, d f=108\end{array}$ & $\begin{array}{l}\text { Contrast test in } \\
\text { linear model }\end{array}$ & 0.28 & 0.32 \\
\hline & $\begin{array}{l}\text { LGP2-WT and LGP2- } \\
\text { C615A } 25 \mathrm{ng} \text { in PACT } \\
100 \mathrm{ng}\end{array}$ & $\begin{array}{c}\text { Mean } \\
\text { difference }\end{array}$ & $\begin{array}{l}n_{W T}=4, n_{C 615 A}= \\
4, d f=108\end{array}$ & $\begin{array}{l}\text { Contrast test in } \\
\text { linear model }\end{array}$ & $6 e-11$ & $2 e-10$ \\
\hline & $\begin{array}{c}\text { LGP2-WT and LGP2- } \\
\text { C615A } 50 \mathrm{ng} \text { in PACT } \\
0 \mathrm{ng}\end{array}$ & $\begin{array}{c}\text { Mean } \\
\text { difference }\end{array}$ & $\begin{array}{l}n_{W T}=4, n_{C 615 A}= \\
4, d f=108\end{array}$ & $\begin{array}{l}\text { Contrast test in } \\
\text { linear model }\end{array}$ & 0.003 & 0.004 \\
\hline & $\begin{array}{l}\text { LGP2-WT and LGP2- } \\
\text { C615A } 50 \mathrm{ng} \text { in PACT } \\
100 \mathrm{ng}\end{array}$ & $\begin{array}{c}\text { Mean } \\
\text { difference }\end{array}$ & $\begin{array}{l}n_{W T}=4, n_{C 615 A}= \\
4, d f=108\end{array}$ & $\begin{array}{l}\text { Contrast test in } \\
\text { linear model }\end{array}$ & $1 e-10$ & $3 e-10$ \\
\hline & $\begin{array}{c}\text { LGP2-WT and LGP2- } \\
\text { C615A } 100 \mathrm{ng} \text { in PACT } \\
0 \mathrm{ng}\end{array}$ & $\begin{array}{c}\text { Mean } \\
\text { difference }\end{array}$ & $\begin{array}{l}\mathrm{n}_{\mathrm{WT}}=4, \mathrm{n}_{\mathrm{C615 \textrm {A }}}= \\
4, \mathrm{df}=108\end{array}$ & $\begin{array}{l}\text { Contrast test in } \\
\text { linear model }\end{array}$ & $1 e-4$ & $2 e-4$ \\
\hline & $\begin{array}{c}\text { LGP2-WT and LGP2- } \\
\text { C615A } 100 \mathrm{ng} \text { in PACT } \\
100 \mathrm{ng}\end{array}$ & $\begin{array}{c}\text { Mean } \\
\text { difference }\end{array}$ & $\begin{array}{l}n_{W T}=4, n_{C 615 A}= \\
4, d f=108\end{array}$ & $\begin{array}{l}\text { Contrast test in } \\
\text { linear model }\end{array}$ & $1 e-11$ & $8 e-11$ \\
\hline \multirow{2}{*}{ S3A } & Mock and LGP2 in A/B & $\begin{array}{c}\text { Mean } \\
\text { difference }\end{array}$ & $\begin{array}{l}n_{\text {Mock }}=3, n_{\text {LGP2 }}= \\
3, d f=8\end{array}$ & $\begin{array}{l}\text { Contrast test in } \\
\text { linear model }\end{array}$ & 0.10 & 0.19 \\
\hline & Mock and LGP2 in B/A & $\begin{array}{c}\text { Mean } \\
\text { difference }\end{array}$ & $\begin{array}{l}n_{\text {Mock }}=3, n_{\text {LGP2 }}= \\
3, d f=8\end{array}$ & $\begin{array}{l}\text { Contrast test in } \\
\text { linear model }\end{array}$ & 0.71 & 0.71 \\
\hline \multirow{2}{*}{ S3B } & Mock and LGP2 in A/B & $\begin{array}{c}\text { Mean } \\
\text { difference }\end{array}$ & $\begin{array}{l}n_{\text {Mock }}=2, n_{\text {LGP2 }}= \\
2, d f=4\end{array}$ & $\begin{array}{l}\text { Contrast test in } \\
\text { linear model }\end{array}$ & 0.004 & 0.004 \\
\hline & Mock and LGP2 in B/A & $\begin{array}{c}\text { Mean } \\
\text { difference }\end{array}$ & $\begin{array}{l}n_{\text {Mock }}=2, n_{\text {LGP2 }}= \\
2, d f=4\end{array}$ & $\begin{array}{l}\text { Contrast test in } \\
\text { linear model }\end{array}$ & $9 e-4$ & $2 e-3$ \\
\hline \multirow{3}{*}{$\begin{array}{l}\text { S4A, } \\
\text { top }\end{array}$} & $\begin{array}{c}\text { LGP2-WT and LGP2- } \\
\text { mut in GL2/GL1 in } \\
\text { PACT }\end{array}$ & $\begin{array}{c}\text { Mean } \\
\text { difference }\end{array}$ & $\begin{array}{l}n_{W T}=3, n_{m u t}=3 \\
d f=24\end{array}$ & $\begin{array}{l}\text { Contrast test in } \\
\text { linear model }\end{array}$ & 0.001 & 0.009 \\
\hline & $\begin{array}{l}\text { LGP2-WT and LGP2- } \\
\text { mut GL2/GL1 in MAVS }\end{array}$ & $\begin{array}{c}\text { Mean } \\
\text { difference }\end{array}$ & $\begin{array}{l}n_{W T}=3, n_{m u t}=3 \\
d f=24\end{array}$ & $\begin{array}{l}\text { Contrast test in } \\
\text { linear model }\end{array}$ & 0.09 & 0.22 \\
\hline & $\begin{array}{c}\text { LGP2-WT and LGP2- } \\
\text { mut GL2/GL1 in } \\
\text { RSAD2 }\end{array}$ & $\begin{array}{c}\text { Mean } \\
\text { difference }\end{array}$ & $\begin{array}{l}n_{W T}=3, n_{m u t}=3 \\
d f=24\end{array}$ & $\begin{array}{l}\text { Contrast test in } \\
\text { linear model }\end{array}$ & 0.14 & 0.22 \\
\hline
\end{tabular}




\begin{tabular}{|c|c|c|c|c|c|c|}
\hline & $\begin{array}{l}\text { LGP2-WT and LGP2- } \\
\text { mut GL2/GL1 in OAS2 }\end{array}$ & $\begin{array}{c}\text { Mean } \\
\text { difference }\end{array}$ & $\begin{array}{l}\mathrm{n}_{\mathrm{WT}}=3, \mathrm{n}_{\mathrm{mut}}=3, \\
\mathrm{df}=24\end{array}$ & $\begin{array}{l}\text { Contrast test in } \\
\text { linear model }\end{array}$ & 0.65 & 0.65 \\
\hline & $\begin{array}{l}\text { LGP2-WT and LGP2- } \\
\text { mut GL2/GL1 in RBM4 }\end{array}$ & $\begin{array}{c}\text { Mean } \\
\text { difference }\end{array}$ & $\begin{array}{l}n_{W T}=3, n_{\text {mut }}=3 \\
d f=24\end{array}$ & $\begin{array}{l}\text { Contrast test in } \\
\text { linear model }\end{array}$ & 0.20 & 0.24 \\
\hline & $\begin{array}{l}\text { LGP2-WT and LGP2- } \\
\text { mut GL2/GL1 in SRRT }\end{array}$ & $\begin{array}{c}\text { Mean } \\
\text { difference }\end{array}$ & $\begin{array}{l}\mathrm{n}_{\mathrm{WT}}=3, \mathrm{n}_{\mathrm{mut}}=3 \\
\mathrm{df}=24\end{array}$ & $\begin{array}{l}\text { Contrast test in } \\
\text { linear model }\end{array}$ & 0.15 & 0.22 \\
\hline \multirow{6}{*}{$\begin{array}{l}\text { S4A, } \\
\text { bottom }\end{array}$} & $\begin{array}{c}\text { LGP2-WT and LGP2- } \\
\text { mut in GL1/GL2 in } \\
\text { PACT }\end{array}$ & $\begin{array}{c}\text { Mean } \\
\text { difference }\end{array}$ & $\begin{array}{l}\mathrm{n}_{\mathrm{WT}}=3, \mathrm{n}_{\mathrm{mut}}=3, \\
\mathrm{df}=24\end{array}$ & $\begin{array}{l}\text { Contrast test in } \\
\text { linear model }\end{array}$ & 0.01 & 0.06 \\
\hline & $\begin{array}{l}\text { LGP2-WT and LGP2- } \\
\text { mut GL1/GL2 in MAVS }\end{array}$ & $\begin{array}{c}\text { Mean } \\
\text { difference }\end{array}$ & $\begin{array}{l}n_{W T}=3, n_{m u t}=3 \\
d f=24\end{array}$ & $\begin{array}{l}\text { Contrast test in } \\
\text { linear model }\end{array}$ & 0.48 & 0.73 \\
\hline & $\begin{array}{c}\text { LGP2-WT and LGP2- } \\
\text { mut GL1/GL2 in } \\
\text { RSAD2 }\end{array}$ & $\begin{array}{c}\text { Mean } \\
\text { difference }\end{array}$ & $\begin{array}{l}\mathrm{n}_{\mathrm{WT}}=3, \mathrm{n}_{\mathrm{mut}}=3 \\
\mathrm{df}=24\end{array}$ & $\begin{array}{l}\text { Contrast test in } \\
\text { linear model }\end{array}$ & 0.93 & 0.93 \\
\hline & $\begin{array}{l}\text { LGP2-WT and LGP2- } \\
\text { mut GL1/GL2 in OAS2 }\end{array}$ & $\begin{array}{c}\text { Mean } \\
\text { difference }\end{array}$ & $\begin{array}{l}\mathrm{n}_{\mathrm{WT}}=3, \mathrm{n}_{\mathrm{mut}}=3 \\
\mathrm{df}=24\end{array}$ & $\begin{array}{l}\text { Contrast test in } \\
\text { linear model }\end{array}$ & 0.68 & 0.82 \\
\hline & $\begin{array}{l}\text { LGP2-WT and LGP2- } \\
\text { mut GL1/GL2 in RBM4 }\end{array}$ & $\begin{array}{c}\text { Mean } \\
\text { difference }\end{array}$ & $\begin{array}{l}\mathrm{n}_{\mathrm{WT}}=3, \mathrm{n}_{\mathrm{mut}}=3 \\
\mathrm{df}=24\end{array}$ & $\begin{array}{l}\text { Contrast test in } \\
\text { linear model }\end{array}$ & 0.25 & 0.59 \\
\hline & $\begin{array}{l}\text { LGP2-WT and LGP2- } \\
\text { mut GL1/GL2 in SRRT }\end{array}$ & $\begin{array}{c}\text { Mean } \\
\text { difference }\end{array}$ & $\begin{array}{l}\mathrm{n}_{\mathrm{WT}}=3, \mathrm{n}_{\mathrm{mut}}=3 \\
\mathrm{df}=24\end{array}$ & $\begin{array}{l}\text { Contrast test in } \\
\text { linear model }\end{array}$ & 0.29 & 0.59 \\
\hline
\end{tabular}


Table S2. List of direct and indirect LGP2-specific cellular partners identified by MS. Proteins are listed by their Uniprot accession numbers; gene names and protein scores are also shown. (i), (ii), and (iii) Protein scores for the three biological replicates are indicated by (i), (ii), and (iii). Proteins shaded in gray are already known as interactors of LGP2.

\begin{tabular}{|c|c|c|c|c|}
\hline & & & SCORE & \\
\hline & & & eplicates & \\
\hline $\begin{array}{c}\text { Uniprot } \\
\text { Accession }\end{array}$ & Gene name & $\mathbf{i}$ & ii & iii \\
\hline Q96C10 & Probable ATP-dependent RNA helicase DHX58 OS=Homo sapiens GN=DHX58 PE=1 SV=1 - [DHX58_HUMAN] & 5152,9 & 3941,1 & 3940,4 \\
\hline $\mathrm{O} 75534$ & Cold shock domain-containing protein E1 OS=Homo sapiens GN=CSDE1 PE=1 SV=2 - [CSDE1_HUMAN] & 1075,5 & 698,7 & 678,6 \\
\hline Q8NE71 & ATP-binding cassette sub-family F member $1 \mathrm{OS}=$ Homo sapiens GN=ABCF1 PE=1 SV=2 - [ABCF1_HUMAN] & 813,3 & 437,0 & 425,3 \\
\hline P46940 & Ras GTPase-activating-like protein IQGAP1 OS=Homo sapiens GN=IQGAP1 PE=1 SV=1 - [IQGA1_HUMAN] & 608,6 & 381,3 & 407,3 \\
\hline Q9UPY3 & Endoribonuclease Dicer OS=Homo sapiens GN=DICER1 PE=1 SV=3 - [DICER_HUMAN] & 600,3 & 355,7 & 426,3 \\
\hline Q7Z6Z7 & E3 ubiquitin-protein ligase HUWE1 OS=Homo sapiens GN=HUWE1 PE=1 SV=3 - [HUWE1_HUMAN] & 634,1 & 345,2 & 351,3 \\
\hline O14654 & Insulin receptor substrate 4 OS=Homo sapiens GN=IRS4 PE=1 SV=1 - [IRS4_HUMAN] & 532,9 & 366,8 & 359,3 \\
\hline Q9H6S0 & Probable ATP-dependent RNA helicase YTHDC2 OS=Homo sapiens GN=YTHDC2 PE=1 SV=2 - [YTDC2_HUMAN] & 436,9 & 266,8 & 344,3 \\
\hline $\mathrm{O} 75643$ & $\begin{array}{l}\text { U5 small nuclear ribonucleoprotein } 200 \mathrm{kDa} \text { helicase OS=Homo sapiens } \mathrm{GN}=\mathrm{SNRNP200} \mathrm{PE}=1 \mathrm{SV}=2 \text { - } \\
\text { [U520_HUMAN] }\end{array}$ & 480,5 & 191,3 & 352,9 \\
\hline Q00341 & Vigilin OS=Homo sapiens GN=HDLBP PE=1 SV=2 - [VIGLN_HUMAN] & 478,5 & 274,9 & 199,8 \\
\hline Q7L2E3 & Putative ATP-dependent RNA helicase DHX30 OS=Homo sapiens GN=DHX30 PE $=1$ SV=1 - [DHX30_HUMAN] & 314,9 & 341,3 & 280,1 \\
\hline P26196 & Probable ATP-dependent RNA helicase DDX6 OS=Homo sapiens GN=DDX6 PE=1 SV=2 - [DDX6_HUMAN] & 478,7 & 276,5 & 169,0 \\
\hline Q15020 & $\begin{array}{l}\text { Squamous cell carcinoma antigen recognized by T-cells } 3 \mathrm{OS}=\text { Homo sapiens GN=SART3 PE=1 SV=1 - } \\
\text { [SART3_HUMAN] }\end{array}$ & 391,5 & 270,9 & 256,2 \\
\hline Q9BQG0 & Myb-binding protein 1A OS=Homo sapiens GN=MYBBP1A PE=1 SV=2 - [MBB1A_HUMAN] & 494,5 & 146,0 & 259,3 \\
\hline Q7Z2W4 & Zinc finger CCCH-type antiviral protein $1 \mathrm{OS}=$ Homo sapiens GN=ZC3HAV1 PE=1 SV=3 - [ZCCHV_HUMAN] & 350,2 & 292,4 & 200,7 \\
\hline Q9UQ35 & Serine/arginine repetitive matrix protein 2 OS=Homo sapiens GN=SRRM2 PE=1 SV=2 - [SRRM2_HUMAN] & 383,3 & 233,1 & 219,6 \\
\hline P27816 & Microtubule-associated protein 4 OS=Homo sapiens GN=MAP4 PE=1 SV=3 - [MAP4_HUMAN] & 379,7 & 204,6 & 234,3 \\
\hline Q9H0D6 & 5'-3' exoribonuclease $2 \mathrm{OS}=$ Homo sapiens $\mathrm{GN}=\mathrm{XRN} 2 \mathrm{PE}=1 \mathrm{SV}=1-$ [XRN2_HUMAN] & 482,6 & 183,4 & 142,0 \\
\hline Q6P2Q9 & Pre-mRNA-processing-splicing factor $8 \mathrm{OS}=$ Homo sapiens GN=PRPF8 PE=1 SV=2 - [PRP8_HUMAN] & 364,1 & 184,6 & 242,2 \\
\hline P21796 & $\begin{array}{l}\text { Voltage-dependent anion-selective channel protein } 1 \mathrm{OS}=\text { Homo sapiens } \mathrm{GN}=\mathrm{VDAC1} \mathrm{PE}=1 \mathrm{SV}=2 \text { - } \\
\text { [VDAC1_HUMAN] }\end{array}$ & 392,7 & 207,2 & 143,5 \\
\hline $\mathrm{Q} 00610$ & Clathrin heavy chain $1 \mathrm{OS}=$ Homo sapiens GN=CLTC PE=1 SV=5 - [CLH1_HUMAN] & 293,0 & 229,6 & 220,2 \\
\hline O95071 & E3 ubiquitin-protein ligase UBR5 OS=Homo sapiens GN=UBR5 PE=1 SV=2 - [UBR5_HUMAN] & 368,0 & 148,3 & 226,0 \\
\hline $\mathrm{O} 43143$ & $\begin{array}{l}\begin{array}{l}\text { Putative pre-mRNA-splicing factor ATP-dependent RNA helicase DHX15 OS=Homo sapiens GN=DHX15 PE=1 SV=2 } \\
-[\text { DHX15_HUMAN] }\end{array}\end{array}$ & 319,5 & 220,9 & 187,3 \\
\hline Q8N163 & DBIRD complex subunit KIAA1967 OS=Homo sapiens GN=KIAA1967 PE=1 SV=2 - [K1967_HUMAN] & 301,3 & 197,4 & 207,4 \\
\hline O00291 & Huntingtin-interacting protein $1 \mathrm{OS}=$ Homo sapiens GN=HIP1 PE=1 SV=5 - [HIP1_HUMAN] & 288,5 & 217,3 & 162,4 \\
\hline Q2NL82 & Pre-rRNA-processing protein TSR1 homolog OS=Homo sapiens GN=TSR1 PE=1 SV=1 - [TSR1_HUMAN] & 290,8 & 163,2 & 210,0 \\
\hline O95793 & $\begin{array}{l}\text { Double-stranded RNA-binding protein Staufen homolog } 1 \mathrm{OS}=\text { Homo sapiens GN=STAU1 PE=1 SV=2 - } \\
\text { [STAU1_HUMAN] }\end{array}$ & 261,4 & 167,2 & 226,7 \\
\hline P54136 & Arginine--tRNA ligase, cytoplasmic OS=Homo sapiens GN=RARS PE=1 SV=2 - [SYRC_HUMAN] & 339,3 & 122,4 & 189,8 \\
\hline Q9HCE1 & Putative helicase MOV-10 OS=Homo sapiens GN=MOV10 PE=1 SV=2 - [MOV10_HUMAN] & 290,1 & 174,4 & 184,2 \\
\hline Q9NR30 & Nucleolar RNA helicase 2 OS=Homo sapiens GN=DDX21 PE=1 SV=5 - [DDX21_HUMAN] & 227,7 & 125,9 & 286,4 \\
\hline Q15029 & $\begin{array}{l}116 \mathrm{kDa} \text { U5 small nuclear ribonucleoprotein component OS=Homo sapiens GN=EFTUD2 PE=1 SV=1 - } \\
\text { [U5S1_HUMAN] }\end{array}$ & 308,3 & 125,9 & 196,8 \\
\hline Q9H2U1 & Probable ATP-dependent RNA helicase DHX36 OS=Homo sapiens GN=DHX36 PE=1 SV=2 - [DHX36_HUMAN] & 275,0 & 151,1 & 183,5 \\
\hline Q9Y265 & RuvB-like 1 OS=Homo sapiens GN=RUVBL1 PE=1 SV=1 - [RUVB1_HUMAN] & 358,6 & 113,4 & 133,8 \\
\hline Q5T4S7 & E3 ubiquitin-protein ligase UBR4 OS=Homo sapiens GN=UBR4 PE=1 SV=1 - [UBR4_HUMAN] & 260,9 & 166,0 & 174,6 \\
\hline P56192 & Methionine--tRNA ligase, cytoplasmic OS=Homo sapiens GN=MARS PE=1 SV=2 - [SYMC_HUMAN] & 299,9 & 91,4 & 185,7 \\
\hline Q9H814 & Phosphorylated adapter RNA export protein OS=Homo sapiens GN=PHAX PE=1 SV=1 - [PHAX_HUMAN] & 277,1 & 160,0 & 139,2 \\
\hline Q13895 & Bystin OS=Homo sapiens GN=BYSL PE=1 SV=3 - [BYST_HUMAN] & 280,5 & 118,6 & 172,3 \\
\hline Q86UP2 & Kinectin OS=Homo sapiens GN=KTN1 PE=1 SV=1 - [KTN1_HUMAN] & 158,1 & 179,3 & 232,8 \\
\hline Q8TEQ6 & Gem-associated protein $5 \mathrm{OS}=$ Homo sapiens GN=GEMIN5 PE=1 SV=3 - [GEMI5_HUMAN] & 248,4 & 127,8 & 187,9 \\
\hline Q14152 & Eukaryotic translation initiation factor 3 subunit A OS=Homo sapiens GN=EIF3A PE $=1 \mathrm{SV}=1$ - [EIF3A_HUMAN] & 307,3 & 176,9 & 75,5 \\
\hline P46087 & Putative ribosomal RNA methyltransferase NOP2 OS=Homo sapiens GN=NOP2 PE=1 SV=2 - [NOP2_HUMAN] & 232,4 & 150,9 & 170,7 \\
\hline P46379 & Large proline-rich protein BAG6 OS=Homo sapiens GN=BAG6 PE=1 SV=2 - [BAG6_HUMAN] & 226,4 & 121,6 & 195,5 \\
\hline P17987 & T-complex protein 1 subunit alpha OS=Homo sapiens GN=TCP1 PE=1 SV=1 - [TCPA_HUMAN] & 301,4 & 89,6 & 139,1 \\
\hline Q99714 & 3-hydroxyacyl-CoA dehydrogenase type-2 OS=Homo sapiens GN=HSD17B10 PE=1 SV=3 - [HCD2_HUMAN] & 269,0 & 83,9 & 169,7 \\
\hline Q9NVI7 & $\begin{array}{l}\text { ATPase family AAA domain-containing protein 3A OS=Homo sapiens } \mathrm{GN}=\mathrm{ATAD} 3 \mathrm{~A} \mathrm{PE}=1 \mathrm{SV}=2 \text { - } \\
\text { [ATD3A_HUMAN] }\end{array}$ & 241,1 & 133,7 & 144,5 \\
\hline Q96SB4 & SRSF protein kinase $1 \mathrm{OS}=$ Homo sapiens GN=SRPK1 PE=1 SV=2 - [SRPK1_HUMAN] & 242,9 & 145,8 & 127,0 \\
\hline Q9Y230 & RuvB-like 2 OS=Homo sapiens GN=RUVBL2 PE=1 SV=3 - [RUVB2_HUMAN] & 165,3 & 121,5 & 226,0 \\
\hline P42167 & $\begin{array}{l}\text { Lamina-associated polypeptide 2, isoforms beta/gamma OS=Homo sapiens GN=TMP } \\
\text { [LAP2B_HUMAN] }\end{array}$ & 228,3 & 141,4 & 138,1 \\
\hline $\mathrm{P} 42285$ & Superkiller viralicidic activity 2 -like $2 \mathrm{OS}=$ Homo sapiens GN=SKIV2L2 PE=1 SV=3 - [SK2L2_HUMAN] & 190,8 & 176,1 & 139,9 \\
\hline O43390 & Heterogeneous nuclear ribonucleoprotein $\mathrm{R}$ OS=Homo sapiens $\mathrm{GN}=\mathrm{HNRNPR} \mathrm{PE}=1 \mathrm{SV}=1-$ [HNRPR_HUMAN] & 195,4 & 136,1 & 174,7 \\
\hline Q92499 & ATP-dependent RNA helicase DDX1 OS=Homo sapiens GN=DDX1 PE=1 SV=2 - [DDX1_HUMAN] & 213,4 & 145,6 & 145,5 \\
\hline
\end{tabular}




\begin{tabular}{|c|c|c|c|c|}
\hline Q13243 & Serine/arginine-rich splicing factor 5 OS=Homo sapiens GN=SRSF5 PE=1 SV=1 - [SRSF5_HUMAN] & 193,0 & 148,9 & 154,1 \\
\hline Q12849 & G-rich sequence factor $1 \mathrm{OS}=$ Homo sapiens GN=GRSF1 PE=1 SV=3 - [GRSF1_HUMAN] & 241,3 & 115,9 & 122,3 \\
\hline Q99848 & Probable rRNA-processing protein EBP2 OS=Homo sapiens GN=EBNA1BP2 PE=1 SV=2 - [EBP2_HUMAN] & 186,6 & 130,3 & 160,5 \\
\hline Q13451 & Peptidyl-prolyl cis-trans isomerase FKBP5 OS=Homo sapiens GN=FKBP5 PE=1 SV=2 - [FKBP5_HUMAN] & 214,8 & 107,0 & 153,2 \\
\hline Q13033 & Striatin-3 OS=Homo sapiens GN=STRN3 PE=1 SV=3 - [STRN3_HUMAN] & 212,9 & 152,4 & 109,2 \\
\hline P07910 & Heterogeneous nuclear ribonucleoproteins $\mathrm{C} 1 / \mathrm{C} 2 \mathrm{OS}=\mathrm{Homo}$ sapiens $\mathrm{GN}=\mathrm{HNRNPC}$ PE=1 SV=4 - [HNRPC_HUMAN] & 215,4 & 102,8 & 151,0 \\
\hline P35269 & General transcription factor IIF subunit 1 OS=Homo sapiens GN=GTF2F1 PE=1 SV=2 - [T2FA_HUMAN] & 267,3 & 81,6 & 120,3 \\
\hline O15226 & NF-kappa-B-repressing factor OS=Homo sapiens $\mathrm{GN}=\mathrm{NKRF} \mathrm{PE}=1 \mathrm{SV}=2-\left[\mathrm{NKRF} \_\mathrm{HUMAN}\right]$ & 238,6 & 78,9 & 150,9 \\
\hline $\mathrm{P} 41252$ & Isoleucine--tRNA ligase, cytoplasmic OS=Homo sapiens GN=IARS PE=1 SV=2 - [SYIC_HUMAN] & 229,6 & 108,0 & 124,2 \\
\hline Q9NW13 & RNA-binding protein $28 \mathrm{OS}=\mathrm{Homo}$ sapiens GN=RBM28 PE=1 SV=3 - [RBM28_HUMAN] & 195,1 & 91,7 & 173,3 \\
\hline Q93008 & $\begin{array}{l}\text { Probable ubiquitin carboxyl-terminal hydrolase FAF-X OS=Homo sapiens GN=USP9X PE=1 SV=3 - } \\
\text { [USP9X_HUMAN] }\end{array}$ & 182,0 & 155,0 & 118,1 \\
\hline Q9Y3T6 & $\mathrm{R} 3 \mathrm{H}$ and coiled-coil domain-containing protein $1 \mathrm{OS}=\mathrm{Homo}$ sapiens $\mathrm{GN}=\mathrm{R} 3 \mathrm{HCC} 1 \mathrm{PE}=1 \mathrm{SV}=2-\left[\mathrm{R} 3 \mathrm{HC1} \_\mathrm{HUMAN}\right]$ & 233,7 & 109,0 & 111,4 \\
\hline Q9BQ52 & Zinc phosphodiesterase ELAC protein 2 OS=Homo sapiens GN=ELAC2 PE=1 SV=2 - [RNZ2_HUMAN] & 166,8 & 119,6 & 162,6 \\
\hline Q15751 & Probable E3 ubiquitin-protein ligase HERC1 OS=Homo sapiens GN=HERC1 PE=1 SV=2 - [HERC1_HUMAN] & 215,7 & 87,8 & 137,2 \\
\hline Q5SW79 & Centrosomal protein of $170 \mathrm{kDa}$ OS=Homo sapiens $\mathrm{GN}=\mathrm{CEP} 170 \mathrm{PE}=1 \mathrm{SV}=1-$ [CE170_HUMAN] & 228,8 & 116,7 & 91,4 \\
\hline P42166 & Lamina-associated polypeptide 2 , isoform alpha OS=Homo sapiens GN=TMPO PE $=1 \mathrm{SV}=2$ - [LAP2A_HUMAN] & 187,5 & 130,5 & 118,1 \\
\hline Q9H6T3 & RNA polymerase II-associated protein $3 \mathrm{OS}=$ Homo sapiens $\mathrm{GN}=\mathrm{RPAP} 3 \mathrm{PE}=1 \mathrm{SV}=2-$ [RPAP3_HUMAN] & 242,1 & 90,3 & 100,7 \\
\hline P29692 & Elongation factor 1-delta OS=Homo sapiens GN=EEF1D PE=1 SV=5 - [EF1D_HUMAN] & 184,2 & 139,6 & 107,4 \\
\hline P09661 & U2 small nuclear ribonucleoprotein A' OS=Homo sapiens GN=SNRPA1 PE=1 SV=2 - [RU2A_HUMAN] & 201,1 & 102,5 & 126,5 \\
\hline Q9Y295 & Developmentally-regulated GTP-binding protein $1 \mathrm{OS}=$ Homo sapiens GN=DRG1 PE=1 SV=1 - [DRG1_HUMAN] & 227,0 & 101,7 & 101,2 \\
\hline P50991 & T-complex protein 1 subunit delta OS=Homo sapiens GN=CCT4 PE=1 SV=4 - [TCPD_HUMAN] & 222,1 & 111,4 & 94,5 \\
\hline Q07157 & Tight junction protein ZO-1 OS=Homo sapiens GN=TJP1 PE=1 SV=3 - [ZO1_HUMAN] & 240,5 & 98,8 & 83,7 \\
\hline Q8IY81 & pre-rRNA processing protein FTSJ3 OS=Homo sapiens GN=FTSJ3 PE=1 SV=2 - [RRMJ3_HUMAN] & 171,9 & 156,5 & 93,5 \\
\hline P51114 & Fragile X mental retardation syndrome-related protein $1 \mathrm{OS}=$ Homo sapiens GN=FXR1 PE=1 SV=3 - [FXR1_HUMAN] & 174,7 & 137,0 & 108,8 \\
\hline Q9UJZ1 & Stomatin-like protein $2 \mathrm{OS}=$ Homo sapiens GN=STOML2 PE=1 SV=1 - [STML2_HUMAN] & 194,2 & 139,7 & 84,4 \\
\hline Q15717 & ELAV-like protein 1 OS=Homo sapiens GN=ELAVL1 PE=1 SV=2 - [ELAV1_HUMAN] & 190,0 & 116,1 & 111,8 \\
\hline Q8IZH2 & 5'-3' exoribonuclease $1 \mathrm{OS}=$ Homo sapiens $\mathrm{GN}=\mathrm{XRN} 1 \mathrm{PE}=1 \mathrm{SV}=1$ - [XRN1_HUMAN] & 207,3 & 58,2 & 149,6 \\
\hline Q02952 & A-kinase anchor protein $12 \mathrm{OS}=$ Homo sapiens $\mathrm{GN}=\mathrm{AKAP} 12 \mathrm{PE}=1 \mathrm{SV}=4-$ [AKA12_HUMAN] & 236,7 & 91,0 & 86,3 \\
\hline Q6P158 & Putative ATP-dependent RNA helicase DHX57 OS=Homo sapiens GN=DHX57 PE=1 SV=2 - [DHX57_HUMAN] & 228,7 & 91,2 & 91,4 \\
\hline Q96TA2 & ATP-dependent zinc metalloprotease YME1L1 OS=Homo sapiens GN=YME1L1 PE=1 SV=2 - [YMEL1_HUMAN] & 183,4 & 109,1 & 118,0 \\
\hline Q13325 & $\begin{array}{l}\text { Interferon-induced protein with tetratricopeptide repeats } 5 \mathrm{OS}=\text { Homo sapiens } \mathrm{GN}=\mathrm{IFIT5} \mathrm{PE}=1 \mathrm{SV}=1 \text { - } \\
\text { [IFIT5_HUMAN] }\end{array}$ & 205,9 & 92,9 & 110,7 \\
\hline Q86VM9 & Zinc finger $\mathrm{CCCH}$ domain-containing protein $18 \mathrm{OS}=$ Homo sapiens GN=ZC3H18 PE=1 SV=2 - [ZCH18_HUMAN] & 205,1 & 129,2 & 75,0 \\
\hline P08621 & U1 small nuclear ribonucleoprotein $70 \mathrm{kDa}$ OS=Homo sapiens GN=SNRNP70 PE=1 SV=2 - [RU17_HUMAN] & 124,3 & 134,0 & 148,0 \\
\hline P35232 & Prohibitin OS=Homo sapiens GN=PHB PE=1 SV=1 - [PHB_HUMAN] & 265,8 & 61,2 & 78,7 \\
\hline O60884 & DnaJ homolog subfamily A member 2 OS=Homo sapiens GN=DNAJA2 PE=1 SV=1 - [DNJA2_HUMAN] & 150,1 & 127,1 & 124,8 \\
\hline Q9H9B4 & Sideroflexin-1 OS=Homo sapiens GN=SFXN1 PE=1 SV=4 - [SFXN1_HUMAN] & 172,0 & 134,4 & 91,3 \\
\hline Q7Z2T5 & TRMT1-like protein OS=Homo sapiens GN=TRMT1L PE=1 SV=2 - [TRM1L_HUMAN] & 172,0 & 110,8 & 114,1 \\
\hline Q9Y606 & tRNA pseudouridine synthase A, mitochondrial OS=Homo sapiens GN=PUS1 PE=1 SV=3 - [TRUA_HU & 145,1 & 149,2 & 101,1 \\
\hline Q14258 & E3 ubiquitin/ISG15 ligase TRIM25 OS=Homo sapiens GN=TRIM25 PE=1 SV=2 - [TRI25_HUMAN] & 187,8 & 103,3 & 100,9 \\
\hline Q01780 & Exosome component $10 \mathrm{OS}=$ Homo sapiens GN=EXOSC10 PE=1 SV=2 - [EXOSX_HUMAN] & 161,6 & 126,8 & 99,6 \\
\hline P22087 & rRNA 2'-O-methyltransferase fibrillarin OS=Homo sapiens GN=FBL PE=1 SV=2 - [FBRL_HUMAN] & 145,7 & 107,3 & 135,0 \\
\hline Q14318 & Peptidyl-prolyl cis-trans isomerase FKBP8 OS=Homo sapiens GN=FKBP8 PE=1 SV=2 - [FKBP8_HUMAN] & 140,3 & 93,2 & 153,6 \\
\hline Q04637 & Eukaryotic translation initiation factor 4 gamma $1 \mathrm{OS}=$ Homo sapiens GN=EIF4G1 PE=1 SV=4 - [IF4G1_HUMAN] & 199,8 & 64,0 & 121,8 \\
\hline P50402 & Emerin OS=Homo sapiens GN=EMD PE=1 SV=1 - [EMD_HUMAN] & 166,4 & 115,9 & 102,9 \\
\hline Q12797 & Aspartyl/asparaginyl beta-hydroxylase $\mathrm{OS}=$ Homo sapiens $\mathrm{GN}=\mathrm{ASPH} \mathrm{PE}=1$ & 144,3 & 112,4 & 126,2 \\
\hline Q5T9A4 & $\begin{array}{l}\text { ATPase family AAA domain-containing protein 3B OS=Homo sapiens GN=ATAD3B PE=1 SV=1 - } \\
\text { [ATD3B_HUMAN] }\end{array}$ & 127,3 & 113,3 & 140,5 \\
\hline Q99832 & T-complex protein 1 subunit eta $\mathrm{OS}=$ Homo sapiens $\mathrm{GN}=\mathrm{CCT} 7 \mathrm{PE}=1 \mathrm{SV}=2-\left[\mathrm{TCPH} \_\mathrm{HUMAN}\right]$ & 201,1 & 79,6 & 99,7 \\
\hline Q9H3H3 & UPF0696 protein C11orf68 OS=Homo sapiens GN=C11orf68 PE=1 SV=2 - [CK068_HUMAN] & 172,9 & 87,7 & 119,7 \\
\hline P10155 & $60 \mathrm{kDa}$ SS-A/Ro ribonucleoprotein OS=Homo sapiens GN=TROVE2 PE=1 SV=2 - [RO60_HUMAN] & 160,9 & 77,8 & 139,7 \\
\hline P30876 & DNA-directed RNA polymerase II subunit RPB2 OS=Homo sapiens GN=POLR2B PE=1 SV=1 - [RPB2_HUn & 121,8 & 114,3 & 137,7 \\
\hline Q86UE4 & Protein LYRIC OS=Homo sapiens GN=MTDH PE=1 SV=2 - [LYRIC_HUMAN] & 134,6 & 123,3 & 113,0 \\
\hline Q9P035 & $\begin{array}{l}\text { Very-long-chain (3R)-3-hydroxyacyl-[acyl-carrier protein] dehydratase } 3 \text { OS=Homo sapiens GN=PTPLAD1 PE=1 } \\
\text { SV=2 - [HACD3_HUMAN] }\end{array}$ & 173,7 & 84,6 & 110,8 \\
\hline Q5RKV6 & Exosome complex component MTR3 OS=Homo sapiens GN=EXOSC6 PE=1 SV=1 - [EXOS6_HUMAN] & 192,1 & 84,1 & 92,4 \\
\hline Q641Q2 & WASH complex subunit FAM21A OS=Homo sapiens GN=FAM21A PE=1 SV=3 - [FA21A_HUMAN] & 161,5 & 77,8 & 126,6 \\
\hline P40939 & Trifunctional enzyme subunit alpha, mitochondrial OS=Homo sapiens GN=HADHA PE=1 SV=2 - [ECHA_H & 226,7 & 62,6 & 76,1 \\
\hline O00139 & Kinesin-like protein KIF2A OS=Homo sapiens GN=KIF2A PE $=1 \mathrm{SV}=3$ - [KIF2A_HUMAN] & 151,1 & 64,5 & 145,2 \\
\hline Q13610 & Periodic tryptophan protein 1 homolog OS=Homo sapiens GN=PWP1 PE=1 SV=1 - [PWP1_HUMAN] & 178,8 & 71,1 & 108,2 \\
\hline Q92900 & Regulator of nonsense transcripts 1 OS=Homo sapiens GN=UPF1 PE=1 SV=2 - [RENT1_HUMAN] & 127,6 & 69,4 & 160,5 \\
\hline Q9UNF1 & Melanoma-associated antigen D2 OS=Homo sapiens GN=MAGED2 PE=1 SV=2 - [MAGD2_HUMAN] & 196,3 & 98,1 & 62,8 \\
\hline O95347 & Structural maintenance of chromosomes protein $2 \mathrm{OS}=$ Homo sapiens $\mathrm{GN}=\mathrm{SMC} 2 \mathrm{PE}=1 \mathrm{SV}=2-\left[\mathrm{SMC} 2 \_\mathrm{HUMAN}\right.$ ] & 161,8 & 77,7 & 116,2 \\
\hline Q99459 & Cell division cycle 5-like protein OS=Homo sapiens GN=CDC5L PE=1 SV=2 - [CDC5L_HUMAN] & 149,8 & 123,1 & 81,2 \\
\hline P51116 & Fragile X mental retardation syndrome-related protein $2 \mathrm{OS}=$ Homo sapiens GN=FXR2 PE=1 SV=2 - [FXR2_HUMAN] & 169,1 & 93,3 & 88,2 \\
\hline Q08J23 & tRNA (cytosine(34)-C(5))-methyltransferase OS=Homo sapiens GN=NSUN2 PE=1 SV=2 - [NSUN2_HUMAN] & 203,7 & 41,6 & 101,3 \\
\hline P52732 & Kinesin-like protein KIF11 OS=Homo sapiens GN=KIF11 PE=1 SV=2 - [KIF11_HUMAN] & 193,5 & 105,1 & 46,1 \\
\hline
\end{tabular}




\begin{tabular}{|c|c|c|c|c|}
\hline O00165 & HCLS1-associated protein X-1 OS=Homo sapiens GN=HAX1 PE=1 SV=2 - [HAX1_HUMAN] & 120,2 & 94,3 & 128,6 \\
\hline $\mathrm{P} 60228$ & Eukaryotic translation initiation factor 3 subunit $\mathrm{E}$ OS=Homo sapiens GN=EIF3E PE $=1 \mathrm{SV}=1-$ [EIF3E_HUMAN] & 191,8 & 65,2 & 83,8 \\
\hline Q09161 & Nuclear cap-binding protein subunit $1 \mathrm{OS}=$ Homo sapiens GN=NCBP1 PE=1 SV=1 - [NCBP1_HUMAN] & 134,3 & 121,1 & 83,5 \\
\hline Q9BYG3 & $\begin{array}{l}\text { MKI67 FHA domain-interacting nucleolar phosphoprotein OS=Homo sapiens GN=MKI67IP PE=1 SV=1 - } \\
\text { [MK67I_HUMAN] }\end{array}$ & 157,9 & 71,7 & 107,6 \\
\hline O60762 & Dolichol-phosphate mannosyltransferase OS=Homo sapiens GN=DPM1 PE=1 SV=1 - [DPM1_HUMAN] & 96,0 & 132,4 & 108,3 \\
\hline Q96A33 & Coiled-coil domain-containing protein 47 OS=Homo sapiens GN=CCDC47 PE=1 SV=1 - [CCD47_HUMAN] & 159,3 & 105,8 & 68,4 \\
\hline Q9NQT5 & Exosome complex component RRP40 OS=Homo sapiens GN=EXOSC3 PE=1 SV=3 - [EXOS3_HUMAN] & 149,9 & 108,6 & 74,1 \\
\hline P62244 & 40S ribosomal protein S15a OS=Homo sapiens GN=RPS15A PE=1 SV=2 - [RS15A_HUMAN] & 110,2 & 85,7 & 134,1 \\
\hline Q8NCA5 & Protein FAM98A OS=Homo sapiens GN=FAM98A PE $=1 \mathrm{SV}=1-$ [FA98A_HUMAN] & 211,5 & 43,1 & 73,5 \\
\hline O95822 & Malonyl-CoA decarboxylase, mitochondrial OS=Homo sapiens GN=MLYCD PE=1 SV=3 - [DCMC_HUMAN] & 163,5 & 86,5 & 78,1 \\
\hline Q06787 & Fragile $\mathrm{X}$ mental retardation protein $1 \mathrm{OS}=$ Homo sapiens GN=FMR1 PE=1 SV=1 - [FMR1_HUMAN] & 131,5 & 69,9 & 126,1 \\
\hline Q15056 & Eukaryotic translation initiation factor 4H OS=Homo sapiens GN=EIF4H PE=1 SV=5 - [IF4H_HUMAN] & 126,4 & 103,6 & 97,5 \\
\hline Q9Y3D9 & 28S ribosomal protein $\mathrm{S} 23$, mitochondrial $\mathrm{OS}=$ Homo sapiens $\mathrm{GN}=\mathrm{MRPS} 23 \mathrm{PE}=1 \mathrm{SV}=2-$ [RT23_HUMAN] & 146,2 & 90,0 & 90,2 \\
\hline 060231 & $\begin{array}{l}\begin{array}{l}\text { Putative pre-mRNA-splicing factor ATP-dependent RNA helicase DHX16 OS=Homo sapiens GN=DHX16 PE=1 SV=2 } \\
-[\text { DHX16_HUMAN] }\end{array}\end{array}$ & 94,7 & 120,2 & 111,1 \\
\hline Q08170 & Serine/arginine-rich splicing factor 4 OS=Homo sapiens GN=SRSF4 PE=1 SV=2 - [SRSF4_HUMAN] & 139,1 & 91,1 & 92,6 \\
\hline Q8IYB3 & Serine/arginine repetitive matrix protein $1 \mathrm{OS}=$ Homo sapiens GN=SRRM1 PE=1 SV=2 - [SRRM1_HUMAN] & 147,6 & 75,3 & 98,9 \\
\hline Q92552 & 28S ribosomal protein S27, mitochondrial OS=Homo sapiens GN=MRPS27 PE=1 SV=3 - [RT27_HUMAN] & 145,3 & 51,4 & 125,2 \\
\hline P78347 & General transcription factor II-I OS=Homo sapiens GN=GTF2I PE $=1 \mathrm{SV}=2$ - [GTF2I_HUMAN] & 173,4 & 77,1 & 69,5 \\
\hline Q9NS69 & $\begin{array}{l}\begin{array}{l}\text { Mitochondrial import receptor subunit TOM22 homolog OS=Homo sapiens GN=TOMM22 PE=1 SV=3 - } \\
\text { [TOM22_HUMAN] }\end{array} \\
\end{array}$ & 169,0 & 103,7 & 46,0 \\
\hline Q9NZB2 & $\begin{array}{l}\text { Constitutive coactivator of PPAR-gamma-like protein } 1 \mathrm{OS}=\text { Homo sapiens GN=FAM120A PE=1 SV=2 - } \\
\text { [F120A_HUMAN] }\end{array}$ & 131,4 & 93,1 & 92,7 \\
\hline Q9Y5A9 & YTH domain family protein $2 \mathrm{OS}=$ Homo sapiens GN=YTHDF2 PE=1 SV=2 - [YTHD2_HUMAN] & 94,0 & 125,3 & 97,5 \\
\hline Q92665 & 28S ribosomal protein S31, mitochondrial OS=Homo sapiens GN=MRPS31 PE=1 SV=3 - [RT31_HUMAN] & 142,5 & 63,1 & 111,0 \\
\hline P18615 & Negative elongation factor $\mathrm{E}$ OS=Homo sapiens GN=RDBP PE $=1 \mathrm{SV}=3$ - [NELFE_HUMAN] & 173,2 & 51,8 & 91,2 \\
\hline Q31612 & $\begin{array}{l}\text { HLA class I histocompatibility antigen, B-73 alpha chain OS=Homo sapiens GN=HLA-B PE=1 SV=1 - } \\
\text { [1B73_HUMAN] }\end{array}$ & 131,0 & 103,0 & 81,3 \\
\hline Q13868 & Exosome complex component RRP4 OS=Homo sapiens GN=EXOSC2 PE=1 SV=2 - [EXOS2_HUMAN] & 120,7 & 77,9 & 115,5 \\
\hline $\mathrm{P} 42696$ & RNA-binding protein $34 \mathrm{OS}=$ Homo sapiens GN=RBM34 PE=1 SV=2 - [RBM34_HUMAN] & 117,6 & 107,0 & 85,8 \\
\hline Q9BXP5 & Serrate RNA effector molecule homolog OS=Homo sapiens GN=SRRT PE=1 SV=1 - [SRRT_HUMAN] & 171,3 & 84,5 & 50,5 \\
\hline Q13247 & Serine/arginine-rich splicing factor 6 OS=Homo sapiens GN=SRSF6 PE=1 SV=2 - [SRSF6_HUMAN] & 101,5 & 101,1 & 101,3 \\
\hline Q4G0J3 & La-related protein 7 OS=Homo sapiens GN=LARP7 PE=1 SV=1 - [LARP7_HUMAN] & 174,3 & 62,5 & 65,5 \\
\hline P19525 & $\begin{array}{l}\text { Interferon-induced, double-stranded RNA-activated protein kinase OS=Homo sapiens GN=EIF2AK2 PE=1 SV=2 - } \\
\text { [E2AK2_HUMAN] }\end{array}$ & 102,7 & 95,0 & 102,6 \\
\hline Q9Y305 & Acyl-coenzyme A thioesterase 9, mitochondrial OS=Homo sapiens GN=ACOT9 PE=1 SV=2 - [ACOT9_HUMAN] & 119,5 & 80,7 & 99,4 \\
\hline Q16630 & $\begin{array}{l}\text { Cleavage and polyadenylation specificity factor subunit } 6 \text { OS=Homo sapiens GN=CPSF6 PE=1 SV=2 - } \\
\text { [CPSF6_HUMAN] }\end{array}$ & 158,5 & 57,2 & 82,7 \\
\hline Q9GZR7 & ATP-dependent RNA helicase DDX24 OS=Homo sapiens GN=DDX24 PE=1 SV=1 - [DDX24_HUMAN] & 131,7 & 61,7 & 101,3 \\
\hline P26640 & Valine--tRNA ligase OS=Homo sapiens GN=VARS PE=1 SV=4 - [SYVC_HUMAN] & 133,1 & 62,9 & 97,7 \\
\hline Q96QR8 & Transcriptional activator protein Pur-beta OS=Homo sapiens GN=PURB PE=1 SV=3 - [PURB_HUMAN] & 120,4 & 73,9 & 97,4 \\
\hline P38919 & Eukaryotic initiation factor 4A-III OS=Homo sapiens GN=EIF4A3 PE=1 SV=4 - [IF4A3_HUMAN] & 154,3 & 75,9 & 59,5 \\
\hline Q9NQ55 & Suppressor of SWI4 1 homolog OS=Homo sapiens GN=PPAN PE=1 SV=1 - [SSF1_HUMAN] & 150,5 & 60,1 & 78,8 \\
\hline O75396 & Vesicle-trafficking protein SEC22b OS=Homo sapiens GN=SEC22B PE=1 SV=4 - [SC22B_HUMAN] & 121,6 & 93,5 & 73,9 \\
\hline O00178 & GTP-binding protein $1 \mathrm{OS}=$ Homo sapiens GN=GTPBP1 PE=1 SV=3 - [GTPB1_HUMAN] & 156,3 & 66,8 & 64,4 \\
\hline P51398 & $28 \mathrm{~S}$ ribosomal protein $\mathrm{S} 29$, mitochondrial $\mathrm{OS}=$ Homo sapiens $\mathrm{GN}=\mathrm{DAP} 3 \mathrm{PE}=1 \mathrm{SV}=1$ - [RT29_HUMAN] & 109,0 & 54,7 & 120,5 \\
\hline Q13148 & TAR DNA-binding protein 43 OS=Homo sapiens GN=TARDBP PE=1 SV=1 - [TADBP_HUMAN] & 112,5 & 105,9 & 63,9 \\
\hline $\mathrm{P} 48643$ & T-complex protein 1 subunit epsilon $\mathrm{OS}=$ Homo sapiens $\mathrm{GN}=\mathrm{CCT} 5 \mathrm{PE}=1 \mathrm{SV}=1$ - [TCPE_HUMAN] & 111,8 & 93,3 & 76,4 \\
\hline Q9BRJ6 & Uncharacterized protein C7orf50 OS=Homo sapiens GN=C7orf50 PE=1 SV=1 - [CG050_HUMAN] & 110,9 & 84,1 & 85,4 \\
\hline P62851 & 40S ribosomal protein $\mathrm{S} 25 \mathrm{OS}=$ Homo sapiens GN=RPS25 PE=1 SV=1 - [RS25_HUMAN] & 66,1 & 121,3 & 91,9 \\
\hline P12004 & 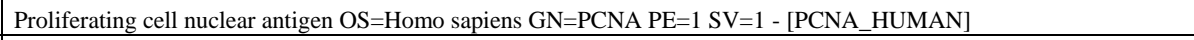 & 120,3 & 84,5 & 73,2 \\
\hline Q9NRL3 & Striatin-4 OS=Homo sapiens GN=STRN4 PE=1 SV=2 - [STRN4_HUMAN] & 56,2 & 109,4 & 111,4 \\
\hline Q14008 & Cytoskeleton-associated protein 5 OS=Homo sapiens GN=CKAP5 PE=1 SV=3 - [CKAP5_HUMAN] & 173,5 & 41,5 & 61,5 \\
\hline Q14683 & Structural maintenance of chromosomes protein $1 \mathrm{~A}$ OS=Homo sapiens $\mathrm{GN}=\mathrm{SMC1A}$ PE $=1 \mathrm{SV}=2-\left[\mathrm{SMC} 1 \mathrm{~A} \_\mathrm{H}\right.$ & 91,1 & 112,4 & 71,8 \\
\hline Q14498 & RNA-binding protein 39 OS=Homo sapiens GN=RBM39 PE=1 SV=2 - [RBM39_HUMAN] & 80,9 & 106,2 & 88,1 \\
\hline A6NHR9 & $\begin{array}{l}\begin{array}{l}\text { Structural maintenance of chromosomes flexible hinge domain-containing protein } 1 \mathrm{OS}=\text { Homo sapiens GN=SMCHD1 } \\
\mathrm{PE}=1 \mathrm{SV}=2 \text { - [SMHD1_HUMAN] }\end{array}\end{array}$ & 152,9 & 44,9 & 77,0 \\
\hline Q52LJ0 & Protein FAM98B OS=Homo sapiens GN=FAM98B PE=1 SV=1 - [FA98B_HUMAN] & 123,2 & 48,5 & 101,2 \\
\hline Q96HS1 & $\begin{array}{l}\text { Serine/threonine-protein phosphatase PGAM5, mitochondrial OS=Homo sapiens GN=PGAM5 PE=1 SV=2 - } \\
\text { [PGAM5_HUMAN] }\end{array}$ & 120,1 & 69,0 & 83,8 \\
\hline O14744 & Protein arginine N-methyltransferase 5 OS=Homo sapiens GN=PRMT5 PE=1 SV=4 - [ANM5_HUMAN] & 123,4 & 83,9 & 64,8 \\
\hline O60832 & H/ACA ribonucleoprotein complex subunit $4 \mathrm{OS}=$ Homo sapiens $\mathrm{GN}=\mathrm{DKC1} \mathrm{PE}=1 \mathrm{SV}=3-$ [DKC1_HUMAN] & 153,5 & 45,7 & 71,7 \\
\hline Q8TDD1 & ATP-dependent RNA helicase DDX54 OS=Homo sapiens GN=DDX54 PE=1 SV=2 - [DDX54_HUMAN] & 115,1 & 85,8 & 69,9 \\
\hline O00411 & DNA-directed RNA polymerase, mitochondrial OS=Homo sapiens GN=POLRMT PE=1 SV=2 - [RPOM_HUMAN] & 111,9 & 117,2 & 41,5 \\
\hline Q6PKG0 & La-related protein $1 \mathrm{OS}=$ Homo sapiens GN=LARP1 PE=1 SV=2 - [LARP1_HUMAN] & 161,1 & 62,3 & 46,3 \\
\hline O43172 & U4/U6 small nuclear ribonucleoprotein Prp4 OS=Homo sapiens GN=PRPF4 PE=1 SV=2 - [PRP4_HUMAN] & 136,8 & 66,7 & 66,0 \\
\hline Q07812 & Apoptosis regulator $\mathrm{BAX} \mathrm{OS}=\mathrm{Homo}$ sapiens $\mathrm{GN}=\mathrm{BAX} \mathrm{PE}=1 \mathrm{SV}=1-$ [BAX_HUMAN] & 158,2 & 66,4 & 44,1 \\
\hline Q32MZ4 & Leucine-rich repeat flightless-interacting protein $1 \mathrm{OS}=$ Homo sapiens GN=LRRFIP1 PE=1 SV=2 - [LRRF1_HUMAN] & 138,9 & 70,5 & 57,2 \\
\hline Q9H5H4 & Zinc finger protein $768 \mathrm{OS}=$ Homo sapiens GN=ZNF768 PE=1 SV=2 - [ZN768_HUMAN] & 116,0 & 82,6 & 66,1 \\
\hline
\end{tabular}




\begin{tabular}{|c|c|c|c|c|}
\hline 615 & DnaJ homolog subfamily C member 7 OS=Homo sapiens GN=DNAJC7 PE=1 SV=2 - [DNJC7_HUMAN] & 117,6 & 70,7 & 75,8 \\
\hline Q53GS9 & U4/U6.U5 tri-snRNP-associated protein 2 OS=Homo sapiens GN=USP39 PE=1 SV=2 - [SNUT2_HUMAN] & 104,6 & 70,2 & 85,4 \\
\hline Q86W50 & Methyltransferase-like protein $16 \mathrm{OS}=$ Homo sapiens GN=METTL16 PE=1 SV=2 - [MET16_HUMAN] & 85,2 & 73,1 & 101,6 \\
\hline Q9BZE4 & Nucleolar GTP-binding protein 1 OS=Homo sapiens GN=GTPBP4 PE=1 SV=3 - [NOG1_HUMAN] & 78,5 & 80,5 & 100,3 \\
\hline Q9Y4W6 & AFG3-like protein $2 \mathrm{OS}=$ Homo sapiens $\mathrm{GN}=\mathrm{AFG} 3 \mathrm{~L} 2 \mathrm{PE}=1 \mathrm{SV}=2-$ [AFG32_HUMAN] & 97,7 & 94,4 & 67,1 \\
\hline Q96SI9 & Spermatid perinuclear RNA-binding protein OS=Homo sapiens GN=STRBP PE=1 SV=1 - [STRBP_HUMAN] & 111,8 & 65,6 & 81,6 \\
\hline $\mathrm{P} 11441$ & Ubiquitin-like protein 4A OS=Homo sapiens GN=UBL4A PE=1 SV=1 - [UBL4A_HUMAN] & 98,8 & 71,6 & 87,7 \\
\hline Q9BWF3 & RNA-binding protein $4 \mathrm{OS}=$ Homo sapiens $\mathrm{GN}=\mathrm{RBM} 4 \mathrm{PE}=1 \mathrm{SV}=1-$ [RBM4_HUMAN] & 84,5 & 90,4 & 77,8 \\
\hline Q15287 & RNA-binding protein with serine-rich domain $1 \mathrm{OS}=$ Homo sapiens GN=RNPS1 PE=1 SV=1 - [RNPS1_HUMAN] & 107,8 & 76,9 & 64,4 \\
\hline O15381 & Nuclear valosin-containing protein-like $\mathrm{OS}=$ Homo sapiens $\mathrm{GN}=\mathrm{NVL} \mathrm{PE}=1 \mathrm{SV}=1$ - [NVL_HUMAN] & 104,2 & 67,2 & 73,6 \\
\hline Q96EY1 & $\begin{array}{l}\text { DnaJ homolog subfamily A member 3, mitochondrial OS=Homo sapiens GN=DNAJA3 PE=1 SV=2 - } \\
\text { [DNJA3_HUMAN] }\end{array}$ & 121,2 & 56,7 & 66,7 \\
\hline Q8WY22 & BRI3-binding protein $\mathrm{OS}=$ Homo sapiens $\mathrm{GN}=\mathrm{BRI} 3 \mathrm{BP} \mathrm{PE}=1 \mathrm{SV}=1-$ [BRI3B_HUMAN] & 123,1 & 66,5 & 54,8 \\
\hline Q5VTE6 & Protein angel homolog $2 \mathrm{OS}=$ Homo sapiens $\mathrm{GN}=\mathrm{ANGEL} 2 \mathrm{PE}=2 \mathrm{SV}=1$ - [ANGE2_HUMAN] & 70,3 & 93,3 & 80,4 \\
\hline P17480 & Nucleolar transcription factor $1 \mathrm{OS}=$ Homo sapiens GN=UBTF PE $=1 \mathrm{SV}=1$ - [UBF1_HUMAN] & 110,6 & 56,1 & 75,9 \\
\hline P62081 & 40S ribosomal protein $\mathrm{S} 7 \mathrm{OS}=$ Homo sapiens $\mathrm{GN}=\mathrm{RPS7} \mathrm{PE}=1 \mathrm{SV}=1-$ [RS7_HUMAN] & 122,1 & 49,1 & 70,1 \\
\hline Q9Y520 & Protein PRRC2C OS=Homo sapiens GN=PRRC2C PE=1 SV=4 - [PRC2C_HUMAN] & 101,8 & 72,6 & 66,6 \\
\hline Q9Y5M8 & Signal recognition particle receptor subunit beta $\mathrm{OS}=$ Homo sapiens $\mathrm{GN}=\mathrm{SRPRB}$ PE $=1 \mathrm{SV}=3-$ [SRPRB_HUMAN] & 98,2 & 77,2 & 65,0 \\
\hline Q9BV44 & THUMP domain-containing protein 3 OS=Homo sapiens GN=THUMPD3 PE=1 SV=1 - [THUM3_HUMAN] & 86,6 & 64,3 & 88,2 \\
\hline Q96KR1 & Zinc finger RNA-binding protein OS=Homo sapiens GN=ZFR PE=1 SV=2 - [ZFR_HUMAN] & 134,1 & 63,1 & 41,5 \\
\hline O43324 & Eukaryotic translation elongation factor 1 epsilon-1 OS=Homo sapiens GN=EEF1E1 PE=1 SV=1 - [MCA3_HUMAN] & 95,6 & 58,5 & 83,5 \\
\hline Q9H0U6 & 39S ribosomal protein L18, mitochondrial OS=Homo sapiens GN=MRPL18 PE=1 SV=1 - [RM18_HUMAN] & 71,8 & 84,5 & 81,1 \\
\hline Q9HCN4 & GPN-loop GTPase 1 OS=Homo sapiens GN=GPN1 PE=1 SV=1 - [GPN1_HUMAN] & 110,2 & 65,6 & 61,1 \\
\hline Q3KQU3 & MAP7 domain-containing protein 1 OS=Homo sapiens GN=MAP7D1 PE=1 SV=1 - [MA7D1_HUMAN] & 89,1 & 68,9 & 75,5 \\
\hline Q9BYN8 & $28 \mathrm{~S}$ ribosomal protein $\mathrm{S} 26$, mitochondrial $\mathrm{OS}=$ Homo sapiens $\mathrm{GN}=\mathrm{MRPS} 26 \mathrm{PE}=1 \mathrm{SV}=1-$ [RT26_HUMAN] & 55,8 & 84,9 & 91,2 \\
\hline Q9NYF8 & Bcl-2-associated transcription factor $1 \mathrm{OS}=$ Homo sapiens GN=BCLAF1 PE=1 SV=2 - [BCLF1_HUMAN] & 92,6 & 76,2 & 62,7 \\
\hline Q66PJ3 & $\begin{array}{l}\text { ADP-ribosylation factor-like protein 6-interacting protein } 4 \mathrm{OS}=\text { Homo sapiens GN=ARL6IP4 PE=1 SV=1 - } \\
\text { [AR6P4_HUMAN] }\end{array}$ & 86,6 & 70,0 & 74,8 \\
\hline Q9UBS4 & DnaJ homolog subfamily B member 11 OS=Homo sapiens GN=DNAJB11 PE=1 SV=1 - [DJB11_HUMAN] & 47,9 & 82,2 & 99,2 \\
\hline Q9Y285 & Phenylalanine--tRNA ligase alpha subunit OS=Homo sapiens GN=FARSA PE $=1 \mathrm{SV}=3$ - [SYFA_HUMAN] & 100,6 & 61,2 & 66,5 \\
\hline Q9H2G4 & Testis-specific Y-encoded-like protein 2 OS=Homo sapiens GN=TSPYL2 PE=1 SV=1 - [TSYL2_HUMAN] & 101,9 & 68,6 & 57,3 \\
\hline O00541 & Pescadillo homolog OS=Homo sapiens GN=PES1 PE=1 SV=1 - [PESC_HUMAN] & 82,0 & 59,8 & 84,7 \\
\hline Q15907 & Ras-related protein Rab-11B OS=Homo sapiens GN=RAB11B PE=1 SV=4 - [RB11B_HUMAN] & 110,2 & 49,2 & 64,7 \\
\hline Q9NQ29 & Putative RNA-binding protein Luc7-like $1 \mathrm{OS}=$ Homo sapiens GN=LUC7L PE $=1 \mathrm{SV}=1-$ [LUC7L_HUMAN] & 91,6 & 82,5 & 50,1 \\
\hline P62910 & 60S ribosomal protein $\mathrm{L} 32 \mathrm{OS}=\mathrm{Homo}$ sapiens $\mathrm{GN}=\mathrm{RPL} 32 \mathrm{PE}=1 \mathrm{SV}=2$ - [RL32_HUMAN] & 91,8 & 62,2 & 69,4 \\
\hline Q6NZY4 & Zinc finger $\mathrm{CCHC}$ domain-containing protein $8 \mathrm{OS}=$ Homo sapiens $\mathrm{GN}=\mathrm{ZCCHC} 8 \mathrm{PE}=1 \mathrm{SV}=2-[\mathrm{Z}$ & 61,1 & 91,5 & 69,5 \\
\hline P15880 & 40S ribosomal protein $\mathrm{S} 2 \mathrm{OS}=\mathrm{Homo}$ sapiens $\mathrm{GN}=\mathrm{RPS} 2 \mathrm{PE}=1 \mathrm{SV}=2-\left[\mathrm{RS} 2 \_\mathrm{HUMAN}\right]$ & 102,6 & 58,7 & 60,2 \\
\hline P62318 & Small nuclear ribonucleoprotein Sm D3 OS=Homo sapiens GN=SNRPD3 PE=1 SV=1 - [SMD3_HUMAN] & 60,9 & 81,2 & 79,1 \\
\hline P55084 & Trifunctional enzyme subunit beta, mitochondrial OS=Homo sapiens GN=HADHB PE=1 SV=3 - [ECHB_HUMAN] & 72,2 & 63,8 & 85,0 \\
\hline Q9BQA1 & Methylosome protein 50 OS=Homo sapiens GN=WDR77 PE=1 SV=1 - [MEP50_HUMAN] & 81,9 & 72,1 & 66,1 \\
\hline Q15019 & Septin-2 OS=Homo sapiens GN=SEPT2 PE=1 SV=1 - [SEPT2_HUMAN] & 107,3 & 50,0 & 62,2 \\
\hline P23284 & Peptidyl-prolyl cis-trans isomerase B OS=Homo sapiens GN=PPIB PE=1 SV=2 - [PPIB_HUMAN] & 101,3 & 67,5 & 49,7 \\
\hline P00387 & NADH-cytochrome b5 reductase 3 OS=Homo sapiens GN=CYB5R3 PE=1 SV=3 - [NB5R3_HUMAN] & 101,2 & 73,6 & 42,0 \\
\hline P82930 & $28 \mathrm{~S}$ ribosomal protein $\mathrm{S} 34$, mitochondrial $\mathrm{OS}=$ Homo sapiens $\mathrm{GN}=\mathrm{MRPS} 34 \mathrm{PE}=1 \mathrm{SV}=2$ - [RT34_HUMAN] & 49,9 & 79,9 & 84,9 \\
\hline O43795 & Unconventional myosin-Ib OS=Homo sapiens GN=MYO1B PE=2 SV=3 - [MYO1B_HUMAN] & 109,4 & 62,5 & 42,0 \\
\hline O94992 & Protein HEXIM1 OS=Homo sapiens GN=HEXIM1 PE=1 SV=1 - [HEXI1_HUMAN] & 87,1 & 70,5 & 55,6 \\
\hline O75190 & DnaJ homolog subfamily B member 6 OS=Homo sapiens GN=DNAJB6 PE=1 SV=2 - [DNJB6_HUMAN] & 83,1 & 60,9 & 67,9 \\
\hline P16615 & $\begin{array}{l}\text { Sarcoplasmic/endoplasmic reticulum calcium ATPase } 2 \mathrm{OS}=\text { Homo sapiens GN=ATP2A2 PE=1 SV=1 - } \\
\text { [AT2A2_HUMAN] }\end{array}$ & 89,2 & 78,3 & 43,4 \\
\hline Q9NWS0 & PIH1 domain-containing protein $1 \mathrm{OS}=$ Homo sapiens GN=PIH1D1 PE=1 SV=1 - [PIHD1_HUMAN] & 60,1 & 74,7 & 71,0 \\
\hline Q9Y3B9 & RRP15-like protein OS=Homo sapiens GN=RRP15 PE=1 SV=2 - [RRP15_HUMAN] & 56,0 & 78,7 & 69,7 \\
\hline 043242 & 26S proteasome non-ATPase regulatory subunit $3 \mathrm{OS}=$ Homo sapiens $\mathrm{GN}=\mathrm{PSMD} 3 \mathrm{PE}=1 \mathrm{SV}=2-$ [PSMD3_HUMAN] & 81,4 & 63,6 & 59,3 \\
\hline Q9UKD2 & mRNA turnover protein 4 homolog OS=Homo sapiens GN=MRTO4 PE=1 SV=2 - [MRT4_HUMAN] & 75,5 & 50,4 & 77,3 \\
\hline Q9UQE7 & Structural maintenance of chromosomes protein $3 \mathrm{OS}=$ Homo sapiens $\mathrm{GN}=\mathrm{SMC} 3 \mathrm{PE}=1 \mathrm{SV}=2-$ [SMC3_HUMAN] & 82,6 & 67,0 & 53,4 \\
\hline Q9Y3B7 & 39S ribosomal protein L11, mitochondrial OS=Homo sapiens GN=MRPL11 PE=1 SV=1 - [RM11_HUMAN] & 78,4 & 46,1 & 75,5 \\
\hline O94763 & Unconventional prefoldin RPB5 interactor $1 \mathrm{OS}=$ Homo sapiens GN=URI1 PE=1 SV=3 - [RMP_HUMAN] & 42,0 & 90,1 & 66,5 \\
\hline P47756 & F-actin-capping protein subunit beta OS=Homo sapiens GN=CAPZB PE=1 SV=4 - [CAPZB_HUMAN] & 69,1 & 58,3 & 68,2 \\
\hline Q14684 & Ribosomal RNA processing protein 1 homolog B OS=Homo sapiens GN=RRP1B PE $=1 \mathrm{SV}=3$ - [RRP1B_HUMAN] & 76,7 & 44,4 & 71,3 \\
\hline Q9Y4P3 & Transducin beta-like protein $2 \mathrm{OS}=$ Homo sapiens GN=TBL2 PE $=1 \mathrm{SV}=1$ - [TBL2_HUMAN] & 64,3 & 64,2 & 62,2 \\
\hline P52298 & Nuclear cap-binding protein subunit $2 \mathrm{OS}=$ Homo sapiens GN=NCBP2 PE=1 SV=1 - [NCBP2_HUMAN] & 67,8 & 69,3 & 50,1 \\
\hline P08579 & U2 small nuclear ribonucleoprotein B" OS=Homo sapiens GN=SNRPB2 PE=1 SV=1 - [RU2B_HUMAN] & 72,7 & 65,0 & 48,2 \\
\hline P30419 & Glycylp & 71,5 & 48,4 & 62,1 \\
\hline O75569 & $\begin{array}{l}\text { Interferon-inducible double stranded RNA-dependent protein kinase activator A OS=Homo sapiens GN=PRKRA PE } \\
\text { SV=1 - [PRKRA_HUMAN] }\end{array}$ & 66,1 & 46,0 & 69,4 \\
\hline P35250 & Replication factor $\mathrm{C}$ subunit $2 \mathrm{OS}=\mathrm{Homo}$ sapiens $\mathrm{GN}=\mathrm{RFC} 2 \mathrm{PE}=1 \mathrm{SV}=3-\left[\mathrm{RFC} 2 \_\mathrm{HUMAN}\right]$ & 74,6 & 41,7 & 63,1 \\
\hline Q9NVA2 & Septin-11 OS=Homo sapiens GN=SEPT11 PE=1 SV=3 - [SEP11_HUMAN] & 62,4 & 51,1 & 61,5 \\
\hline O00469 & Procollagen-lysine,2-oxoglutarate 5-dioxygenase $2 \mathrm{OS}=$ Homo sapiens GN=PLOD2 PE=1 SV=2 - [PLOD2_HUMAN] & 61,6 & 60,4 & 46,7 \\
\hline
\end{tabular}


Table S3. List of primers. These primers were used to amplify the ORFs of the genes encoding LGP2, RIGI, MDA5, and PACT and their fragments for cloning using the Gateway approach used for the PCA.

\begin{tabular}{|l|l|l|}
\hline Gene & Forward primer & Reverse primer \\
\hline LGP2 & ggggacaactttgtacaaaaaagttggCATGGAGCTTCGGTCCTACC & ggggacaactttgtacaagaaagttggTTAGTCCAGGGAGAGGTCCG \\
\hline LCTD & ggggacaactttgtacaaaaaagttggcGTATACGCGTTTGTAGCAACTGAAGG & ggggacaactttgtacaagaaagttggTTAGTCCAGGGAGAGGTCCG \\
\hline RIG-I & ggggacaactttgtacaaaaaagttggcATGACCACCGAGCAGCGACGC & ggggacaactttgtacaagaaagttggTTATTTGGACATTTCTGCTGG \\
\hline RCTD & ggggacaactttgtacaaaaaagttggcGGTAGCAAGTGCTTCCTTCTGAC & ggggacaactttgtacaagaaagttggTTATTTGGACATTTCTGCTGG \\
\hline MDA5 & $\begin{array}{l}\text { ggggacaactttgtacaaaaaagttggCATGTCGAATGGGTTTCCACAGACGA } \\
\text { G }\end{array}$ & ggggacaactttgtacaagaaagttggTTCTAATCCTCATCACTAAATAAAC \\
\hline PACT & ggggacaactttgtacaaaaaagttggCATGTCCCAGAGCAGGCACCGCGCCG & ggggacaactttgtacaagaaagttggTTACTTTCTTTCTGCTATTATC \\
\hline
\end{tabular}

